\author{
Part of Journal of Research of the National Bureau of Standards, Volume 19, \\ October 1937
}

\title{
STUDY OF TRANSPARENT PLASTICS FOR USE ON AIRCRAFT
}

\author{
By Benjamin M. Axilrod and Gordon M. Kline
}

\begin{abstract}
Various transparent organic plastics, including both commercially available and experimental materials, were examined to determine their suitability for use as flexible windshields on aircraft. The properties studied include light transmission, haziness, distortion of vision, resistance to weathering, scratch resistance, indentation hardness, impact strength, dimensional stability, resistance to water and various cleaning fluids, bursting strength at normal and low temperatures, and flammability.
\end{abstract}

The two types of transparent plastics which are now in use on aircraft-namely, cellulose acetate and acrylate resin-were found to have certain defects which, it is believed, can be overcome in part by suitable modification of the composition and processing of the plastic.

Cellulose acetate plastic was found to have excellent impact strength, bursting strength, and flexibility, but the commercial products tested varied considerably in resistance to weathering and were all subject to marked shrinkage in 1 year's time. The shrinkage produces warping and sets up strains in the plastic sheets, which cause them to craze and crack. These strains are believed to be the cause of the spontaneous cracking of cellulose acetate windshields after they have been in service for 6 months or longer. This is particularly true of windshields exposed to low temperatures, as by ascent to high altitudes, thereby introducing additional strains in the windshield because of thermal contraction. A great deal of variation was observed in the weathering resistance between cellulose acetate sheets received from different manufacturers, and also between different lots of the material from the same manufacturer.

The acrylate resin plastic was found to be remarkably transparent, more stable to light and weathering and more resistant to scratching than cellulose acetate, but its impact strength and flexibility are much poorer. Surface crazing of the acrylate resins was noted after 1 year's exposure on the roof and also after storage for a similar period. It is claimed, however, that a method of processing has been developed which eliminates this tendency to craze. Further tests on modified samples of both cellulose acetate and acrylate resins are in progress to determine whether more uniformly durable products than have been on the market to date can be made available to the aircraft industry.

Other transparent plastics, such as cellulose nitrate, ethylcellulose, vinyl chloride-acetate resin, and vinyl acetal resins, failed in resistance to weathering after approximately 3 months. Glyceryl-phthalate, styrene, and phenol-formaldehyde resin plastics discolored markedly on exposure to sunlight or ultraviolet light from a carbon-arc lamp, and were also lacking in the flexibility which is desirable for aircraft windshields. A sample of cellulose acetobutyrate was practically unchanged after 12 months' exposure. With the exception of the cellulose nitrate, cellulose acetate, and acrylate resin plastics, the materials tested were of an experimental nature and were not recommended for use on aircraft. Many of the undesirable properties observed for these experimental materials will undoubtedly be eliminated in the course of the development of these plastics and it is not improbable that some of them will later become available in a form suitable for windshield use. 
I. Introduction -368

II. Clarity _.. 369

1. Description of hazeometer

2. Test procedure and definitions

3. Results of measurements of clarity

(a) Light transmission_....................... 372

(b) Haziness . . . . .

III. Index of refraction

IV. Visibility distortion tests on plastics_._.

V. Resistance to weathering

VI. Accelerated aging

VII. Scratch resistance

1. Description of apparatus

2. Results of scratch-width measurements _.

VIII. Indentation hardness _...

IX. Impact strength

1. Charpy test.

2. Falling-ball test_...

X. Shrinkage $\ldots \ldots \ldots$

XI. Resistance to water, alcohol, and kerosene

XII. Bursting strength.

XIII. Flammability _

XIV. Conclusion_... 400

\section{INTRODUCTION}

Although no organic plastic has yet been developed that has the scratch resistance and low price of glass, nevertheless, plastic materials are now widely used as windows on airplanes. Two important properties of the plastics-namely, light weight and flexibility-have brought about this invasion of a field previously limited to glass. The organic plastics are approximately one-half as heavy as glass, a distinct advantage for aeronautical purposes. Flexibility is desirable in order to permit the use of curved transparent inclosures which offer minimum wind resistance.

The plastic sheets used in this country for aircraft windows (fig. 1) are made from cellulose acetate, known commercially under such trade names as Fibestos, Lumarith, and Plastacele, or from polymerized esters of acrylic and methacrylic acids, designated in the trade as Lucite and Plexiglas. Cellulose nitrate transparent sheeting is also employed to a limited extent; this type of product is variously designated as Celluloid, Fiberloid, Pryalin, and the like, by its manufacturers. A transparent synthetic resin made from glycerol and phthalic anhydride has been used in England as a window material on aircraft, but this product is not as flexible as the cellulose derivatives. None of the organic plastics possesses the surface hardness typical of glass, and the abrasive action of sand, dust, dirty rags, and flying insects soon impairs their transparency. For this reason a laminated product, made by sandwiching a plastic material between two layers of glass and commonly called safety glass, is used in locations where clear and undistorted vision is demanded, as through the windshield directly in front of the pilot. These parts must be designed for flat pieces, however, since the commercial production of laminated glass in curved shapes is very difficult to achieve and costly, although it has been accomplished experimentally.

Although the cellulose acetate sheets are more satisfactory with respect to weathering than the nitrate product, they are very suscep- 


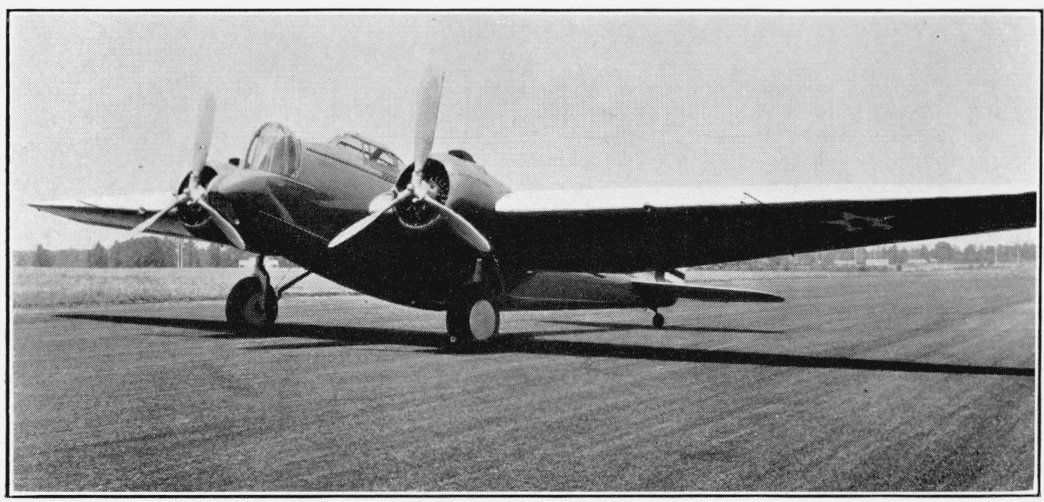

FiguRE 1.-Transparent plastic covering on turret and cockpit of a bomber.

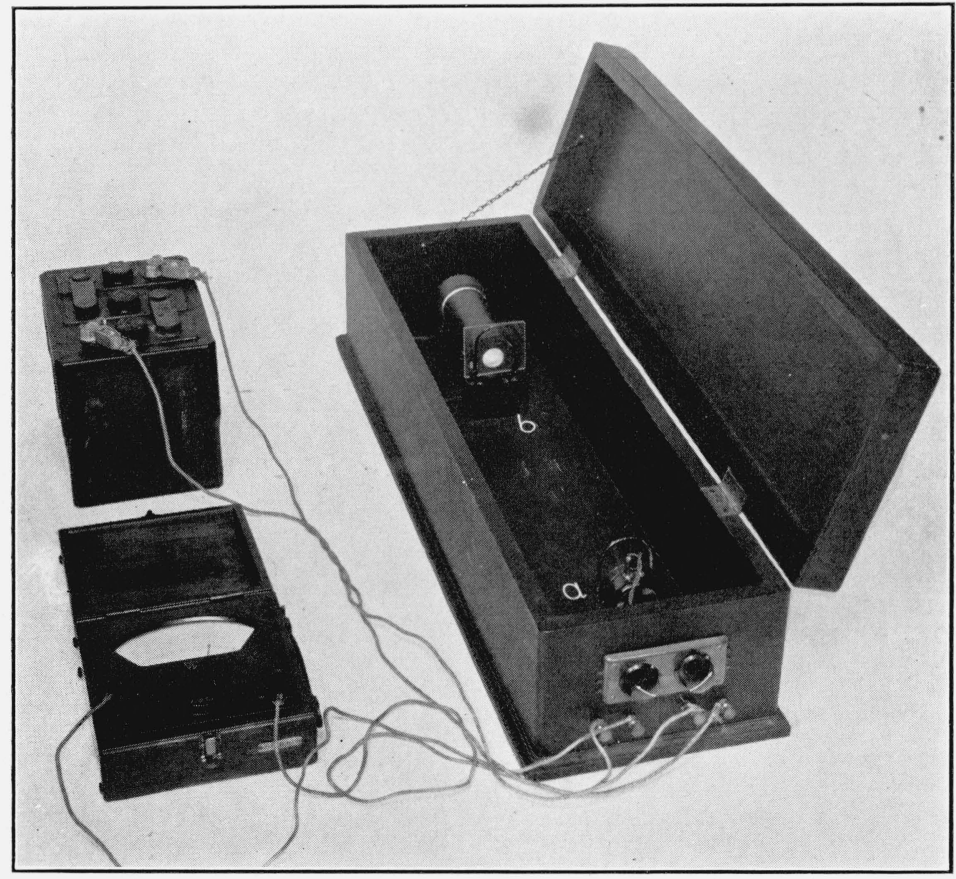

Figure 2.-Hazeometer. 
tible to scratching and have been observed to develop a surface cracking after a few months in service. These factors lead to an impairment of vision through such material. Recognizing the need for an improved flexible material for use in curved windows on aircraft, the National Advisory Committee for Aeronautics established a project at the National Bureau of Standards to study the available transparent plastics with regard to their suitability for this purpose.

The following types of transparent plastics were found to be available commercially or experimentally for examination in connection with our investigation: Cellulose nitrate, cellulose acetate, cellulose acetobutyrate, ethylcellulose, acrylate (which term is used to include the polymerized esters of both acrylic and methacrylic acids), vinyl chloride-acetate, vinyl acetal, glyceryl-phthalate, styrene, and phenolformaldehyde. Laminated glass for use on aircraft is made at the present time with four different plastic materials, as bindersnamely, cellulose nitrate, cellulose acetate, acrylate resin, and vinyl acetal resin. Samples of these various products were obtained for investigation through the courtesy of the respective manufacturers.

The properties of transparent plastics of primary importance in their use for aircraft are as follows: Light transmission, freedom from haze, surface imperfections and constituents which reduce or distort vision, resistance to weathering, resistance to surface abrasion, impact strength, dimensional stability, resistance to the action of water and cleaning fluids, bursting strength at normal and low temperatures, and flammability.

\section{CLARITY}

The clarity of plastics is generally considered to be dependent upon two factors, light transmission and scattering of light by particles or by surface imperfections. Distortion caused by wavy surfaces and nonhomogeneous material is also an important factor in visibility through windshield materials and will be considered in section IV of this paper. The military services until recently specified that the plastic sheet should transmit at least 68 percent of white light when tested within 30 days of the date of manufacture and should be free from wrinkles, bubbles, scratches, pits, or depressions. The light transmission is usually measured with a visual or photoelectric photometer, employing in the latter a photoelectric cell which is sensitive mainly to the visible portion of the spectrum. The transparent plastics now in use generally transmit more than 85 percent of the incident light. The haziness has been measured by several methods, including visual inspection with or without a background of light from Cooper-Hewitt lamps, comparison of the plastic specimen with graded samples of varying degrees of haziness, counting the "star dust" visible in a small area under the microscope, and the determination of a small portion of the light scattered when the sample is placed at a suitable angle with relation to the light source and photometer. Although the latter method has the desirable feature of utilizing one instrument for measuring both light transmission and haziness, there is the possibility of introducing considerable error since only a small portion of the scattered light is measured.

A photometer of simple construction, called the "hazeometer", which can be used effectively to measure the haziness of a plastic as well as the light transmission, was developed in the course of this investigation. 


\section{DESCRIPTION OF HAZEOMETER}

The apparatus is shown in figure 2. A 6-volt automobile-type bulb is mounted in front of a reflector. A cylindrical shield, blackened inside and with a circular aperture $b$ in the center of the base, causes an approximately parallel beam of light to be radiated toward the photoelectric cell. A blackened disk with a circular aperture, $a$, is mounted in front of the photoelectric cell. In the instrument as built for experimental purposes the two openings, $a$ and $b$, are each 1 inch in diameter and are spaced 18 inches apart. The photoelectric cell is of the Weston photronic type. The spectral response of this cell deviates considerably from the luminosity curve of the eye, and hence the light transmission obtained is not the same as would be measured with a visual photometer but is a close approximation to such value for samples containing little or no dye. A filter can be obtained from the manufacturer which will approximately correct the response of the cell to that of the eye. The meter has an internal resistance of $50 \mathrm{ohms}$ and a range of 100 microamperes. Spring clamps are fastened to the frame at each aperture to hold the plastic in place. A 6-volt storage battery is used to operate the lamp. All the parts are housed within a wooden box finished in a dull black which reduces reflections to a minimum. The lid of the box is closed during measurements to keep rays of light from outside sources from reaching the photoelectric cell. This instrument is only applicable for measuring the haze in sheets which have approximately parallel surfaces and are free from imperfections which act as lenses or prisms.

\section{TEST PROCEDURE AND}

To obtain a measure of the light transmission of the plastic, the light is adjusted in intensity so that a current of 100 microamperes is obtained from the photoelectric cell. A flat sample is then placed in front of the cell at aperture $a$. Of the light incident on the sample, a fraction is transmitted undeviated, and a fraction is scattered by the surfaces and the interior of the sample. The photoelectric cell receives the undeviated fraction of the light and that part of the scattered light which is not deflected at angles greater than about $90^{\circ}$. The light transmission of the plastic is defined as that fraction of the light received by the photoelectric cell through the unobstructed aperture, which continues to reach the sensitive element when the plastic is placed over the aperture $a$ directly in front of the photoelectric cell.

To obtain a measure of the haziness the specimen is placed at aperture $b, 18$ inches distant from aperture $a$. The photoelectric cell still receives the undeviated fraction of the light, but collects only that small portion of the scattered light which is confined to the small solid angles subtended by aperture $a$ at points in opening $b$. The difference between the photoelectric currents with the sample at $a$ and $b$ is a measure of the light scattered, assuming that a linear relation exists between the photoelectric current and the total light incident upon the sensitive element of the cell. The current is practically proportional to the total incident light for no external resistance; the deviation is only slight for the $50-0 h m$ resistance in the microammeter used. Haziness is defined as the percentage of the total light transmitted at position $a$, which is scattered when the sample is placed at position $b$. 


\section{RESULTS OF MEASUREMENTS OF CLARITY}

The initial white-light transmission and haziness of the materials submitted by cooperating manufacturers were measured with the hazeometer. The results are presented in table 1. Each value in the table is the average for three specimens, each $1 \frac{11}{4}$ by $2 \frac{1}{2}$ inches. The results of measurements of light transmission and haziness on several varieties of plain and laminated glass are given in table 2 for comparison.

TABLE 1.-Optical properties of transparent plastics

\begin{tabular}{|c|c|c|c|c|c|}
\hline Material & Sample & $\begin{array}{c}\text { Thick- } \\
\text { ness }\end{array}$ & $\begin{array}{l}\text { White- } \\
\text { light } \\
\text { trans- } \\
\text { mission }\end{array}$ & $\begin{array}{l}\text { Haze } \\
\text { value }\end{array}$ & $\begin{array}{l}\text { Index of } \\
\text { refrac- } \\
\text { tion }\end{array}$ \\
\hline $\begin{array}{l}\text { Cellulose acetate } \\
\text { Do } \\
\text { Do } \\
\text { Do } \\
\text { Do } \\
\text { Do } \\
\text { Do } \\
\text { Do } \\
\text { Do } \\
\text { Do } \\
\text { Do }\end{array}$ & $\begin{array}{l}A 1 \\
A 2 \\
A 3 \\
B 1 \\
B 2 \\
B 3 \\
B 4 \\
B 5 \\
C 1 \\
C 3 \\
D 1\end{array}$ & $\begin{array}{r}\text { Mils } \\
64 \\
95 \\
133 \\
63 \\
93 \\
64 \\
98 \\
101 \\
56 \\
125 \\
162\end{array}$ & $\begin{array}{r}\text { Percent } \\
88.8 \\
8.9 \\
83.0 \\
91.4 \\
90.6 \\
91.7 \\
89.1 \\
88.7 \\
88.2 \\
81.8 \\
77.1\end{array}$ & $\begin{array}{r}\text { Percent } \\
3.9 \\
6.1 \\
7.6 \\
7.1 \\
5.1 \\
4.0 \\
4.0 \\
3.9 \\
6.1 \\
10.4 \\
6.7\end{array}$ & $\begin{array}{l}n_{D}^{21} \\
1.500 \\
1,500 \\
\text { 1. } 501 \\
\text { 1. } 501 \\
\text { 1. } 502 \\
1.500 \\
\text { 1. } 495 \\
1.498 \\
1.500 \\
\text { 1. } 501 \\
1.475\end{array}$ \\
\hline Cellulose acetobutyrate.-... & S1 & 41 & 92.3 & 6.0 & 1. 494 \\
\hline $\begin{array}{l}\text { Cellulose nitrate.............. } \\
\text { Do }\end{array}$ & $\begin{array}{l}E 1 \\
F 1\end{array}$ & $\begin{array}{l}67 \\
64\end{array}$ & $\begin{array}{l}91.6 \\
85.0\end{array}$ & $\begin{array}{l}3.7 \\
4.1\end{array}$ & $\begin{array}{l}\text { 1. } 501 \\
\text { 1. } 501\end{array}$ \\
\hline $\begin{array}{l}\text { Ethylcellulose } \\
\text { Do } \\
\text { Do }\end{array}$ & $\begin{array}{l}\text { G1 } \\
\text { H1 } \\
\text { I1 }\end{array}$ & $\begin{array}{l}57 \\
29 \\
38\end{array}$ & $\begin{array}{l}82.1 \\
86.1 \\
91.1\end{array}$ & $\begin{array}{r}27.2 \\
9.8 \\
7.0\end{array}$ & $\begin{array}{l}1.479 \\
1.472 \\
1.483\end{array}$ \\
\hline $\begin{array}{l}\text { Acrylate resin } \\
\text { Do } \\
\text { Do } \\
\text { Do }\end{array}$ & $\begin{array}{l}\mathrm{J} 1 \\
\mathrm{~J} 2 \\
K 1 \\
K 2\end{array}$ & $\begin{array}{r}66 \\
76 \\
117 \\
88\end{array}$ & $\begin{array}{l}93.6 \\
93.7 \\
94.1 \\
94.2\end{array}$ & $\begin{array}{l}4.6 \\
4.2 \\
1.9 \\
1.8\end{array}$ & $\begin{array}{l}1.496 \\
1.492 \\
1.496 \\
1.483\end{array}$ \\
\hline $\begin{array}{l}\text { Vinyl chloride-acetate resin } \\
\text { D }\end{array}$ & $\begin{array}{l}L 1 \\
L 2\end{array}$ & $\begin{array}{r}56 \\
100\end{array}$ & $\begin{array}{l}82.5 \\
79.2\end{array}$ & $\begin{array}{l}5.3 \\
7.2\end{array}$ & $\begin{array}{l}1.525 \\
1.529\end{array}$ \\
\hline Vinyl acetal resin & $\begin{array}{l}M 1 \\
N 1\end{array}$ & $\begin{array}{r}62 \\
126\end{array}$ & $\begin{array}{l}88.8 \\
84.4\end{array}$ & $\begin{array}{r}5.4 \\
11.5\end{array}$ & $\begin{array}{l}\text { 1. } 509 \\
1.490\end{array}$ \\
\hline Glyceryl-phthalate resin... & $P 1$ & 159 & 86.2 & 4.8 & 1. 578 \\
\hline
\end{tabular}

TABLE 2.-Optical properties of glass windshield products

\begin{tabular}{|c|c|c|c|c|c|}
\hline Type of glass & $\begin{array}{l}\text { Type of plastic } \\
\text { lamination }\end{array}$ & Sample & $\begin{array}{l}\text { Thick- } \\
\text { ness }\end{array}$ & $\begin{array}{l}\text { White-light } \\
\text { transmis- } \\
\text { sion }\end{array}$ & $\begin{array}{l}\text { Haze } \\
\text { value }\end{array}$ \\
\hline $\begin{array}{l}\text { Thin plate } \\
\text { Thin plate safety. } \\
10-0 z \text { sheet } \\
10-0 z \text { sheet safety. } \\
1 / 4 \text {-inch plate }\end{array}$ & $\begin{array}{l}\text { None } \\
\text { Acetate... } \\
\text { None } \\
\text { Acetate. } \\
\text { None }\end{array}$ & $\begin{array}{l}X 1 \\
X 5 \\
X 2 \\
X 6 \\
X_{4}\end{array}$ & $\begin{array}{r}\text { Mils } \\
85 \\
186 \\
53 \\
130 \\
225\end{array}$ & $\begin{array}{r}\text { Percent } \\
\text { \&86. } \\
\text { a82. } \\
93.2 \\
91.3 \\
91.0\end{array}$ & $\begin{array}{r}\text { Percent } \\
0.9 \\
1.3 \\
1.2 \\
1.2 \\
0.9\end{array}$ \\
\hline $\begin{array}{l}\text { Thin sheet safety } \\
\text { Do } \\
\text { Plate safety }\end{array}$ & Acrylate............ & $\begin{array}{l}Y 1 \\
Y 2 \\
Y 3\end{array}$ & $\begin{array}{l}107 \\
130 \\
248\end{array}$ & $\begin{array}{l}92.8 \\
92.4 \\
89.4\end{array}$ & $\begin{array}{l}1.2 \\
1.2 \\
1.2\end{array}$ \\
\hline $\begin{array}{l}\text { Plate safety } \\
\text { Do } \\
\text { Sheet safety }\end{array}$ & $\begin{array}{l}\text { Nitrate } \\
\text { Vinyl-................... }\end{array}$ & $\begin{array}{l}Z 1 \\
Z 2 \\
Z 3\end{array}$ & $\begin{array}{l}234 \\
261 \\
144\end{array}$ & $\begin{array}{r}873.7 \\
871.6 \\
92.0\end{array}$ & $\begin{array}{l}1.8 \\
1.4 \\
1.6\end{array}$ \\
\hline
\end{tabular}

* These glasses distinctly colored, probably by iron oxide. 


\section{(a) LIGHT TRANSMISSION}

It will be noted that the white-light transmission of all of the plastics tested exceeds the 68-percent requirement formerly specified by the military services. The highest values were obtained with samples of acrylate resins, the percentage transmission varying between 93.6 and 94.2 for these materials. The samples of cellulose acetate which gave white-light transmissions exceeding 90 percent did not contain blue dye, whereas those tinted blue gave values varying between 77 and 83 percent. The effect of the addition of blue coloring on the transmissivity is shown in table 2 for the glass products and in table 3 for a special series of cellulose acetate transparent plastics. Because of the pronounced lowering of the percentage of light transmitted, the practice of adding blue dye to cellulose acetate transparent sheet has been discontinued by some manufacturers. For undyed materials approaching the transparency of polished glass, most of the loss of light is due to reflection at the two surfaces and can be approximately calculated from the refractive index.

TABLE 3.-Light-transmission and haziness values of transparent cellulose acetate plastics with and without the addition of blue dye

\begin{tabular}{|c|c|c|c|c|}
\hline \multirow[b]{2}{*}{ Thickness } & \multirow[b]{2}{*}{ Dye } & \multicolumn{2}{|c|}{ Light-transmission } & \multirow[b]{2}{*}{$\begin{array}{c}\begin{array}{c}\text { Haziness } \\
\text { value }\end{array} \\
\left(\frac{A-B}{A} 100\right)\end{array}$} \\
\hline & & $\begin{array}{l}\text { Sample at } \\
\text { photo-- } \\
\text { electric } \\
\text { cell } \\
(A)\end{array}$ & $\begin{array}{l}\text { Sample 18 } \\
\text { in. from } \\
\text { photo- } \\
\text { electric } \\
\text { cell } \\
(B)\end{array}$ & \\
\hline 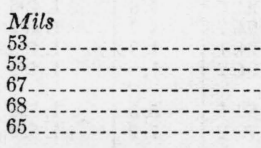 & 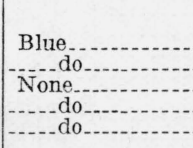 & $\begin{array}{r}\text { Percent } \\
86.3 \\
86.2 \\
90.7 \\
91.2 \\
91.0\end{array}$ & $\begin{array}{r}\text { Percent } \\
83.9 \\
83.7 \\
87.6 \\
87.5 \\
85.8\end{array}$ & $\begin{array}{r}\text { Percent } \\
2.8 \\
2.9 \\
3.4 \\
4.1 \\
5.7\end{array}$ \\
\hline $\begin{array}{l}67 \\
67 \\
85 \\
31 \\
35\end{array}$ & \begin{tabular}{|c|} 
do do \\
Blue
\end{tabular} & $\begin{array}{l}90.7 \\
90.7 \\
89.7 \\
4.2 \\
86.7\end{array}$ & $\begin{array}{r}85.3 \\
85.2 \\
84.0 \\
3.8 \\
78.4\end{array}$ & $\begin{array}{l}6.0 \\
6.1 \\
6.4 \\
9.0 \\
9.6\end{array}$ \\
\hline $\begin{array}{l}35 \\
105 \\
105\end{array}$ & \begin{tabular}{|c|} 
\\
\hdashline do
\end{tabular} & $\begin{array}{l}86.7 \\
75.0 \\
75.1\end{array}$ & $\begin{array}{l}77.6 \\
64.3 \\
63.8\end{array}$ & $\begin{array}{l}10.5 \\
14.3 \\
15.0\end{array}$ \\
\hline
\end{tabular}

(b) HAZINESS

The haze values for two of the acrylate samples, namely, 1.8 and 1.9 percent, compare favorably with measurements made on laminated safety glass and are the lowest of any of the plastics studied. The values for the cellulose acetate products show considerable variation. Apparently a minimum of about 4 percent of haze for sheets up to 100 mils thick is the best that can be done and for thicker sheets this would be somewhat higher. The fog or cloudiness in sheets with haze values of this order is quite easily detected by the naked eye and is a much more serious defect than the lowering of white-light transmission by blue dye. The values recorded in table 1 for the materials other than cellulose nitrate, cellulose acetate, and acrylate resin, were obtained on experimental samples only, such products not being available in sheet form for aircraft windshields at the present time. 


\section{INDEX OF REFRACTION}

The index of refraction is of interest in considering the light-transmission characteristics of plastics. This property was measured by means of an Abbe refractometer on the same specimens used in the light-transmission and haze tests. Two contact liquids, alphabromonaphthalene and mercuric iodide, were employed in order to guard against incorrect values resulting from reaction between the sample and the contact liquid. The data obtained are presented in table 1. The refractive indices for the materials studied range from 1.47 to 1.58 .

\section{VISIBILITY DISTORTION TESTS ON PLASTICS}

Visibility distortion tests were made in accordance with the procedure suggested by the American Standards Association for laminated safety glass using sheets 12 inches square. In this test, a line is projected with a lantern so as to fall midway between two parallel lines 1 inch apart marked on a screen. The test specimen is 25 feet from the screen and the lantern is adjusted so that the center 10- by 10-inch square fills the beam. The sample in a suitable frame is moved across the beam and the movement of the projected line observed; the safetyglass specification requires that the projected line shall not deviate more than $1 / 2$ inch as the sheet is moved across the beam. Several materials were tested but none failed to meet the specification. Measurements were then made on each sample of the deviation of the projected line as the square was moved an inch at a time across the beam. This measurement was made at the top, center, and bottom of the screen for the sample normal to the incident light; this was repeated just at the center of the screen for angles of $75,60,45$, and $30^{\circ}$. The data did not prove suitable for giving an estimate of the visibility because a specimen with many relatively small ripples simply causes the projected line to move back and forth rapidly as well as causing it to get out of focus; a sample which is slightly wedgeshaped or one with a large wave in its surface might cause the line to deviate as much or more, yet it would be far superior as regards distortion.

The above considerations led to the following method for evaluating the distortion of the transparent plastic sheets. A projection lantern is focused on a screen 40 feet distant; the specimen is placed in front of and parallel to the screen. The sample is moved toward the light and its shadow observed. When light and dark patches begin to appear in the shadow, the distance of the specimen from the screen is noted and is taken as a measure of the relative distorting characteristics of the sheet. The less distortion, the greater is the distance at which the shadow becomes nonuniform. Observations were made by three individuals on 12 - by 12 -inch samples of the plastics. The averages of these observations are shown in table 4 . The acrylate resin sheets are found to be considerably better than other plastic materials in this test. 
TABLE 4.-Measurements of distortion of light by transparent plastics

\begin{tabular}{|c|c|c|}
\hline Material & Sample & $\begin{array}{l}\text { Distance } \\
\text { where } \\
\text { shadow } \\
\text { becomes } \\
\text { spotty }\end{array}$ \\
\hline Acrylate resin & & $\begin{array}{l}\text { Inches } \\
26\end{array}$ \\
\hline $\begin{array}{l}\text { Vinyl chloride-acetate resin } \\
\text { Cellulose nitrate- }\end{array}$ & Li & 11 \\
\hline $\begin{array}{l}\text { Cellulose nitrate- } \\
\text { Cellulose acetate-..... }\end{array}$ & $F 1$ & 7 \\
\hline $\begin{array}{l}\text { Cellulose acetate- } \\
\text { Vinyl acetal resin- }\end{array}$ & $A 2$ & $\begin{array}{l}5 \\
4\end{array}$ \\
\hline $\begin{array}{l}\text { Vinyl acetal resin } \\
\text { Cellulose acetate-o- }\end{array}$ & ${ }_{C Q}^{N I}$ & $\begin{array}{l}4 \\
4\end{array}$ \\
\hline $\begin{array}{l}\text { Cellulose acetate- } \\
\text { Do }\end{array}$ & ${ }_{B \gamma}^{C 2}$ & ${ }_{2}^{4}$ \\
\hline Do & $D 1$ & 0.5 \\
\hline
\end{tabular}

\section{RESISTANCE TO WEATHERING}

Specimens of transparent plastics 7 by 7 inches were prepared for weather-exposure tests by fastening them in brass frames curved cylindrically to a radius of 5 inches. Most of the materials were flexible enough to bend to the curvature of the frame without special heat treatment and could be drilled in the flexed position without cracks forming at the holes. Two samples of the acrylate resin sheets, J2 and $K 1$, were softened in water warmed to about $60^{\circ} \mathrm{C}$ for 15 minutes and then bent and drilled. Another acrylate sample, $K 3$, was softened by heating for 10 minutes at $70^{\circ} \mathrm{C}$ in an oven. One manufacturer of these resinous sheets has recently recommended bending them by warming at 90 to $125^{\circ} \mathrm{C}$, depending on the thickness, using as the heating medium either water or preferably, hot air, pressing the sheet around a wood or metal form covered with rubber or glove cloth, and allowing it to cool in the bent position. Determinations of initial white light transmission and haze were made on the specimens in the frames before placing them on the roof. In addition, the light transmission was measured with red, green, and blue filters in order to follow any color changes in the various materials during exposure. The frames were fastened to exposure racks on the roof of the Industrial Building of the National Bureau of Standards, the racks facing south and being inclined at an angle of $45^{\circ}$ to the horizontal. The tests were started on the roof during March 1936, and the changes in clarity after $1,2,3,6,9$, and 12 months were determined quantitatively. The specimens were cleaned with lens paper soaked in tap water, and for some of the materials in kerosene, prior to each measurement of their clarity.

The data for light transmission and haze made on the transparent plastics are given in tables 5,6 , and 7 . 
TABLE 5.-Effect of outside exposure on white-light transmission

\begin{tabular}{|c|c|c|c|c|c|c|c|}
\hline \multirow{2}{*}{ Material } & \multirow{2}{*}{$\begin{array}{c}\text { Sam- } \\
\text { ple }\end{array}$} & \multicolumn{5}{|c|}{ Light transmission } & \multirow{2}{*}{$\begin{array}{l}\text { Remarks on condition at } \\
\text { last test period }\end{array}$} \\
\hline & & Initial & 3 months & 6 months & 9 months & $\begin{array}{c}12 \\
\text { months }\end{array}$ & \\
\hline $\begin{array}{l}\text { Cellulose acetate..... } \\
\text { Do._. } \\
\text { Do.-. } \\
\text { Do }\end{array}$ & $\begin{array}{l}A 1 \\
A 2 \\
A 3 \\
B 1\end{array}$ & $\begin{array}{r}\text { Percent } \\
88.2 \\
85.2 \\
82.2 \\
90.8\end{array}$ & $\begin{array}{r}\text { Percent } \\
90.6 \\
88.2 \\
86.4 \\
91.6\end{array}$ & $\begin{array}{r}\text { Percent } \\
83.4 \\
81.7 \\
84.9 \\
91.2\end{array}$ & $\begin{array}{r}\text { Percent } \\
85.5 \\
81.2 \\
83.5 \\
91.3\end{array}$ & $\begin{array}{r}\text { Percent } \\
77.1 \\
71.1 \\
72.9 \\
91.3\end{array}$ & $\begin{array}{l}\text { Crazed; discolored. } \\
\text { Do. } \\
\text { Do. } \\
\text { Surface r o u g h e n ed; } \\
\text { cracked. }\end{array}$ \\
\hline $\begin{array}{l}\text { Do } \\
\text { Do } \\
\text { Do } \\
\text { Do } \\
\text { Do }\end{array}$ & $\begin{array}{l}B 2 \\
B 3 \\
C 1 \\
C 2 \\
D 1\end{array}$ & $\begin{array}{l}89.9 \\
90.7 \\
87.1 \\
81.1 \\
76.6\end{array}$ & $\begin{array}{l}90.7 \\
90.7 \\
87.6 \\
83.1 \\
87.9\end{array}$ & $\begin{array}{l}90.5 \\
90.5 \\
88.7 \\
83.5 \\
86.7\end{array}$ & $\begin{array}{l}90.7 \\
90.4 \\
89.2 \\
84.7 \\
80.9\end{array}$ & $\begin{array}{l}90.7 \\
88.8 \\
89.3 \\
84.6 \\
57.4\end{array}$ & $\begin{array}{l}\text { Do. } \\
\text { Crazed. } \\
\text { Pebbled; crazed at edge. } \\
\text { Do. } \\
\text { Crazed and cracked. }\end{array}$ \\
\hline Cellulose acetobutyrate & S1 & 92.0 & 92.2 & 92.2 & 92.1 & 92.2 & Unchanged. \\
\hline $\begin{array}{l}\text { Cellulose nitrate } \\
\text { Do }\end{array}$ & $\begin{array}{l}E 1 \\
F 1\end{array}$ & $\begin{array}{l}91.0 \\
83.7\end{array}$ & $\begin{array}{l}84.8 \\
79.1\end{array}$ & $\begin{array}{l}43.2 \\
39.0\end{array}$ & $\begin{array}{l}37.0 \\
34.2\end{array}$ & $\begin{array}{l}35.1 \\
32.2\end{array}$ & $\begin{array}{l}\text { Surface crazed; opaque. } \\
\text { Do. }\end{array}$ \\
\hline $\begin{array}{l}\text { Ethylcellulose } \\
\text { Do }\end{array}$ & $\begin{array}{l}G 1 \\
H 1\end{array}$ & $\begin{array}{l}79.7 \\
85.3\end{array}$ & $\begin{array}{l}51.8 \\
86.2\end{array}$ & & & & Opaque; cracked. \\
\hline Do.............. & $I 1$ & 90.3 & 89.8 & 60.2 & 24.0 & & Opaque; friable. \\
\hline $\begin{array}{l}\text { Acrylate resin } \\
\text { Do } \\
\text { Do } 0 \text { - } \\
\text { Do } 0 . \\
\text { Do }\end{array}$ & $\begin{array}{l}J 1 \\
J 2 \\
K 1 \\
K 2 \\
K 3\end{array}$ & $\begin{array}{l}92.9 \\
93.2 \\
93.3 \\
93.2 \\
93.5\end{array}$ & $\begin{array}{l}92.7 \\
93.0 \\
92.7 \\
93.7 \\
93.5\end{array}$ & $\begin{array}{l}92.9 \\
93.1 \\
91.7 \\
93.6 \\
93.3\end{array}$ & $\begin{array}{l}92.6 \\
92.8 \\
91.7 \\
93.5 \\
92.6\end{array}$ & $\begin{array}{l}92.3 \\
92.6 \\
91.4 \\
93.1 \\
-\end{array}$ & $\begin{array}{l}\text { Roughened; crazed. } \\
\text { Crazed. } \\
\text { Slightly discolored. } \\
\text { Roughened; crazed. } \\
\text { Slight crazing. }\end{array}$ \\
\hline $\begin{array}{l}\text { Vinyl chloride-acetate } \\
\text { resin } \\
\text { Doo }\end{array}$ & $\begin{array}{l}L 1 \\
L 2\end{array}$ & $\begin{array}{l}81.6 \\
78.9\end{array}$ & $\begin{array}{l}77.4 \\
70.2\end{array}$ & $\begin{array}{r}30.0 \\
4.1\end{array}$ & $\begin{array}{r}33.4 \\
3.9\end{array}$ & $\begin{array}{r}36.0 \\
4.4\end{array}$ & $\begin{array}{l}\text { Discolored; crazed. } \\
\text { Discolored; opaque. }\end{array}$ \\
\hline $\begin{array}{l}\text { Vinyl acetal resin... } \\
\text { Do }\end{array}$ & $\begin{array}{l}M 1 \\
N 1\end{array}$ & $\begin{array}{l}88.0 \\
84.3\end{array}$ & $\begin{array}{l}87.1 \\
69.4\end{array}$ & $\begin{array}{l}78.7 \\
53.6\end{array}$ & $\begin{array}{l}57.1 \\
43.8\end{array}$ & 52.3 & $\begin{array}{l}\text { Crazed; opaque. } \\
\text { Do. }\end{array}$ \\
\hline Glyceryl-phthalateresin. & 01 & 85.5 & & 82.8 & 82.4 & & Slightly discolored. \\
\hline
\end{tabular}


TABLE 6.-Effect of outdoor exposure of transparent plastics on light transmission using various color filters

\begin{tabular}{|c|c|c|c|c|c|c|c|c|c|c|c|c|c|}
\hline \multirow[b]{3}{*}{ Material } & \multirow[b]{3}{*}{$\begin{array}{c}\text { Sam- } \\
\text { ple }\end{array}$} & \multicolumn{12}{|c|}{ Color transmission } \\
\hline & & \multicolumn{4}{|c|}{ Red filter s } & \multicolumn{4}{|c|}{ Green filter b } & \multicolumn{4}{|c|}{ Blue filter $\circ$} \\
\hline & & 㞼 & 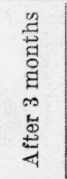 & 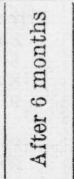 & 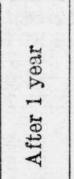 & 惡 & 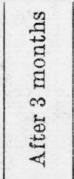 & 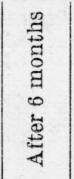 & 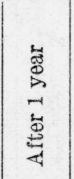 & 㱏 & 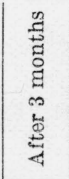 & 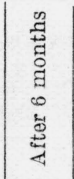 & 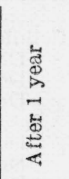 \\
\hline 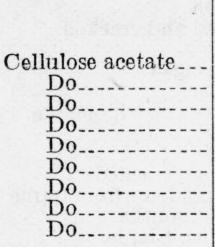 & $\begin{array}{l}A 1 \\
A 2 \\
A 3 \\
B 1 \\
B 2 \\
B 3 \\
C 1 \\
C 2 \\
D 1\end{array}$ & $\begin{array}{l}\text { Per- } \\
\text { cent } \\
91.2 \\
89.1 \\
87.5 \\
91.3 \\
90.8 \\
91.6 \\
89.3 \\
85.4 \\
84.4\end{array}$ & $\begin{array}{l}\text { Per- } \\
\text { cent } \\
91.6 \\
89.6 \\
87.9 \\
91.7 \\
90.8 \\
91.8 \\
89.0 \\
85.8 \\
87.7\end{array}$ & $\begin{array}{l}\text { Per- } \\
\text { cent } \\
84.5 \\
83.6 \\
87.1 \\
91.5 \\
90.8 \\
91.7 \\
89.6 \\
86.2 \\
86.2\end{array}$ & $\begin{array}{l}\text { Per- } \\
\text { cent } \\
75.1 \\
68.9 \\
71.7 \\
91.7 \\
91.1 \\
88.8 \\
90.2 \\
87.7 \\
52.6\end{array}$ & $\begin{array}{l}\text { Per- } \\
\text { cent } \\
87.1 \\
83.8 \\
80.0 \\
89.5 \\
88.4 \\
89.8 \\
85.4 \\
78.0 \\
75.1\end{array}$ & $\begin{array}{l}\text { Per- } \\
\text { cent } \\
89.1 \\
85.7 \\
83.6 \\
90.0 \\
89.0 \\
89.1 \\
85.2 \\
78.9 \\
85.0\end{array}$ & $\begin{array}{l}\text { Per- } \\
\text { cent } \\
80.6 \\
78.4 \\
82.0 \\
90.2 \\
89.4 \\
89.0 \\
87.2 \\
81.3 \\
84.1\end{array}$ & $\begin{array}{l}\text { Per- } \\
\text { cent } \\
72.3 \\
65.1 \\
66.8 \\
90.3 \\
89.6 \\
87.2 \\
87.5 \\
82.6 \\
49.4\end{array}$ & $\begin{array}{l}\text { Per- } \\
\text { cent } \\
88.3 \\
85.4 \\
83.0 \\
89.2 \\
87.9 \\
89.4 \\
86.4 \\
80.2 \\
80.9\end{array}$ & $\begin{array}{l}\text { Per- } \\
\text { cent } \\
88.0 \\
84.8 \\
83.1 \\
90.3 \\
89.3 \\
88.2 \\
86.4 \\
81.5 \\
86.1\end{array}$ & $\begin{array}{l}\text { Per- } \\
\text { cent } \\
78.6 \\
75.3 \\
79.0 \\
89.4 \\
88.5 \\
86.7 \\
86.9 \\
81.3 \\
83.7\end{array}$ & $\begin{array}{c}\text { Per- } \\
\text { cent } \\
71.1 \\
64.1 \\
65.7 \\
90.1 \\
89.3 \\
86.0 \\
88.0 \\
83.6 \\
50.2\end{array}$ \\
\hline $\begin{array}{c}\text { Cellulose acetobu- } \\
\text { tyrate. }\end{array}$ & $S 1$ & 92.2 & 92.2 & 92.4 & 92.4 & 91.2 & 91.0 & 91.6 & 91.1 & 90.9 & 91.2 & 91.3 & 90.9 \\
\hline $\begin{array}{l}\text { Cellulose nitrate } . . \\
\text { Do. }\end{array}$ & $\begin{array}{l}E 1 \\
F 1\end{array}$ & $\begin{array}{l}91.6 \\
83.3\end{array}$ & $\begin{array}{l}87.0 \\
79.9\end{array}$ & $\begin{array}{l}40.3 \\
35.0\end{array}$ & 29.8 & $\begin{array}{l}90.0 \\
84.7\end{array}$ & $\begin{array}{l}80.3 \\
76.8\end{array}$ & $\begin{array}{l}31.8 \\
29.4\end{array}$ & $\begin{array}{l}23.3 \\
20.9\end{array}$ & $\begin{array}{l}89.1 \\
85.0\end{array}$ & $\begin{array}{l}76.7 \\
73.3\end{array}$ & $\begin{array}{l}31.5 \\
27.2\end{array}$ & $\begin{array}{l}24.0 \\
20.7\end{array}$ \\
\hline $\begin{array}{r}\text { Ethylcellulose } \\
\text { Do } \\
\text { Do.............. }\end{array}$ & $\begin{array}{l}G 1 \\
H 1 \\
I 1\end{array}$ & $\begin{array}{l}82.7 \\
86.5 \\
91.2\end{array}$ & $\begin{array}{l}44.2 \\
86.2 \\
90.0\end{array}$ & 57.9 & & $\begin{array}{l}74.7 \\
83.3 \\
89.2\end{array}$ & $\begin{array}{l}41.7 \\
83.9 \\
87.7\end{array}$ & 53.3 & & $\begin{array}{l}72.6 \\
81.8 \\
88.5\end{array}$ & $\begin{array}{l}42.4 \\
83.2 \\
87.7\end{array}$ & 51.6 & (n) \\
\hline 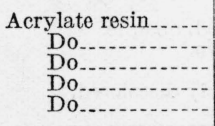 & $\begin{array}{l}J 1 \\
J 2 \\
K 1 \\
K 2 \\
K 3\end{array}$ & $\begin{array}{l}92.9 \\
93.2 \\
93.1 \\
94.1 \\
93.7\end{array}$ & $\begin{array}{l}92.5 \\
92.8 \\
93.0 \\
93.4 \\
93.3\end{array}$ & $\begin{array}{r}92.7 \\
93.1 \\
92.6 \\
93.5 \\
\text { d } 92.5\end{array}$ & \begin{tabular}{c|}
92.9 \\
93.6 \\
93.1 \\
93.5 \\
.---
\end{tabular} & $\begin{array}{l}92.2 \\
92.5 \\
92.7 \\
93.0 \\
93.1\end{array}$ & $\begin{array}{l}91.7 \\
92.0 \\
91.1 \\
92.7 \\
93.0\end{array}$ & $\begin{array}{r}92.5 \\
92.4 \\
90.3 \\
92.9 \\
\text { d } 91.5\end{array}$ & $\begin{array}{r}92.3 \\
92.7 \\
90.5 \\
93.0 \\
-\cdots\end{array}$ & $\begin{array}{l}92.1 \\
92.4 \\
92.6 \\
93.2 \\
93.2\end{array}$ & $\begin{array}{l}91.6 \\
92.0 \\
90.1 \\
92.8 \\
92.2\end{array}$ & $\begin{array}{r}91.6 \\
91.8 \\
87.9 \\
92.8 \\
\text { d91.5 }\end{array}$ & $\begin{array}{r}91.8 \\
92.6 \\
88.7 \\
93.1 \\
- \\
-\end{array}$ \\
\hline $\begin{array}{l}\text { Vinyl chloride. } \\
\text { acetate resin } \\
\text { Do. }\end{array}$ & $\begin{array}{l}L 1 \\
L 2\end{array}$ & $\begin{array}{l}86.5 \\
85.1\end{array}$ & $\begin{array}{l}82.7 \\
77.4\end{array}$ & $\begin{array}{l}52.2 \\
12.0\end{array}$ & $\begin{array}{l}54.3 \\
13.3\end{array}$ & $\begin{array}{l}83.3 \\
76.9\end{array}$ & $\begin{array}{l}72.7 \\
62.8\end{array}$ & $\begin{array}{r}19.8 \\
6.2\end{array}$ & $\begin{array}{r}22.4 \\
4.4\end{array}$ & $\begin{array}{l}84.9 \\
76.6\end{array}$ & $\begin{array}{l}74.7 \\
65.4\end{array}$ & $\begin{array}{l}33.2 \\
15.2\end{array}$ & $\begin{array}{l}37.4 \\
15.1\end{array}$ \\
\hline $\begin{array}{c}\text { Vinyl acetal resin } \\
\text { Do }\end{array}$ & $\begin{array}{l}M 1 \\
N 1\end{array}$ & $\begin{array}{l}89.0 \\
85.6\end{array}$ & $\begin{array}{l}87.3 \\
71.8\end{array}$ & $\begin{array}{r}79.2 \\
\mathrm{~d} 42.4\end{array}$ & 48.0 & $\begin{array}{l}85.6 \\
81.2\end{array}$ & $\begin{array}{l}84.7 \\
65.3\end{array}$ & $\begin{array}{r}74.9 \\
\text { d35. } 0\end{array}$ & 40.3 & $\begin{array}{l}85.8 \\
79.6\end{array}$ & $\begin{array}{l}84.2 \\
64.1\end{array}$ & $\begin{array}{r}73.1 \\
\mathrm{~d} 36.5\end{array}$ & 41.2 \\
\hline $\begin{array}{l}\text { Glyceryl-phthalate } \\
\text { resin }\end{array}$ & 01 & 87.7 & & d87. 0 & & 80.2 & & d 78.5 & & 79. 3 & & d 77.7 & \\
\hline
\end{tabular}

a Pyrometer red filter (Corning Glass Works).

b No. 61 Wratten filter (Eastman Kodak Co.).

- No. 47 Wratten filter (Eastman Kodak Co.).

d After 9 months. 


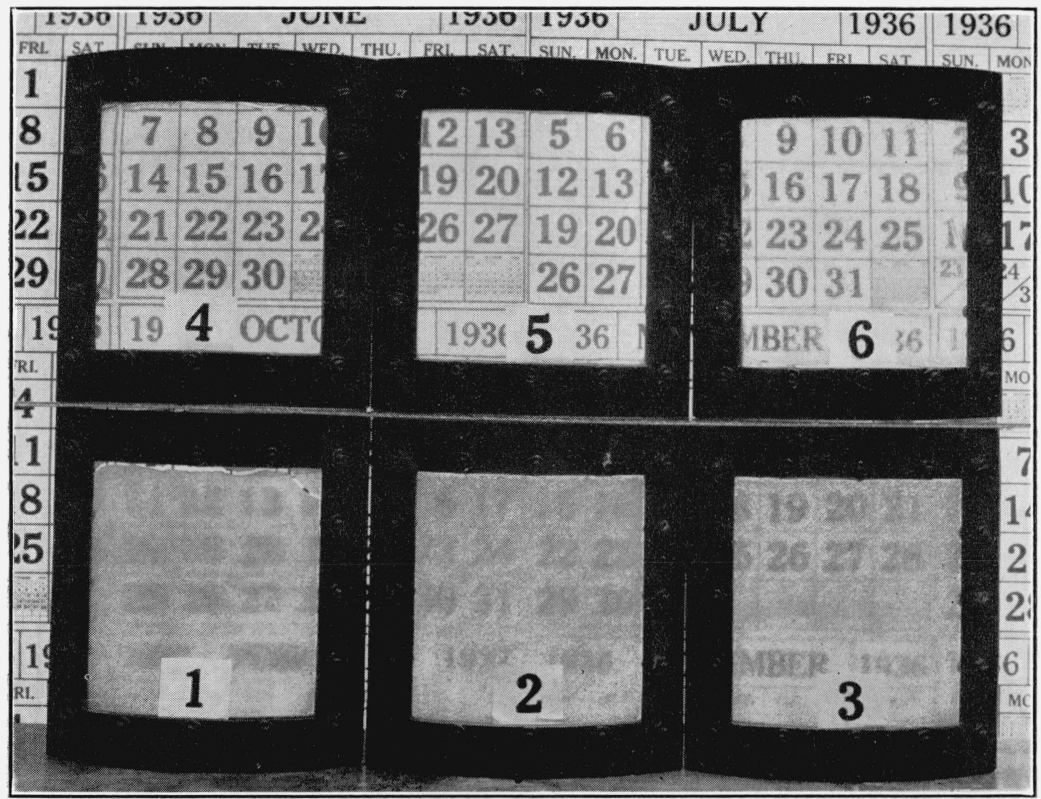

FiguRE 3.-Exposure panels after 1 year out-of-doors.

\begin{tabular}{|c|c|c|}
\hline $\begin{array}{c}\text { Identification } \\
\text { number }\end{array}$ & Material & Sample \\
\hline $\begin{array}{l}1 \\
2 \\
3 \\
4 \\
5 \\
6\end{array}$ & 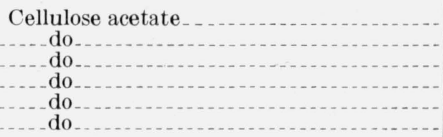 & $\begin{array}{l}A 1 \\
A 2 \\
A 3 \\
B 1 \\
B 2 \\
B 3\end{array}$ \\
\hline
\end{tabular}




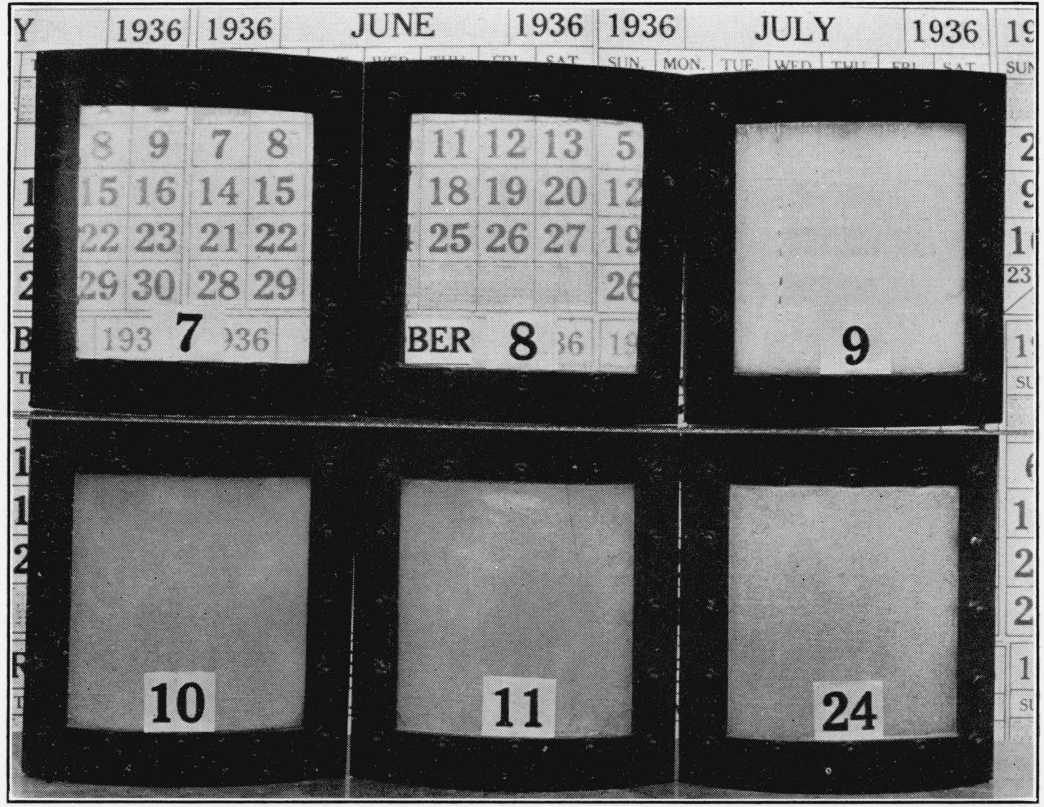

FigURE 4.-Exposure panels after 1 year out-of-doors.

(Sample 24 exposed for 9 months only.)

\begin{tabular}{|c|c|c|}
\hline $\begin{array}{c}\text { Identification } \\
\text { number }\end{array}$ & Material & Sample \\
\hline $\begin{array}{l}7+\ldots \\
8 \\
9 \\
90 \\
11 \\
24\end{array}$ & $\begin{array}{c}\text { Cellulose acetate } \\
0 \text { do do } \\
\text { Cellulose nitrate }\end{array}$ & $\begin{array}{l}C 1 \\
C 3 \\
D 1 \\
E 1 \\
F 1 \\
N 1\end{array}$ \\
\hline
\end{tabular}




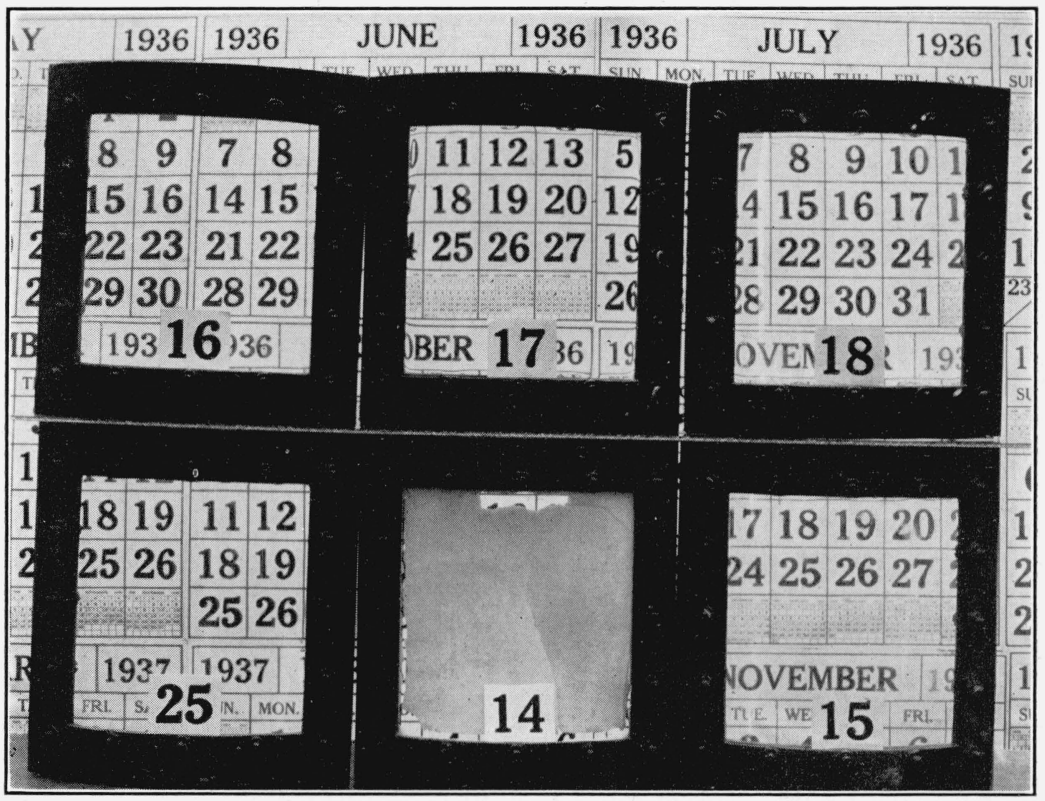

Figure 5.-Exposure panels after 1 year out-of-doors.

(Sample 25 exposed for 9 months only.)

\begin{tabular}{|c|c|c|}
\hline $\begin{array}{c}\text { Identification } \\
\text { number }\end{array}$ & Material & Sample \\
\hline $\begin{array}{l}16 \\
17 \\
18 \\
25 \\
14 \\
15 \\
15\end{array}$ & $\begin{array}{l}\text { Acrylate resin } \\
\text { do } \\
\text { Ethylcellulose } \\
\text { Acrylate resin }\end{array}$ & $\begin{array}{l}J 2 \\
K 1 \\
K 2 \\
K 3 \\
I 1 \\
J 1\end{array}$ \\
\hline
\end{tabular}




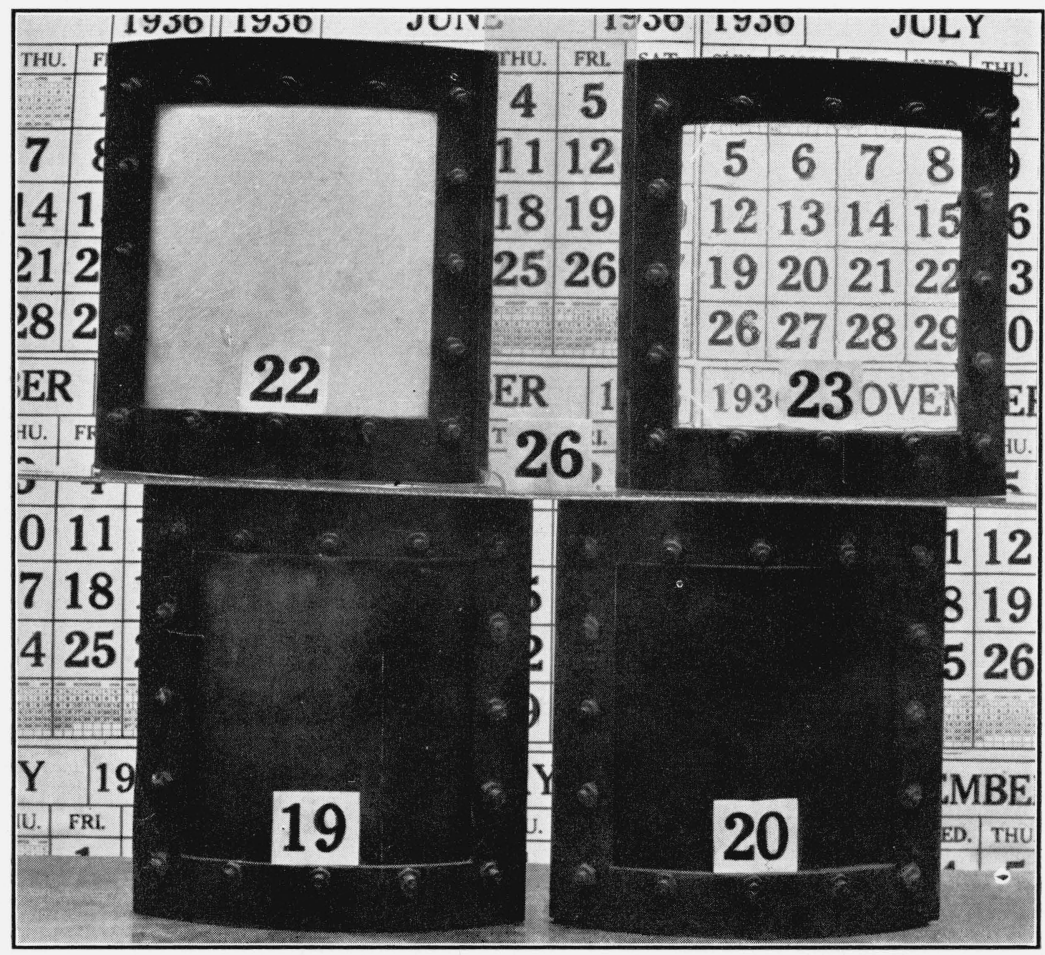

Figure 6.-Exposure panels after 1 year out-of-doors.

(Sample 26 exposed for 9 months only.)

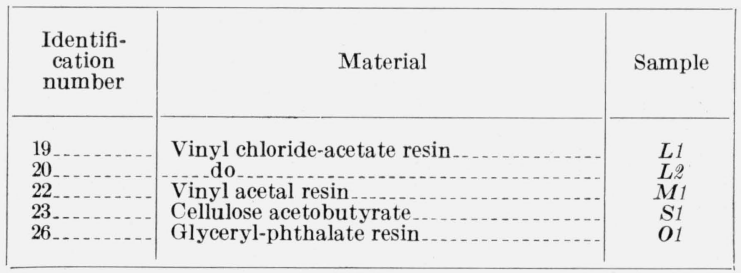


TABLE 7.-Effect of outside exposure on haziness of transparent plastics

\begin{tabular}{|c|c|c|c|c|c|c|}
\hline \multirow{2}{*}{ Material } & \multirow{2}{*}{$\begin{array}{c}\text { Sam- } \\
\text { ple }\end{array}$} & \multicolumn{5}{|c|}{ Haze value } \\
\hline & & Initial & $\stackrel{3}{\text { months }}$ & $\begin{array}{c}6 \\
\text { months }\end{array}$ & $\stackrel{9}{9}$ & $\begin{array}{c}12 \\
\text { months }\end{array}$ \\
\hline 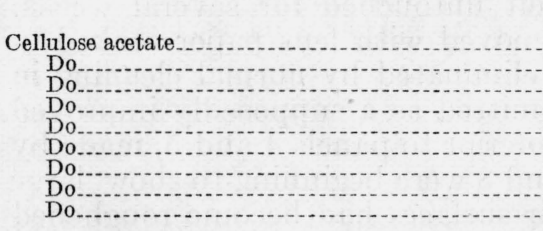 & $\begin{array}{l}A 1 \\
A 2 \\
A 3 \\
B 1 \\
B 2 \\
B 3 \\
C 1 \\
C 2 \\
D 1\end{array}$ & $\begin{array}{r}\text { Percent } \\
4.1 \\
6.0 \\
7.7 \\
6.7 \\
4.7 \\
3.6 \\
6.4 \\
9.4 \\
7.2\end{array}$ & $\begin{array}{r}\text { Percent } \\
4.7 \\
6.9 \\
7.5 \\
7.5 \\
5.0 \\
3.8 \\
7.5 \\
9.7 \\
11.8\end{array}$ & $\begin{array}{r}\text { Percent } \\
14.4 \\
14.5 \\
11.5 \\
8.3 \\
7.2 \\
5.1 \\
11.5 \\
12.2 \\
16.5\end{array}$ & $\begin{array}{r}\text { Percent } \\
24.1 \\
21.4 \\
20.6 \\
8.3 \\
7.9 \\
6.4 \\
10.4 \\
11.9 \\
33.0\end{array}$ & $\begin{array}{r}\text { Percent } \\
38.5 \\
30.8 \\
24.3 \\
9.3 \\
7.9 \\
10.0 \\
11.3 \\
12.5 \\
56.4\end{array}$ \\
\hline Cellulose acetobutyrate & S1 & 5.4 & 4.7 & 4.6 & 4. 6 & 6.0 \\
\hline Cellulose nitrate & $\begin{array}{l}E 1 \\
F 1\end{array}$ & $\begin{array}{l}3.2 \\
4.2\end{array}$ & $\begin{array}{l}7.8 \\
7.5\end{array}$ & $\begin{array}{l}83.8 \\
84.8\end{array}$ & $\begin{array}{l}96 \\
97\end{array}$ & $\begin{array}{l}97 \\
98\end{array}$ \\
\hline $\begin{array}{l}\text { Ethylcellulose } \\
\text { Do } \\
\text { Do }\end{array}$ & $\begin{array}{l}\text { G1 } \\
H 1 \\
I 1\end{array}$ & $\begin{array}{r}26.0 \\
9.0 \\
5.8\end{array}$ & $\begin{array}{r}78.8 \\
17.0 \\
7.2\end{array}$ & 86.3 & $99^{-\cdots}$ & 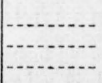 \\
\hline $\begin{array}{l}\text { Acrylate resin } \\
\text { Do } \\
\text { Do-- } \\
\text { Do } \\
\text { Do }\end{array}$ & $\begin{array}{l}J 1 \\
J 2 \\
K 1 \\
K 2 \\
K 3\end{array}$ & $\begin{array}{l}4.4 \\
3.5 \\
2.7 \\
2.6 \\
1.3\end{array}$ & $\begin{array}{l}4.7 \\
4.5 \\
2.8 \\
3.2 \\
1.7\end{array}$ & $\begin{array}{l}5.3 \\
4.8 \\
2.5 \\
3.4 \\
2.8\end{array}$ & $\begin{array}{l}5.3 \\
4.7 \\
3.2 \\
3.1 \\
4.0\end{array}$ & $\begin{array}{l}5.2 \\
4.4 \\
3.7 \\
3.8\end{array}$ \\
\hline $\begin{array}{l}\text { Vinyl chloride-acetate resin } \\
\text { Do... }\end{array}$ & $\begin{array}{l}L 1 \\
L 2\end{array}$ & $\begin{array}{r}6.3 \\
10.6\end{array}$ & $\begin{array}{r}7.2 \\
15.0\end{array}$ & $\begin{array}{l}11.1 \\
38\end{array}$ & $\begin{array}{l}18.2 \\
55\end{array}$ & $\begin{array}{l}25.9 \\
64\end{array}$ \\
\hline $\begin{array}{l}\text { Vinyl acetal resin } \\
\text { Do }\end{array}$ & $\begin{array}{l}M 1 \\
\text { N1 }\end{array}$ & $\begin{array}{l}3.2 \\
8.4\end{array}$ & $\begin{array}{l}10.3 \\
27.8\end{array}$ & $\begin{array}{l}74 \\
90\end{array}$ & $\begin{array}{l}95 \\
94\end{array}$ & 96 \\
\hline Glyceryl-phthalate resir & 01 & 7.7 & & 9.4 & 10.0 & \\
\hline
\end{tabular}

The condition of the samples after 12 months of exposure on the roof is shown in figures 3 to 6 . Examination of the photographs indicates clearly that the samples of acrylate resins, nos. $15,16,17$, and 18 , are in the best condition after the year's exposure. This same conclusion is reached from a consideration of the values for light transmission in tables 5 and 6 and for haze in table 7 . The surfaces of three of these samples, however, had begun to craze and crack. These cracks are not readily visible when viewed by directly transmitted light, but become very pronounced when illuminated so that the light scattered by them can be observed. Figure 7 shows panels 16,17 , and 18 taken at a suitable angle to show this crazing. It should be kept in mind that these frames are curved and that cracks like those which show at the center portion of panels 16 and 18 are present throughout the whole sheet. Sample $17(K I)$ did not show any evidences of crazing; however, it contained a plasticizer which caused a slight yellowing of the sheet upon exposure. This discoloration is indicated by the results of the light-transmission measurements using a blue filter, shown in table 6 . Some samples of acrylate resin kept in storage for approximately 18 months developed similar crazing, as shown in figure 8 . One of the manufacturers of this type of plastic has stated that his product has been modified so as to avoid this failure. Tests on these new materials are in progress.

The cellulose acetate transparent sheets tested are shown in figures 3 and 4 , panels 1 to 9 , after 12 months' exposure. The products of different manufacturers and of different samples from the same 
manufacturer varied considerably in their behavior upon weathering. Panels 1 to 3 had crazed badly, discolored, and become practically opaque. Panels 4 and 5 were in the best condition of any of the cellulose acetate samples after 1 year on the roof. Even these had become considerably hazy and one had cracked at the top of the frame because of shrinkage. These two samples tended to become coated with a frosty layer when left untouched for several weeks. This surface coating was readily removed with lens paper soaked in kerosene, and would be constantly eliminated by normal cleaning in service. Panel 6 was a sample submitted as a supposedly improved product, but it is quite apparently inferior to panels 4 and 5 , made by the same manufacturer. Panels 7 and 8 were beginning to show large surface cracks after 1 year and their surfaces had become roughened or "pebbled", thereby causing distortion of vision through them. Panel 9 had become practically opaque in 1 year; the cracking which caused this had taken place fairly regularly over the period of exposure as indicated by the haze values in table 7 .

It is well known that deterioration of cellulose nitrate is accelerated by ultraviolet light. Samples 10 and 11 show how completely opaque this plastic becomes during 1 year of exposure to sunlight. Table 7 indicates that the major portion of the breakdown occurred between the 3- and 6-months period, namely, during June, July, and August. The condition of these samples after 3 months of exposure is shown in figure 9. The crazing which occurs is confined to the outer surface of the material, the back remaining smooth and transparent.

The ethylcellulose sheets tested were among the first samples of this plastic which became available in this country. As indicated in table 7, figure 9 (panel 12 after 3 months) and figure 5 (panel 14 after 12 months) these materials were not resistant to exposure on the roof. A marked increase in the haziness of two of the samples took place within 3 months, and the third sample deteriorated rapidly during the following 3 months. It is understood that manufacturers of these materials have improved the stability of ethylcellulose sheets during the interval which has elapsed since these materials were received. New materials are being tested to determine whether a grade which would be suitable for airplane use has been developed.

The vinyl resin sheets, all of which were experimental samples, did not have satisfactory resistance to weathering. The polyvinyl chloride-acetate sheets (panels 19 and 20 in fig. 6) discolored rapidly, becoming dark purple. This purple discoloration was entirely a surface-layer effect and extended only one-fifth of the way through the sample, the remainder being apparently unaffected. The vinyl acetal samples (panel 22 in fig. 6 after 12 months, and panel 24 in fig. 4 after 9 months) did not discolor but became opaque and showed evidences of surface cracking.

The sheet of cellulose acetobutyrate (panel 23 in fig. 6) was cast from a solution in organic solvents. The bubbles which are seen were present in the sheet as it was received. As indicated in tables 5,6 , and 7 , no marked changes in the light-transmission and haze characteristics of this material took place during the exposure period. The streak which is present on one side of the picture of panel 23 is an optical effect only, no cracks having appeared in the exposed sample.

The glyceryl-phthalate resin was too brittle to be bent to the 5inch radius of curvature of the test frames. A flat piece was exposed 


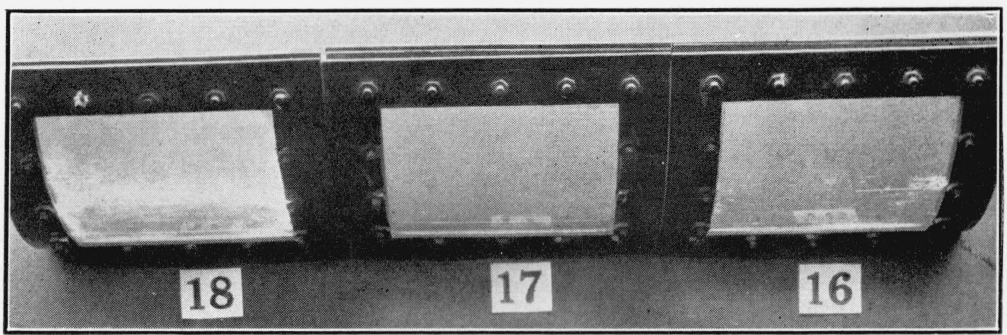

FIGURE 7.-Acrylate resin samples after 1 year of exposure, showing crazing.

\begin{tabular}{|c|c|c|}
\hline $\begin{array}{l}\text { Identifi- } \\
\text { cation } \\
\text { number }\end{array}$ & Material & Sample \\
\hline $\begin{array}{l}16 \ldots \ldots \\
17 \\
18\end{array}$ & Acrylate resin & $\begin{array}{l}J 2 \\
K 1 \\
K 2\end{array}$ \\
\hline
\end{tabular}

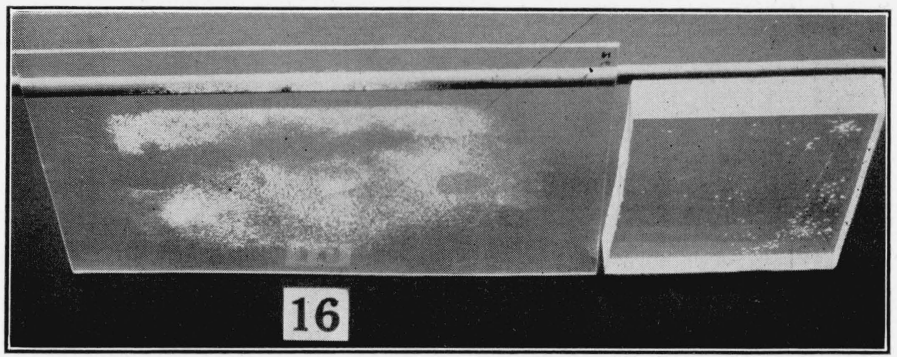

FIGURE 8.-Acrylate resin samples after approximately 1 year in storage, showing crazing.

\begin{tabular}{|c|c|c|}
\hline $\begin{array}{c}\text { Identifi- } \\
\text { cation } \\
\text { number }\end{array}$ & Material & Sample \\
\hline $16 \ldots \ldots . . . .$. & Acrylate resin _............... & J2 \\
\hline
\end{tabular}




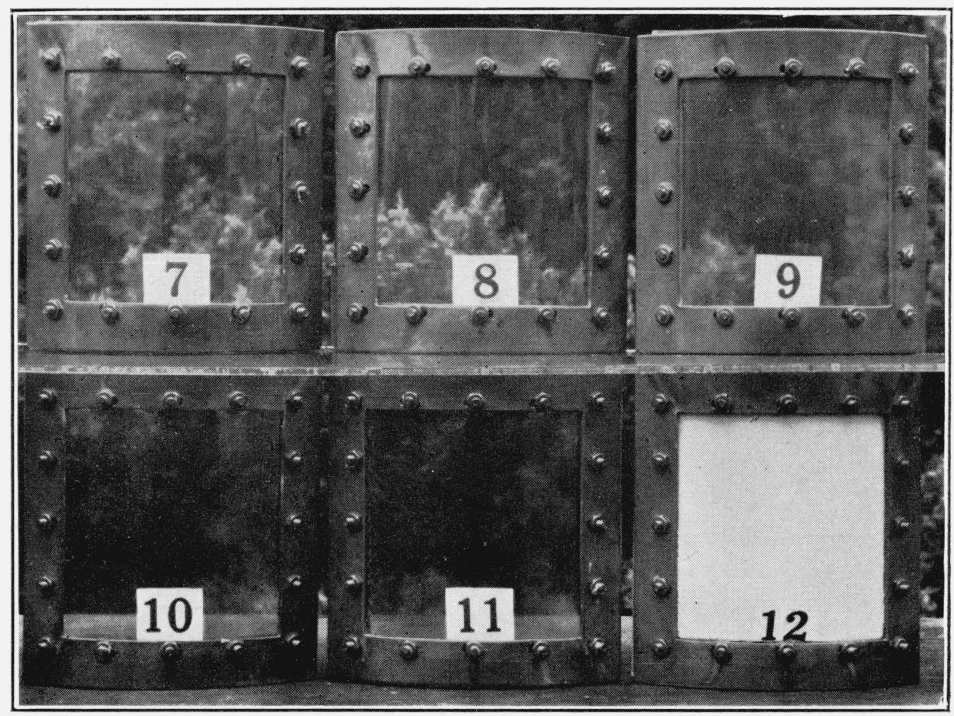

Figure 9.-Exposure panels after 3 months out-of-doors

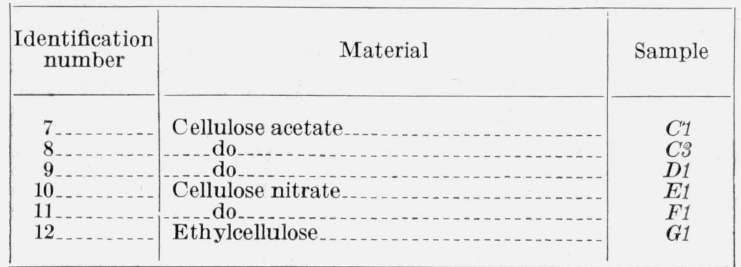




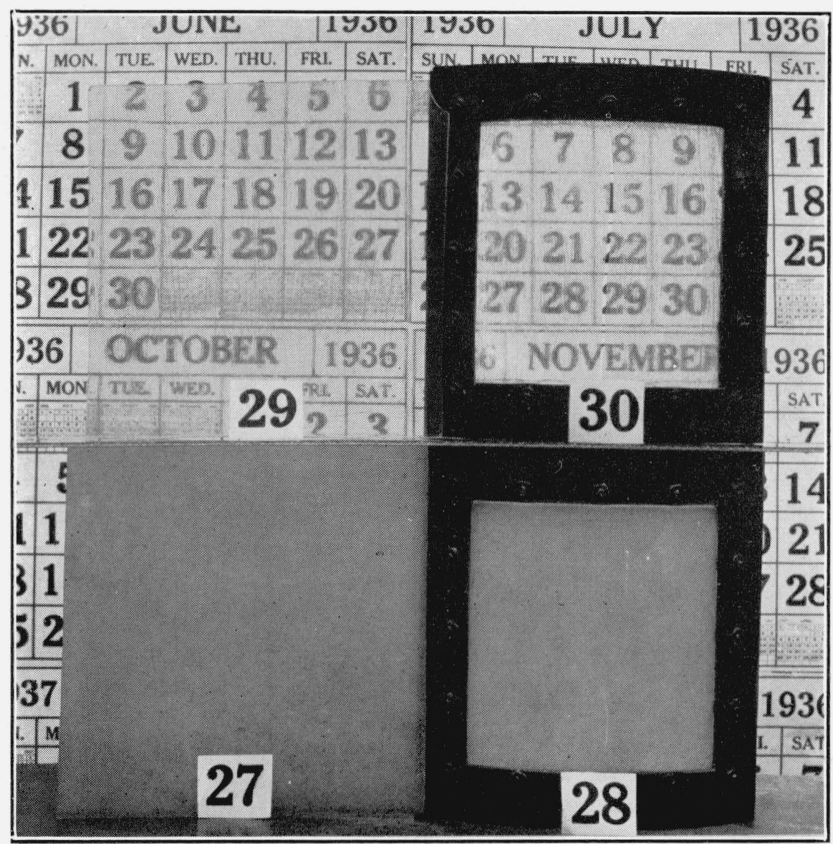

FIgURE 10.-Exposure samples of cellulose acetate and cellulose nitrate after 9 months out-of-doors.

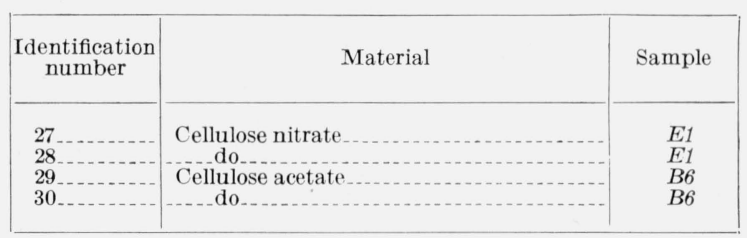


for 9 months on the roof and is shown in figure 6 (no. 26). No cracking or crazing is evident but the material had discolored considerably.

The possible effects on crazing of the bolting of the materials in a stressed state in the test frames was studied by exposing flat sheets of cellulose acetate and cellulose nitrate simultaneously with the same materials fastened in the curved panels. Figure 10, which shows the condition of the specimens after 9 months of exposure on the roof, indicates that the crazing took place equally rapidly under the two conditions. The erack down the middle of panel 30 was the result of strain caused by shrinkage due to loss of volatile material.

The effect of 1 year of exposure out-of-doors on the white light transmission and haziness of laminated and ordinary glass is shown in table 8. No marked breakdown of these products took place during this period. The laminated glass made with an acrylate plastic gave somewhat erratic results in the measurement of haze because the plastic tended to squeeze out at the edges, thereby leaving the product slightly wedge-shaped. However, there was no apparent change at the end of 1 year on the roof in the clarity or appearance of this type of laminated glass.

TABLE 8.-Effect of outdoor exposure on white light transmission and haziness of glass windshield products

\begin{tabular}{|c|c|c|c|c|c|c|c|}
\hline \multirow{2}{*}{ Type of glass } & \multirow{2}{*}{$\begin{array}{l}\text { Type of } \\
\text { plastic } \\
\text { lamination }\end{array}$} & \multirow{2}{*}{$\begin{array}{c}\text { Sam- } \\
\text { ple }\end{array}$} & \multirow{2}{*}{$\begin{array}{l}\text { Thick- } \\
\text { ness }\end{array}$} & \multicolumn{2}{|c|}{$\begin{array}{l}\text { Light transmis- } \\
\text { sion }\end{array}$} & \multicolumn{2}{|c|}{ Haze value } \\
\hline & & & & Initial & $\begin{array}{l}\text { After } 12 \\
\text { months }\end{array}$ & Initial & $\begin{array}{l}\text { After } 12 \\
\text { months }\end{array}$ \\
\hline $\begin{array}{l}\text { Thin plate } \\
\text { Thin plate safety } \\
10-0 z \text { sheet safety } \\
12-\text { to } 14-0 z \text { sheet. } \\
12-\text { to } 14-o z \text { sheet safety. } \\
1 / 4 \text {-in. plate }\end{array}$ & 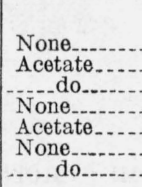 & $\begin{array}{l}X 1 \\
X 5 \\
X 6 \\
X 3 \\
X \gamma \\
X 4 \\
X 8\end{array}$ & $\begin{array}{r}\text { Mils } \\
85 \\
186 \\
130 \\
67 \\
152 \\
225 \\
248\end{array}$ & $\begin{array}{r}\text { Percent } \\
86.7 \\
81.6 \\
91.2 \\
93.1 \\
91.2 \\
91.2 \\
92.5\end{array}$ & $\begin{array}{r}\text { Percent } \\
86.8 \\
82.5 \\
92.0 \\
93.1 \\
91.9 \\
91.1 \\
91.7\end{array}$ & \begin{tabular}{r|} 
Percent \\
1.3 \\
1.5 \\
1.1 \\
1.0 \\
1.4 \\
0.9 \\
1.4
\end{tabular} & $\begin{array}{r}\text { Percent } \\
1.2 \\
1.7 \\
1.3 \\
1.2 \\
1.3 \\
0.8 \\
1.1\end{array}$ \\
\hline $\begin{array}{l}\text { Thin sheet safety } \\
\text { Do } \\
\text { Plate safety } \\
\text { Plate and thin sheet safety } \\
\text { Plate and sheet safety }\end{array}$ & 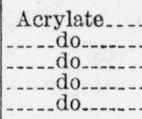 & $\begin{array}{l}Y 1 \\
Y 2 \\
Y 3 \\
Y 4 \\
Y 5\end{array}$ & $\begin{array}{l}107 \\
130 \\
248 \\
228 \\
238\end{array}$ & $\begin{array}{l}92.8 \\
92.6 \\
89.5 \\
91.3 \\
89.9\end{array}$ & $\begin{array}{l}92.0 \\
92.2 \\
89.2 \\
90.7 \\
89.3\end{array}$ & $\begin{array}{l}0.9 \\
1.4 \\
1.1 \\
1.2 \\
0.9\end{array}$ & $\begin{array}{l}1.3 \\
1.1 \\
0.6 \\
1.0 \\
1.0\end{array}$ \\
\hline $\begin{array}{l}\text { Plate safety } \\
\text { Do } \\
\text { Sheet safety. }\end{array}$ & $\begin{array}{l}\text { Nitrate } \\
\text { Vinyl-..... } \\
-\end{array}$ & $\begin{array}{l}Z 1 \\
Z 2 \\
Z 3\end{array}$ & $\begin{array}{l}234 \\
261 \\
144\end{array}$ & $\begin{array}{l}73.3 \\
71.4 \\
91.8\end{array}$ & $\begin{array}{l}\text { a } 73.0 \\
\text { s } 71.2 \\
\text { a } 91.5\end{array}$ & $\begin{array}{l}1.5 \\
1.5 \\
1.6\end{array}$ & $\begin{array}{l}\approx 1.4 \\
\approx 1.7 \\
\approx 1.4\end{array}$ \\
\hline
\end{tabular}

- After 9 months of exposure.

\section{ACCELERATED AGING}

Accelerated aging tests were made in an apparatus having a carbonarc light. Specimens 6 by $1 \frac{1}{2}$ inches were used, a portion of each being covered with aluminum to obtain a ready comparison of exposed and unexposed material. The samples were rotated around the carbon are at a distance of 2 feet, at the rate of one revolution every 20 minutes. Tap water was sprayed on the plastics at one location in the apparatus; the duration of its application to each sample was about 15 seconds. The samples were tested after 500 and 1,000 hours. The results of these tests are shown in table 9. Figure 11 
shows the condition of the specimens after 1,000 hours of exposure. The unexposed portion is at the top of each specimen in the photograph.

TABLE 9.-Accelerated aging of transparent plastics by carbon-arc light with intermittent water spray

\begin{tabular}{|c|c|c|c|c|c|}
\hline \multirow{2}{*}{ Material } & \multirow{2}{*}{$\begin{array}{l}\text { Sam- } \\
\text { ple }\end{array}$} & \multicolumn{3}{|c|}{ White-light transmission } & \multirow{2}{*}{$\begin{array}{l}\text { Remarks on condition after } \\
1,000 \text { hours }\end{array}$} \\
\hline & & Initial & $500 \mathrm{hr}$ & $1,000 \mathrm{hr}$ & \\
\hline Cellulose acetate. - & $A 1$ & $\begin{array}{r}\text { Percent } \\
88.2\end{array}$ & $\begin{array}{r}\text { Percent } \\
90.2\end{array}$ & $\begin{array}{r}\text { Percent } \\
89.2\end{array}$ & Warped, cracked, and slightly \\
\hline $\begin{array}{l}\text { Do. } \\
\text { Do } \\
\text { Do } \\
\text { Do } \\
\text { Do }\end{array}$ & $\begin{array}{l}B 1 \\
B 3 \\
C 1 \\
C S \\
D 1\end{array}$ & $\begin{array}{l}91.3 \\
91.4 \\
87.9 \\
81.7 \\
76.8\end{array}$ & $\begin{array}{l}92.3 \\
92.6 \\
89.0 \\
84.6 \\
82.5\end{array}$ & $\begin{array}{l}91.7 \\
91.8 \\
89.6 \\
84.8 \\
86.0\end{array}$ & $\begin{array}{l}\text { Surface roughened. } \\
\text { Warped and slightly clouded. } \\
\text { Warped. } \\
\text { Slightly warped. } \\
\text { Cracked and bleached. }\end{array}$ \\
\hline Cellulose acetobutyrate.... & S1 & 92.2 & 92.2 & 92.2 & Slightly warped. \\
\hline Cellulose nitrate... & E1 & 91.2 & 91.5 & 87.6 & Warped, discolored, and slight \\
\hline Do........... & $F 1$ & 84.7 & 86.0 & 86.7 & Discolored. \\
\hline $\begin{array}{l}\text { Ethylcellulose } \\
\text { Do } \\
\text { Do }\end{array}$ & $\begin{array}{l}\text { G1 } \\
H 1 \\
I 1\end{array}$ & $\begin{array}{l}82.3 \\
85.0 \\
91.3\end{array}$ & $\begin{array}{l}81.3 \\
85.0 \\
89.6\end{array}$ & $\begin{array}{l}85.0 \\
78.3\end{array}$ & $\begin{array}{l}\text { Opaque at } 800 \mathrm{hr} \text {; friable. } \\
\text { Warped and cloudy. } \\
\text { Warped; surface frosty. }\end{array}$ \\
\hline $\begin{array}{l}\text { Acrylate resin } \\
\text { Do } \\
\text { Do } \\
\text { Do }\end{array}$ & $\begin{array}{l}J 1 \\
J 2 \\
K 1 \\
K 2\end{array}$ & $\begin{array}{l}93.3 \\
93.4 \\
93.6 \\
94.0\end{array}$ & $\begin{array}{l}93.4 \\
93.3 \\
93.1 \\
93.9\end{array}$ & $\begin{array}{l}93.3 \\
92.7 \\
92.5 \\
93.3\end{array}$ & $\begin{array}{l}\text { Surface pitted. } \\
\text { No marked change. } \\
\text { Do. } \\
\text { Do. }\end{array}$ \\
\hline $\begin{array}{l}\text { Vinyl chloride-acetate resin } \\
\text { Do }\end{array}$ & $\begin{array}{l}L 1 \\
L 2\end{array}$ & $\begin{array}{l}82.4 \\
79.2\end{array}$ & $\begin{array}{l}82.7 \\
59.2\end{array}$ & $\begin{array}{r}17.1 \\
0.7\end{array}$ & $\begin{array}{l}\text { Discolored purple. } \\
\text { Discolored purple; opaque. }\end{array}$ \\
\hline Vinyl acetal resin ............. & M1 & 89.0 & a 88.3 & (b) & Warped and cloudy. \\
\hline Styrene... & $R 1$ & 74. 7 & 72.8 & 59.8 & Darkened and cracked. \\
\hline
\end{tabular}

a $163 \mathrm{hr}$.

b Too warped to measure.

The cellulose acetate materials in general were improved in regard to light transmission, because of bleaching of the blue dye added to the original plastic. The specimens were held only by light spring clamps and many of the cellulose acetate specimens warped during the test. The cellulose nitrate samples were less affected by 1,000 hours in the accelerated aging apparatus than by 3 months (March, April, and May) of exposure out-of-doors. One sample of ethylcellulose was in a very friable state after 1,000 hours of exposure to the carbon-are light. The acrylate resins were practically unchanged after this treatment. The effect of the carbon-arc light on the polyvinyl chloride-acetate samples was very pronounced, and they were converted from the transparent condition to purplish-colored opaque masses. This change was confined to a thin layer at the surface of the sample, which indicated practically complete absorption of the harmful light radiation. The styrene and vinyl acetal samples were rapidly deteriorated in this test. The cellulose acetobutyrate was practically unaffected. Salt deposited during the alternate wetting and drying cycles prevented accurate determination of haze changes.

A second group of specimens was subjected to the light from the carbon-arc lamp without a water spray so that haze measurements could be made. The samples were subjected to a somewbat higher temperature in thic test, approximately $55^{\circ} \mathrm{C}$ instead of $40^{\circ} \mathrm{C}$ when 


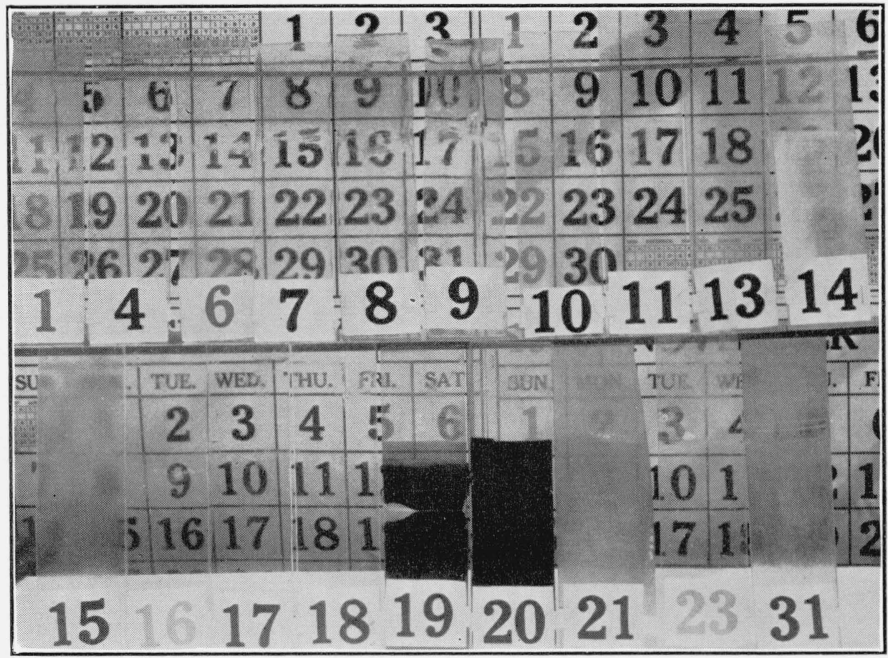

FIGURE 11.-Condition of samples after exposure to carbon-arc light for 1,000 hours with intermittent water spray

\begin{tabular}{|c|c|c|c|c|c|}
\hline $\begin{array}{c}\text { Identifica- } \\
\text { tion } \\
\text { number }\end{array}$ & Material & Sample & $\begin{array}{c}\text { Identifica- } \\
\text { tion } \\
\text { number }\end{array}$ & Material & Sample \\
\hline $\begin{array}{r}1 \\
4 \\
6 \\
7 \\
7 \\
8 \\
9 \\
10 \\
11 \\
13 \\
14 \\
\end{array}$ & $\begin{array}{l}\text { Cellulose acetate } \\
\text { do do do } \\
\text { Cellulose nitrate } \\
\text { Ethylcellulose }\end{array}$ & $\begin{array}{l}A 1 \\
B 1 \\
B 3 \\
C 1 \\
C 3 \\
D 1 \\
E 1 \\
F 1 \\
H 1 \\
I 1\end{array}$ & $\begin{array}{l}15 \\
16 \\
17 \\
18 \\
19 \\
20 \\
21 \\
23 \\
31\end{array}$ & $\begin{array}{l}\text { Acrylate resin } \\
\text { do do } \\
\text { do } \\
\text { Vinyl chloride-acetate } \\
\text { resin } \\
\text { do } \\
\text { Styrene } \\
\text { Cellulose acetobutyrate } \\
\text { Phenol-formaldehyde } \\
\text { resin. }\end{array}$ & $\begin{array}{l}J 1 \\
J 2 \\
K 1 \\
K 2 \\
\\
L 1 \\
L 2 \\
R 1 \\
S 1 \\
U 1\end{array}$ \\
\hline
\end{tabular}




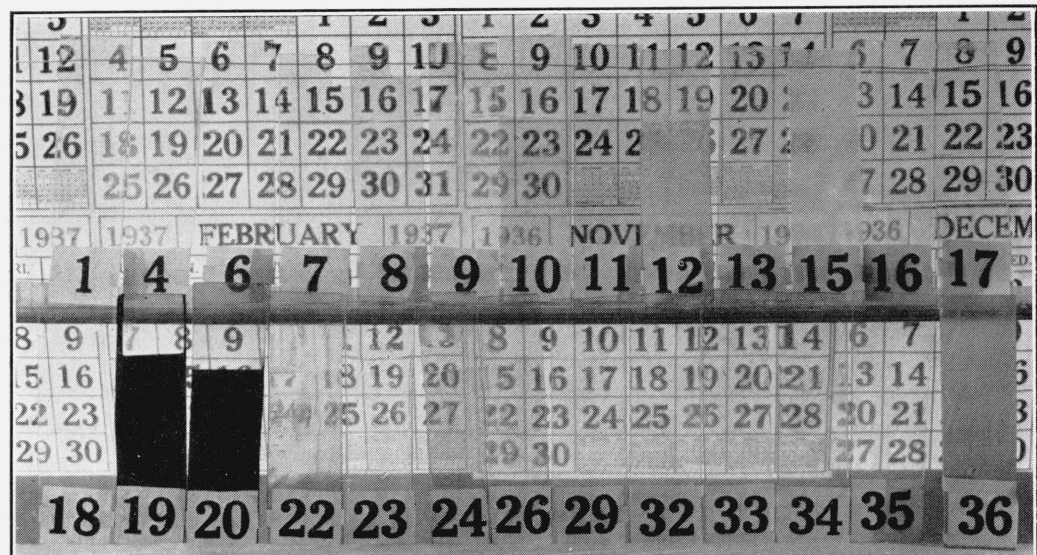

FIGURE 12.-Condition of samples after exposure to carbon-arc light for 500 hours without water spray

\begin{tabular}{|c|c|c|c|c|c|}
\hline $\begin{array}{c}\text { Identifica- } \\
\text { tion } \\
\text { number }\end{array}$ & Material & Sample & $\begin{array}{c}\text { Identifica- } \\
\text { tion } \\
\text { number }\end{array}$ & Material & Sample \\
\hline $\begin{array}{r}1 \\
4 \\
6 \\
7 \\
8 \\
9 \\
10 \\
11 \\
12 \\
13 \ldots \ldots \\
15 \ldots \ldots \\
16 \ldots \ldots \\
17 \\
18\end{array}$ & \begin{tabular}{|} 
Cellulose acetate \\
do do do do do \\
Ethose nitrate \\
Ethylcellulose \\
Acrylate resin \\
do do \\
do
\end{tabular} & $\begin{array}{l}A 1 \\
B 1 \\
B 3 \\
C 1 \\
C 3 \\
D 1 \\
E 1 \\
F^{\prime} 1 \\
G 1 \\
H 1 \\
J 1 \\
J 2 \\
K 1 \\
K 2\end{array}$ & $\begin{array}{l}19 \\
20 \\
22 \\
23 \\
24 \\
26 \\
29 \\
32 \\
33 \\
34 \\
35 \\
36\end{array}$ & $\begin{array}{l}\text { Vinyl chloride-acetate } \\
\text { resin. } \\
\text { Vinyl acetal resin } \\
\text { Cellulose acetobutyrate } \\
\text { Vinyl acetal resin } \\
\text { Glyceryl-phthalate resin } \\
\text { Cellulose acetate } \\
\text { Acrylate resin } \\
\text { Glyceryl-phthalate resin }\end{array}$ & $\begin{array}{l}L 1 \\
\text { L2 } \\
M 1 \\
\text { S1 } \\
\text { N1 } \\
O 1 \\
B 6 \\
B 9 \\
B 4 \\
B 5 \\
K 5 \\
T 1\end{array}$ \\
\hline
\end{tabular}


the water spray was employed. The data for light transmission after 500 hours of exposure, shown in tables 9 and 10 , indicate that the cellulose nitrate and vinyl chloride-acetate resin samples are deteriorated more rapidly in the drier and warmer condition. Figure 12 shows the condition of the specimens after 500 hours of exposure. The unexposed portion is at the top of each specimen in the photograph. Sample J1, an acrylate resin, was quite markedly affected by the higher temperature, and became translucent because of surface roughening.

TABLE 10.-Accelerated aging of transparent plastics by carbon-arc light without water spray

\begin{tabular}{|c|c|c|c|c|c|c|}
\hline \multirow{2}{*}{ Material } & \multirow{2}{*}{$\begin{array}{l}\text { Sam- } \\
\text { ple }\end{array}$} & \multicolumn{2}{|c|}{$\begin{array}{l}\text { White-light } \\
\text { transmission }\end{array}$} & \multicolumn{2}{|c|}{ Haze value } & \multirow{2}{*}{ Remarks on condition at $500 \mathrm{hr}$} \\
\hline & & Initial & $500 \mathrm{hr}$ & Initial & $500 \mathrm{hr}$ & \\
\hline $\begin{array}{l}\text { Cellulose acetate } \\
\text { Do }{ }^{-} \\
\text {Do Do } \\
\text { Do } \\
\text { Do }\end{array}$ & $\begin{array}{l}A 1 \\
B 1 \\
B 3 \\
B 4 \\
B 5\end{array}$ & \begin{tabular}{r|} 
Percent \\
89.2 \\
91.5 \\
91.7 \\
89.1 \\
88.3
\end{tabular} & \begin{tabular}{|} 
Percent \\
90.8 \\
91.8 \\
91.9 \\
87.6 \\
87.0
\end{tabular} & \begin{tabular}{|r} 
Percent \\
3.8 \\
7.4 \\
3.6 \\
4.5 \\
4.4
\end{tabular} & \begin{tabular}{|r|} 
Percent \\
4.4 \\
8.4 \\
4.0 \\
5.5 \\
5.0
\end{tabular} & $\begin{array}{l}\text { Surface slightly roughened. } \\
\text { No marked change. } \\
\text { Surface slightly roughened. } \\
\text { Do. } \\
\text { Surface slightly roughened; dis- }\end{array}$ \\
\hline $\begin{array}{l}\text { Do } \\
\text { Do } \\
\text { Do- } \\
\text { Do } \\
\text { Do }\end{array}$ & $\begin{array}{l}B 6 \\
B 8 \\
C 1 \\
C S \\
D 1\end{array}$ & $\begin{array}{l}91.3 \\
90.6 \\
88.5 \\
82.3 \\
77.4\end{array}$ & $\begin{array}{l}91.8 \\
90.8 \\
90.2 \\
84.3 \\
86.6\end{array}$ & $\begin{array}{r}3.2 \\
3.8 \\
6.0 \\
10.0 \\
7.0\end{array}$ & $\begin{array}{r}4.0 \\
4.1 \\
6.0 \\
10.0 \\
9.3\end{array}$ & $\begin{array}{l}\text { Surface slightly roughened. } \\
\text { Do. } \\
\text { Do. } \\
\text { Do. } \\
\text { Blue dye faded; cracked. }\end{array}$ \\
\hline Cellulose acetobutyrate.. & S1 & 92.8 & 91.8 & 5.5 & 4.1 & Warped; no marked change. \\
\hline $\begin{array}{l}\text { Cellulose nitrate } \\
\text { Do }\end{array}$ & $\begin{array}{l}E 1 \\
F 1\end{array}$ & $\begin{array}{l}91.7 \\
85.2\end{array}$ & $\begin{array}{l}81.4 \\
73.2\end{array}$ & $\begin{array}{l}3.8 \\
3.6\end{array}$ & $\begin{array}{l}6.9 \\
4.1\end{array}$ & $\begin{array}{l}\text { Discolored brown; cracked. } \\
\text { Discolored brown. }\end{array}$ \\
\hline $\begin{array}{l}\text { Ethylcellulose } \\
\text { Do } \\
\text { Do }\end{array}$ & $\begin{array}{l}\text { G1 } \\
H 1 \\
I 1\end{array}$ & $\begin{array}{l}82.7 \\
85.6 \\
91.4\end{array}$ & $\begin{array}{l}83.1 \\
84.4 \\
90.6\end{array}$ & $\begin{array}{r}26.6 \\
9.9 \\
6.1\end{array}$ & $\begin{array}{l}29.6 \\
10.2 \\
(\mathrm{a})\end{array}$ & $\begin{array}{l}\text { Cracked badly and discolored. } \\
\text { No marked change. } \\
\text { Cracked badly and became } \\
\text { friable. }\end{array}$ \\
\hline $\begin{array}{l}\text { Acrylate resin } \\
\text { Do } \\
\text { Do } \\
\text { Do } \\
\text { Do }\end{array}$ & $\begin{array}{l}J 1 \\
J 2 \\
K 1 \\
K 2 \\
K 5\end{array}$ & $\begin{array}{l}93.7 \\
93.7 \\
94.0 \\
94.4 \\
94.2\end{array}$ & $\begin{array}{l}93.7 \\
93.3 \\
93.1 \\
94.3 \\
93.8\end{array}$ & $\begin{array}{r}6.1 \\
\text { b } 6.1 \\
3.6 \\
1.4 \\
1.6\end{array}$ & $\begin{array}{r}10.6 \\
\text { b } 4.7 \\
3.5 \\
1.9 \\
1.4\end{array}$ & $\begin{array}{l}\text { Surface badly pebbled. } \\
\text { No marked change. } \\
\text { Slightly yellowed. } \\
\text { No marked change. } \\
\text { Do. }\end{array}$ \\
\hline $\begin{array}{l}\text { Vinyl chloride-acetate resin } \\
\text { Do }\end{array}$ & $\begin{array}{l}L 1 \\
L 2\end{array}$ & $\begin{array}{l}82.6 \\
80.3\end{array}$ & $\begin{array}{l}\text { ca. } 0 \\
\text { ca. } 0\end{array}$ & $\begin{array}{l}5.0 \\
8.7\end{array}$ & $|-\ldots-1|$ & $\begin{array}{l}\text { Opaque; discolored purple. } \\
\text { Do. }\end{array}$ \\
\hline $\begin{array}{l}\text { Vinyl acetal resin } \\
\text { Do }\end{array}$ & $\begin{array}{l}M 1 \\
\text { N1 }\end{array}$ & $\begin{array}{l}88.7 \\
85.6\end{array}$ & $\begin{array}{l}85.5 \\
83.0\end{array}$ & $\begin{array}{l}3.9 \\
9.5\end{array}$ & $\begin{array}{r}7.8 \\
10.8\end{array}$ & $\begin{array}{l}\text { Discolored yellow. } \\
\text { Surface roughened; discolored } \\
\text { yellow. }\end{array}$ \\
\hline $\begin{array}{l}\text { Glyceryl-phthalate resin } \\
\text { Do }\end{array}$ & $\begin{array}{l}01 \\
T 1\end{array}$ & $\begin{array}{l}85.8 \\
66.2\end{array}$ & $\begin{array}{l}81.0 \\
65.0\end{array}$ & $\begin{array}{l}5.2 \\
(c)\end{array}$ & $\begin{array}{l}5.8 \\
(c)\end{array}$ & $\begin{array}{l}\text { Discolored brown. } \\
\text { Discolored yellow. }\end{array}$ \\
\hline
\end{tabular}

a Specimen broke before these values could be determined.

b Specimen slightly prismatic, making haze measurement doubtful.

c Surfaces of specimen unpolished.

The haze values in tables 7 and 10 show that the results of the accelerated test do not indicate the same relative order of stability as is found upon exposure out-of-doors. The two cellulose nitrate samples became clouded at about the same rate on the roof, whereas $E 1$ broke down more rapidly than $F 1$ in the accelerated test. Similar discrepancies are noted for the ethylcellulose and vinyl acetal resins. The amount of discoloration of the samples by the carbon-arc light can be judged from the data in table 11 for light transmission using various color filters. There was a considerable drop in the light transmitted, 
using the green and blue filters, for the cellulose nitrate samples and the glyceryl-phthalate resin 01. A slight drop was also noted for acrylate resin $K 1$. On the other hand, the light transmission, using the green filter, showed a marked increase after 500 hours of exposure to ultraviolet light for those samples which contained blue dye, notably for cellulose acetate $D 1$.

TABLE 11.-Effect of accelerated aging of transparent plastics by carbon-arc light without water spray on light transmission using various color filters

\begin{tabular}{|c|c|c|c|c|c|c|c|}
\hline \multirow{3}{*}{ Material } & \multirow{3}{*}{$\begin{array}{c}\text { Sam- } \\
\text { ple }\end{array}$} & \multicolumn{6}{|c|}{ Color transmission } \\
\hline & & \multicolumn{2}{|c|}{ Red filter a } & \multicolumn{2}{|c|}{ Green filter $b$} & \multicolumn{2}{|c|}{ Blue filter $\circ$} \\
\hline & & Initial & $500 \mathrm{hr}$ & Initial & $500 \mathrm{hr}$ & Initial & $500 \mathrm{hr}$ \\
\hline 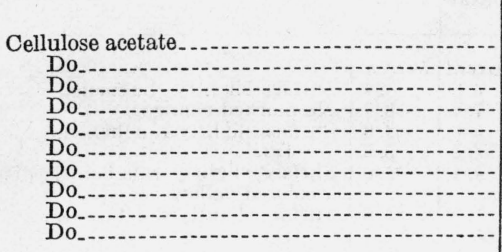 & $\begin{array}{l}A 1 \\
B 1 \\
B 3 \\
B 4 \\
B 5 \\
B 6 \\
B 8 \\
C 1 \\
C 3 \\
D 1\end{array}$ & \begin{tabular}{r|} 
Percent \\
91.3 \\
91.7 \\
92.3 \\
89.1 \\
89.6 \\
92.1 \\
91.1 \\
90.6 \\
86.7 \\
84.9
\end{tabular} & \begin{tabular}{|r|} 
Percent \\
91.6 \\
92.1 \\
92.2 \\
88.8 \\
88.7 \\
92.1 \\
91.3 \\
91.2 \\
87.5 \\
88.2
\end{tabular} & \begin{tabular}{r|} 
Percent \\
87.3 \\
89.3 \\
90.2 \\
86.2 \\
87.0 \\
89.8 \\
91.4 \\
86.3 \\
78.7 \\
75.7
\end{tabular} & \begin{tabular}{r|} 
Percent \\
89.5 \\
90.5 \\
90.8 \\
85.7 \\
84.7 \\
90.6 \\
89.2 \\
88.5 \\
81.3 \\
84.0
\end{tabular} & \begin{tabular}{|r|} 
Percent \\
89.4 \\
89.8 \\
90.0 \\
86.2 \\
87.4 \\
89.6 \\
89.0 \\
87.8 \\
81.8 \\
82.6
\end{tabular} & $\begin{array}{r}\text { Percent } \\
90.6 \\
91.2 \\
91.4 \\
86.6 \\
85.6 \\
91.4 \\
90.2 \\
89.6 \\
84.4 \\
84.6\end{array}$ \\
\hline Cellulose acetobutyrate.... & S1 & 92.8 & 91.8 & 91.2 & 90.7 & 91.4 & 90.6 \\
\hline Cellulose nitrate- & $\begin{array}{l}E 1 \\
F 1\end{array}$ & $\begin{array}{l}92.0 \\
83.8\end{array}$ & $\begin{array}{l}90.7 \\
82.8\end{array}$ & $\begin{array}{l}89.8 \\
84.9\end{array}$ & $\begin{array}{l}74.2 \\
66.7\end{array}$ & $\begin{array}{l}89.4 \\
85.8\end{array}$ & $\begin{array}{l}72.0 \\
65.6\end{array}$ \\
\hline $\begin{array}{l}\text { Ethylcellulose } \\
\text { Do } \\
\text { Do }\end{array}$ & $\begin{array}{l}G 1 \\
H 1 \\
I 1\end{array}$ & $\begin{array}{l}86.1 \\
86.7 \\
92.2\end{array}$ & $\begin{array}{l}86.2 \\
86.0 \\
\text { (d) }\end{array}$ & $\begin{array}{l}78.2 \\
82.7 \\
89.7\end{array}$ & $\begin{array}{l}80.3 \\
82.6 \\
\text { (d) }\end{array}$ & $\begin{array}{l}76.6 \\
81.6 \\
89.6\end{array}$ & $\begin{array}{l}80.8 \\
82.4 \\
(\mathrm{~d})\end{array}$ \\
\hline 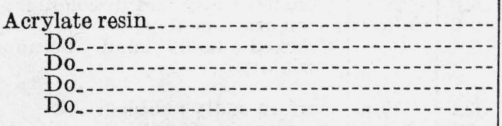 & $\begin{array}{l}J 1 \\
J^{2} \\
K 1 \\
K 2 \\
K 5\end{array}$ & \begin{tabular}{l|}
93.3 \\
93.5 \\
93.2 \\
93.9 \\
93.7
\end{tabular} & $\begin{array}{l}92.9 \\
93.2 \\
93.3 \\
93.7 \\
93.3\end{array}$ & $\begin{array}{l}92.3 \\
92.4 \\
92.6 \\
93.0 \\
93.0\end{array}$ & $\begin{array}{l}92.7 \\
92.3 \\
91.7 \\
93.4 \\
92.7\end{array}$ & $\begin{array}{l}92.8 \\
92.4 \\
92.6 \\
93.4 \\
93.2\end{array}$ & $\begin{array}{l}92.8 \\
92.4 \\
91.4 \\
93.4 \\
92.6\end{array}$ \\
\hline $\begin{array}{l}\text { Vinyl chloride-acetate resin } \\
\text { Do }\end{array}$ & $\begin{array}{l}L 1 \\
L 2\end{array}$ & $\begin{array}{l}87.5 \\
86.3\end{array}$ & $\begin{array}{l}\text { ca. } 0 \\
\text { ca. } 0\end{array}$ & $\begin{array}{l}83.8 \\
77.3\end{array}$ & $\begin{array}{l}\text { ca. } 0 \\
\text { ca. } 0\end{array}$ & $\begin{array}{l}87.2 \\
79.2\end{array}$ & $\begin{array}{l}\text { ca. } 0 \\
\text { ca. } 0\end{array}$ \\
\hline Vinyl acetal resin & $\begin{array}{l}M 1 \\
N 1\end{array}$ & $\begin{array}{l}89.3 \\
86.8\end{array}$ & $\begin{array}{l}88.3 \\
85.7\end{array}$ & $\begin{array}{l}86.2 \\
82.4\end{array}$ & $\begin{array}{l}82.3 \\
80.3\end{array}$ & $\begin{array}{l}85.6 \\
81.4\end{array}$ & $\begin{array}{l}80.4 \\
78.6\end{array}$ \\
\hline $\begin{array}{l}\text { Glyceryl-phthalate resin } \\
\text { Do }\end{array}$ & $\begin{array}{l}O 1 \\
T 1\end{array}$ & $\begin{array}{l}88.5 \\
69.3\end{array}$ & $\begin{array}{l}86.6 \\
70.3\end{array}$ & $\begin{array}{l}81.2 \\
57.2\end{array}$ & $\begin{array}{l}74.8 \\
58.8\end{array}$ & $\begin{array}{l}80.6 \\
62.4\end{array}$ & $\begin{array}{l}76.4 \\
63.0\end{array}$ \\
\hline
\end{tabular}

s Pyrometer red filter.

- No. 61 Wratten filter.

- No. 47 Wratten filter.

d Specimen broke before these values could be determined.

\section{SCRATCH RESISTANCE}

The comparative ease with which transparent organic plastics are scratched is a major obstacle to their substitution for glass in many applications where their toughness and nonsplintering characteristics would be advantageous. However, the plastics vary considerably in scratch resistance, and it is desirable to have a method of measuring this property. The effect of tumbling with sand of a standard grade was tried, but after a short period a polishing action produced by fine fragments tended to undo the action of the coarse grains of sand. Furthermore, it was very difficult to remove the fine dust from the samples preparatory to determining the amount of abrasion by measuring the light transmission. 


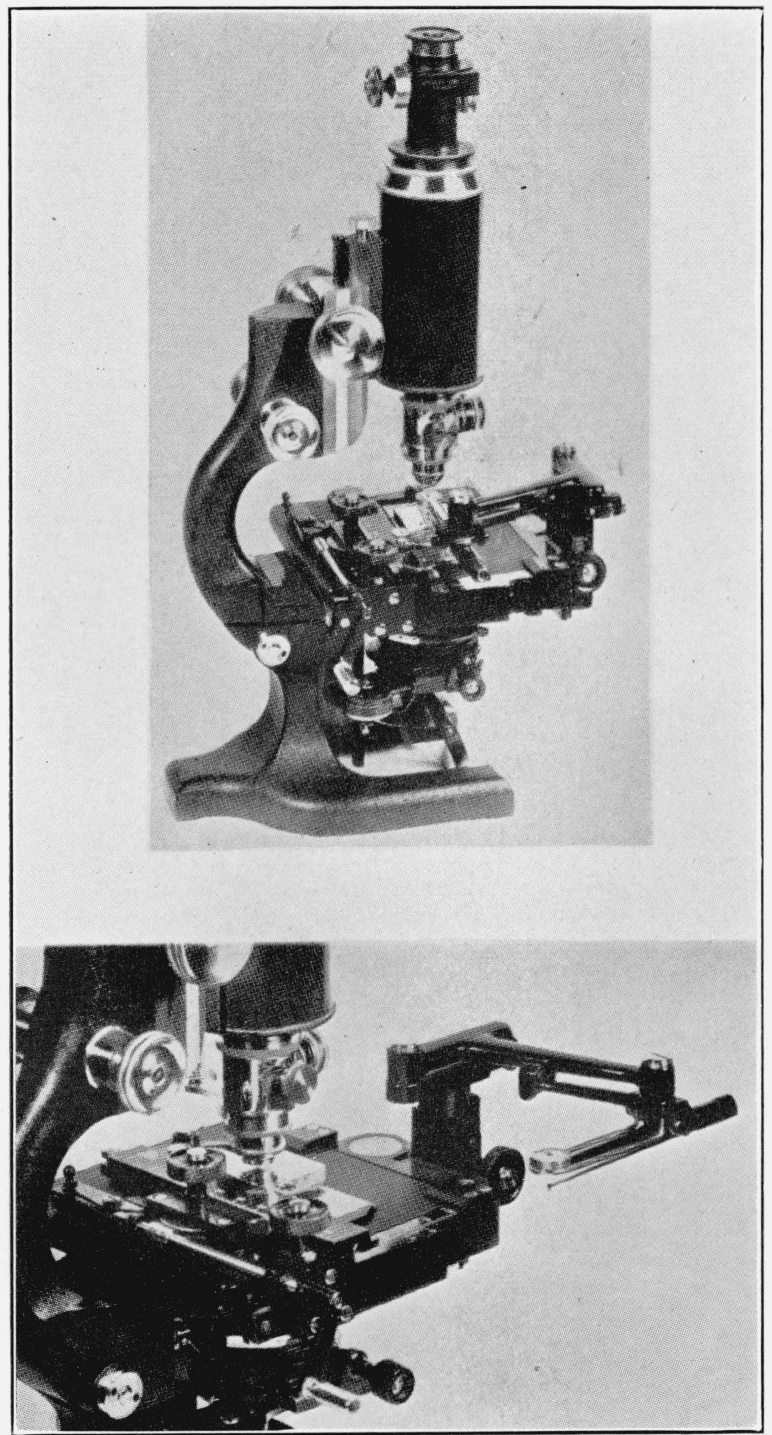

FIGURE 13.-Bierbaum scratch-resistance apparatus.

Above: Diamond tool in scratching position.

Below: Diamond tool swung aside and microscore in position to measure scratch width. 


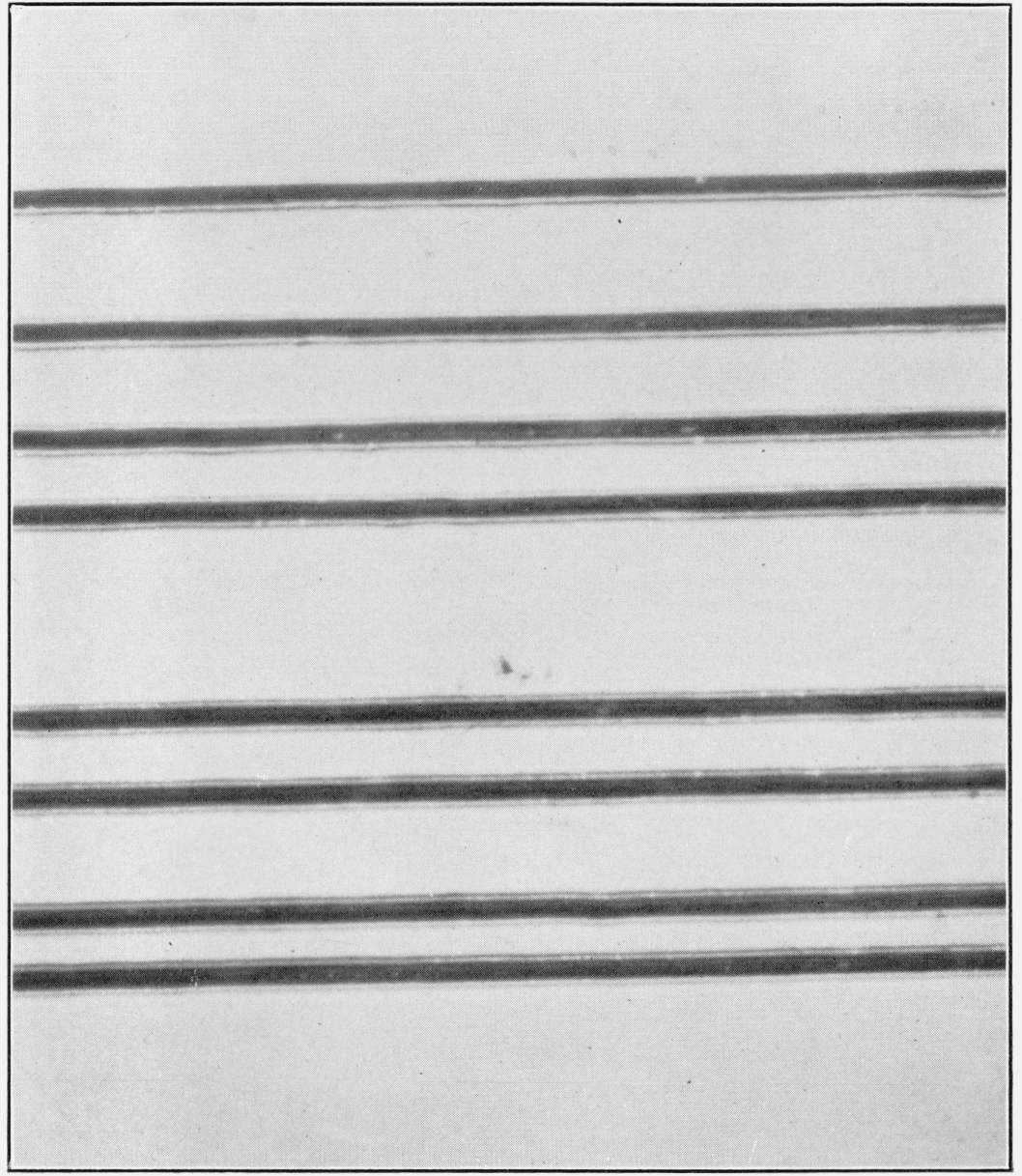

Figure 14. - Scratches on cellulose acetate plastic $(\times 150)$. 
These difficulties are avoided when a sclerometer is used to produce a band of scratches from which the relative resistance of the material can be judged by determining the average width of the scratches. Various types of sclerometers have been developed for use in making scratch tests on metals. These are discussed in detail by O'Neill. ${ }^{1}$

\section{DESCRIPTION OF APPARATUS}

The instrument used in this work on plastics was developed by Bierbaum and is called the Microcharacter (fig. 13). The cutting diamond is in the form of a corner of a cube, mounted so that the diagonal of the cube is normal to the test surface and one edge is in line with the direction of the scratch. The diamond is suspended from a balanced arm pivoted on sapphire bearings. One end of the arm is provided with a spirit level and the other with a 3-gram weight which constitutes the standard load for the diamond point. The diamond is mounted at the small end of a tapered steel spring; the other end of the spring is fastened to the lower side of the suspension area. A vertical rack is provided for raising and lowering the bracket that carries the cutting tool. This bracket is attached to a microscope mechanical stage provided with suitable clamps and screw mechanism to permit the specimen to be moved slowly under the diamond point. The width of the scratch (fig. 14) is measured with a microscope having a calibrated filar micrometer eyepiece. The plastics were conditioned at $21^{\circ} \mathrm{C}$ and 65 -percent relative humidity for at least 24 hours, and the test was conducted under these conditions. The scratch resistance is defined as the quotient of the load in kilograms divided by the square of the scratch width in millimeters.

\section{RESULTS OF SCRATCH-WIDTH MEASUREMENTS}

The data obtained with the Bierbaum Microcharacter on various plastics are shown in table 12. Each value is the average of 15 measurements on 5 scratches, each scratch being measured at 3 points. The speed of the diamond point was approximately 0.2 $\mathrm{mm} / \mathrm{sec}$. To determine whether or not a material was anisotropic, two bands of scratches at right angles to each other were ruled on the specimen. A few cellulose acetates, notably samples $A 3, B 5$, and $C 3$ give some indication of anisotropism. The results show that most of the materials are isotropic as far as scratch resistance is concerned.

The scratch resistance of cellulose acetate varied with the products of different manufacturers, presumably because of differences in types and amounts of plasticizer present. The acrylate resins were the most resistant to scratching of the materials studied.

\footnotetext{
1 H. O'Neill, Hardness of Metals and Its Measurement (Sherwood Press, Cleveland, 1934).
} 
TABLE 12.-Scratch resistance of transparent plastics measured with the Bierbaum Microcharacter

\begin{tabular}{|c|c|c|c|c|c|}
\hline \multirow[b]{2}{*}{ Material } & \multirow[b]{2}{*}{ Sample } & \multirow[b]{2}{*}{$\begin{array}{l}\text { Thick- } \\
\text { ness }\end{array}$} & \multicolumn{3}{|c|}{ Scratch resistance ${ }^{\text {a }}$} \\
\hline & & & $\begin{array}{l}\text { Scratches } \\
\text { ruled } \\
\text { parallel } \\
\text { to length } \\
\text { of sample }\end{array}$ & $\begin{array}{l}\text { Scratches } \\
\text { ruled per- } \\
\text { pendicular } \\
\text { to length } \\
\text { of sample }\end{array}$ & Average \\
\hline 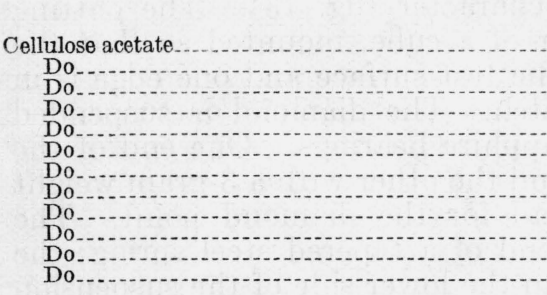 & $\begin{array}{l}A 1 \\
A 2 \\
A 3 \\
B 1 \\
B 3 \\
B 4 \\
B 5 \\
B 6 \\
C 1 \\
C 2 \\
C B \\
D 1\end{array}$ & $\begin{array}{r}\text { Mils } \\
62 \\
90 \\
125 \\
60 \\
60 \\
100 \\
100 \\
60 \\
60 \\
90 \\
125 \\
150\end{array}$ & $\begin{array}{r}\mathrm{kg} / \mathrm{mm}^{2} \\
9.9 \\
11.9 \\
11.1 \\
8.3 \\
8.2 \\
9.3 \\
5.6 \\
7.3 \\
7.6 \\
8.1 \\
7.7 \\
5.7\end{array}$ & $\begin{array}{r}\mathrm{kg} / \mathrm{mm}^{2} \\
9.9 \\
11.8 \\
9.2 \\
8.1 \\
8.1 \\
9.2 \\
6.9 \\
7.9 \\
7.1 \\
7.0 \\
7.3 \\
5.0\end{array}$ & $\begin{array}{r}\mathrm{kg} / \mathrm{mm}^{2} \\
9.9 \\
11.9 \\
10.2 \\
8.2 \\
8.2 \\
9.3 \\
6.3 \\
7.6 \\
7.4 \\
7.6 \\
7.5 \\
5.4\end{array}$ \\
\hline Cellulose acetobutyrate..... & S1 & 40 & 4.5 & 4.5 & 4. 5 \\
\hline $\begin{array}{l}\text { Cellulose nitrate } \\
\text { Do }\end{array}$ & $\begin{array}{l}E 1 \\
F 1\end{array}$ & $\begin{array}{l}60 \\
62\end{array}$ & $\begin{array}{l}10.0 \\
10.3\end{array}$ & $\begin{array}{l}9.9 \\
9.9\end{array}$ & $\begin{array}{l}10.0 \\
10.1\end{array}$ \\
\hline $\begin{array}{l}\text { Ethylcellulose } \\
\text { Do } \\
\text { Do }\end{array}$ & $\begin{array}{l}G 1 \\
H 1 \\
I 1\end{array}$ & $\begin{array}{l}60 \\
30 \\
40\end{array}$ & $\begin{array}{l}5.6 \\
6.3 \\
4.0\end{array}$ & $\begin{array}{l}5.5 \\
6.2 \\
4.5\end{array}$ & $\begin{array}{l}5.6 \\
6.3 \\
4.3\end{array}$ \\
\hline $\begin{array}{l}\text { Acrylate resin } \\
\text { Do } \\
\text { Do } \\
\text { Do }\end{array}$ & $\begin{array}{l}J 1 \\
J 2 \\
K 1 \\
K 5\end{array}$ & $\begin{array}{r}70 \\
65 \\
120 \\
120\end{array}$ & $\begin{array}{l}15.0 \\
18.4 \\
15.1 \\
16.8\end{array}$ & $\begin{array}{l}15.0 \\
18.1 \\
14.9 \\
16.4\end{array}$ & $\begin{array}{l}15.0 \\
18.3 \\
15.0 \\
16.6\end{array}$ \\
\hline $\begin{array}{l}\text { Vinyl chloride-acetate resin } \\
\text { Do } \\
\text { Do }\end{array}$ & $\begin{array}{l}L 1 \\
L 2 \\
L S\end{array}$ & $\begin{array}{r}50 \\
100 \\
100\end{array}$ & $\begin{array}{r}10.3 \\
9.8 \\
10.7\end{array}$ & $\begin{array}{r}10.1 \\
9.6 \\
10.6\end{array}$ & $\begin{array}{r}10.2 \\
9.7 \\
10.7\end{array}$ \\
\hline Vinyl acetal resin & $N 1$ & 100 & 7.0 & 7.0 & 7. 0 \\
\hline Glyceryl-phthalate resin.... & 01 & 125 & 14.0 & & 14.0 \\
\hline Styrene... & $R 1$ & 80 & 10.6 & 10.4 & 10.5 \\
\hline
\end{tabular}

a Scratch resistance is defined as the quotient of the load in kilograms divided by the square of the scratch width in millimeters.

A value of 14.8 for the scratch resistance of acrylate resin sample $K 1$ was obtained when a 6 -gram load on the diamond point was used. Comparison of this value measured with a 6-gram load with the one in table 12 obtained with a 3-gram load, namely, 15.0, shows that the calculated scratch resistance value is substantially independent of the load used. This would be expected to be true, since the diamond tool is of such shape that the scratches made with different loads are geometrically similar. The widths of the microcuts obtained with the 3 - and 6-gram loads for this acrylate resin were, respectively, 14.2 and 20.3 microns.

\section{INDENTATION HARDNESS}

A number of instruments for measuring indentation hardness previously developed for use with metals have been applied to the determination of the so-called hardness of plastics, including the Brinell, Martens, Rockwell, Vickers, and Shore machines. Table 13 presents the results of measurements made on unconditioned samples of plastics with some of these instruments. There is relatively good agree- 


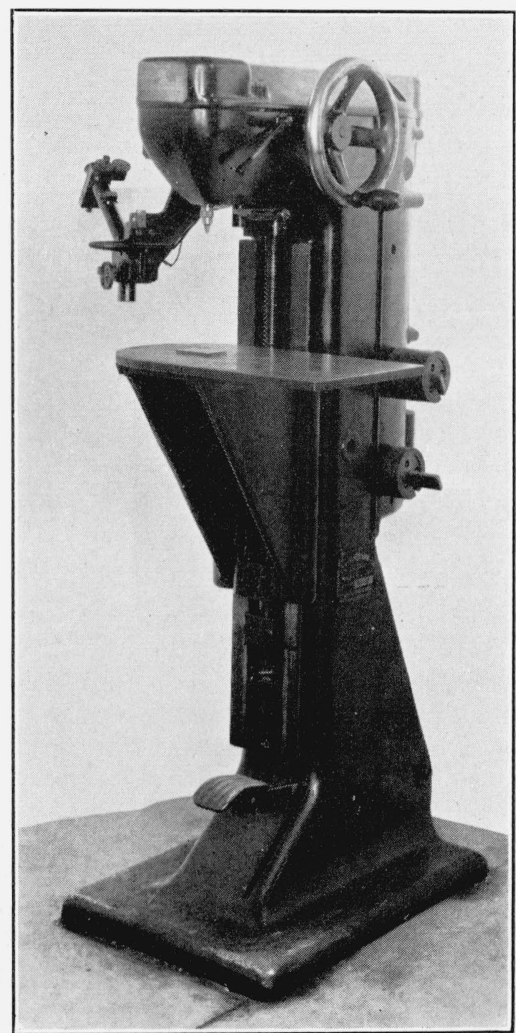

Figure 15.-Vickers hardness testing machine. 


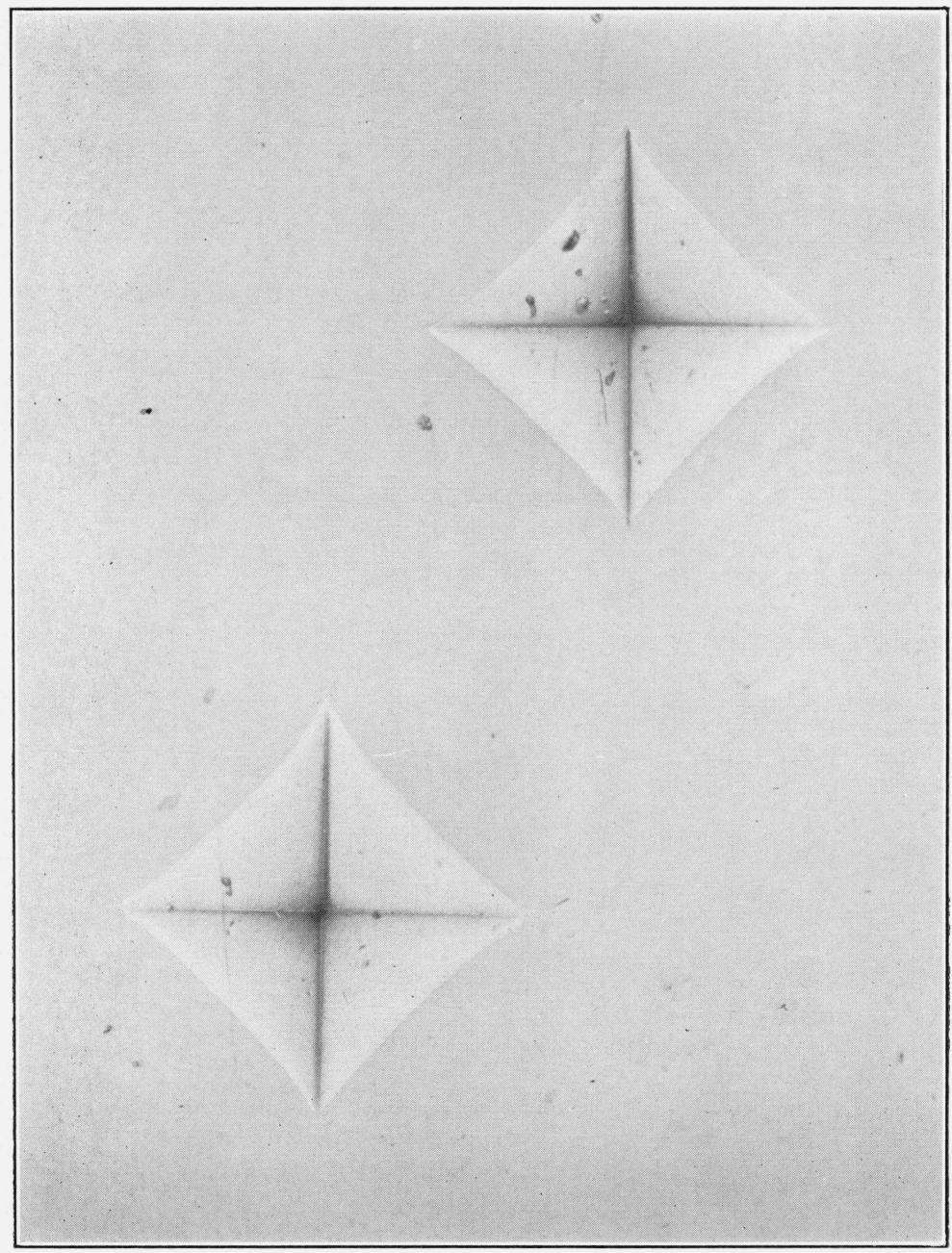

FiguRe 16.-Pyramidal indentations on vinyl resin plastic $(X \% O)$. 
ment between the degrees of hardness indicated by the Vickers, Rockwell, and Brinell machines. The Shore scleroscope is not considered very satisfactory because the hardness values indicated for the plastics were all much higher than those for a mild-steel specimen, the Brinell hardness of which was about 10 times that of the plastics. The data in the last two columns in table 13 show the effect of time of application of the load on the hardness values obtained. The relatively soft plastics undergo very little increase in indentation after 30 seconds loading time, but for the materials above Brinell number 15 a considerable effect on the area of the indentation is noted.

TABLE 13.-Hardness of transparent plastics as measured by various instruments

\begin{tabular}{|c|c|c|c|c|c|c|c|}
\hline Material & $\begin{array}{l}\text { Sam- } \\
\text { ple }\end{array}$ & $\begin{array}{c}\text { Thick- } \\
\text { ness }\end{array}$ & $\begin{array}{l}\text { Shore } \\
\text { sclero- } \\
\text { scope } \\
\text { number a }\end{array}$ & $\begin{array}{c}\text { Vickers } \\
\text { number } \mathrm{b}\end{array}$ & $\begin{array}{l}\text { Rock- } \\
\text { well } \\
\text { number c } \\
\text { (15-T } \\
\text { scale) }\end{array}$ & $\begin{array}{c}\text { Brinell } \\
\text { number d } \\
(30 \text { sec })\end{array}$ & $\begin{array}{l}\text { Brinell } \\
\text { number } \\
(3 \mathrm{~min})\end{array}$ \\
\hline $\begin{array}{l}\text { Cellulose acetate } \\
\text { Do } \\
\text { Do } 0 . \\
\text { Do Do } \\
\text { Do }\end{array}$ & $\begin{array}{l}A 1 \\
B 1 \\
B 2 \\
C 1 \\
C 3\end{array}$ & $\begin{array}{r}\text { Mils } \\
62 \\
60 \\
90 \\
60 \\
125\end{array}$ & $\begin{array}{l}57 \\
53 \\
61 \\
53 \\
54\end{array}$ & $\begin{array}{r}8.7 \\
11.0 \\
8.4 \\
7.0 \\
6.2\end{array}$ & $\begin{array}{r}15.1 \\
16.2 \\
16.0 \\
9.9 \\
11.2\end{array}$ & $\begin{array}{l}13.0 \\
13.1 \\
13.9 \\
11.5 \\
10.9\end{array}$ & $\begin{array}{l}12.4 \\
12.6 \\
12.3 \\
11.4 \\
11.0\end{array}$ \\
\hline $\begin{array}{l}\text { Cellulose nitrate } \\
\text { Do }\end{array}$ & $\begin{array}{l}E 1 \\
F 1\end{array}$ & $\begin{array}{l}60 \\
62\end{array}$ & $\begin{array}{l}63 \\
60\end{array}$ & $\begin{array}{l}12.7 \\
11.7\end{array}$ & $\begin{array}{l}29.7 \\
23.2\end{array}$ & $\begin{array}{l}16.6 \\
15.8\end{array}$ & $\begin{array}{l}15.8 \\
15.0\end{array}$ \\
\hline Ethylcellulose & G1 & 60 & 50 & 6.3 & 7.7 & 10.6 & 10.6 \\
\hline $\begin{array}{l}\text { Acrylate resin } \\
\text { Do } \\
\text { Do }\end{array}$ & $\begin{array}{l}J 1 \\
J 2 \\
K 1\end{array}$ & $\begin{array}{r}70 \\
65 \\
120\end{array}$ & $\begin{array}{l}73 \\
84 \\
75\end{array}$ & $\begin{array}{l}18.4 \\
24.0 \\
15.0\end{array}$ & $\begin{array}{l}39.5 \\
81.6 \\
31.5\end{array}$ & $\begin{array}{l}17.5 \\
27.4 \\
16.0\end{array}$ & $\begin{array}{l}14.7 \\
20.9 \\
14.5\end{array}$ \\
\hline $\begin{array}{l}\text { Vinyl chloride-acetate resin } \\
\text { Vinyl acetal resin. } \\
\text { Styrene resin }\end{array}$ & $\begin{array}{l}L 1 \\
M 1 \\
R 1\end{array}$ & $\begin{array}{l}50 \\
63 \\
80\end{array}$ & $\begin{array}{l}62 \\
45 \\
65\end{array}$ & $\begin{array}{r}16.2 \\
3.0 \\
20.0\end{array}$ & $\begin{array}{l}32.7 \\
(f) \\
65.0\end{array}$ & $\begin{array}{l}16.4 \\
(f) \\
20.0\end{array}$ & ${ }^{(f)} \begin{array}{r}14.0 \\
16.4\end{array}$ \\
\hline $\begin{array}{l}\text { Phenol-formaldahyde resin } \\
\text { Plate glass.... } \\
\text { Mild steel }\end{array}$ & $\begin{array}{l}U 1 \\
X 1\end{array}$ & $\begin{array}{r}125 \\
85 \\
1,000\end{array}$ & $\begin{array}{r}80 \\
121 \\
25\end{array}$ & $\begin{array}{c}12.6 \\
\mathrm{~g} 159\end{array}$ & 15.5 & h 159 & 15. 3 \\
\hline
\end{tabular}

a Rebound, measured on an arbitrary scale of 140 , of a bammer with a diamond striking point falling freely from a height of approximately $3 / 4$ inch; model $D$ instrument.

b 5 -kg load applied on a diamond pyramid for 7 seconds.

- 15-kg load applied on a ball of $1 / 16$ inch diameter for 30 seconds; Rockwell superficial hardness tester.

d 15-kg load applied on a ball of $1 / 16$ inch diameter for 30 seconds (usual Brinell time).

i 15 -kg load applied on a ball of $1 / 16$ inch diameter for 3 minutes.

I Too soft to measure.

g 50 -kg load.

h $3,000-\mathrm{kg}$ load on a ball of $10 \mathrm{~mm}$ diameter.

The Vickers hardness-testing machine (fig. 15) was used for making a more detailed study of indentation hardness of plastics. The indenting tool in this instrument is a diamond in the form of a square pyramid, having an angle between opposite faces of $136^{\circ}$, the value obtained therewith being substantially independent of the testing load. The lengths of the diagonals of the indentation (fig. 16) made with this tool are more readily measured than the diameter of the indentation made by a spherical tool. A load of 5 kilograms was used. The machine is so constructed that the load is applied slowly and progressively to the test specimen, remains for a given time, and is then automatically removed. The lengths of the diagonals of the indentation are measured by means of a micrometer ocular in the microscope attached to the apparatus. The Vickers hardness number is the quotient of the applied load, in kilograms, divided by the pyramidal area of the impression in square millimeters. The plastics 
were conditioned at $21^{\circ} \mathrm{C}$ and 65 -percent relative humidity for not less than 24 hours prior to testing.

The effects of variations in the time of application of full load on the values obtained for Vickers hardness numbers are shown in table 14. The time was found to be an important factor in this test as in the Brinell test. A more detailed study of the Vickers hardness of the transparent plastics was made on the same samples used for the scratch resirtance test. A full load time of 10 seconds was selected. The values obtained are shown in table 15. Each value given in tables 14 and 15 is the average of four determinations. Lack of uniformity in the sheet is believed to be responsible in large part for the differences noted for the indentation hardness of a given plastic sample in the two tables.

TABLE 14.-Variation of Vickers hardness number with time of loading

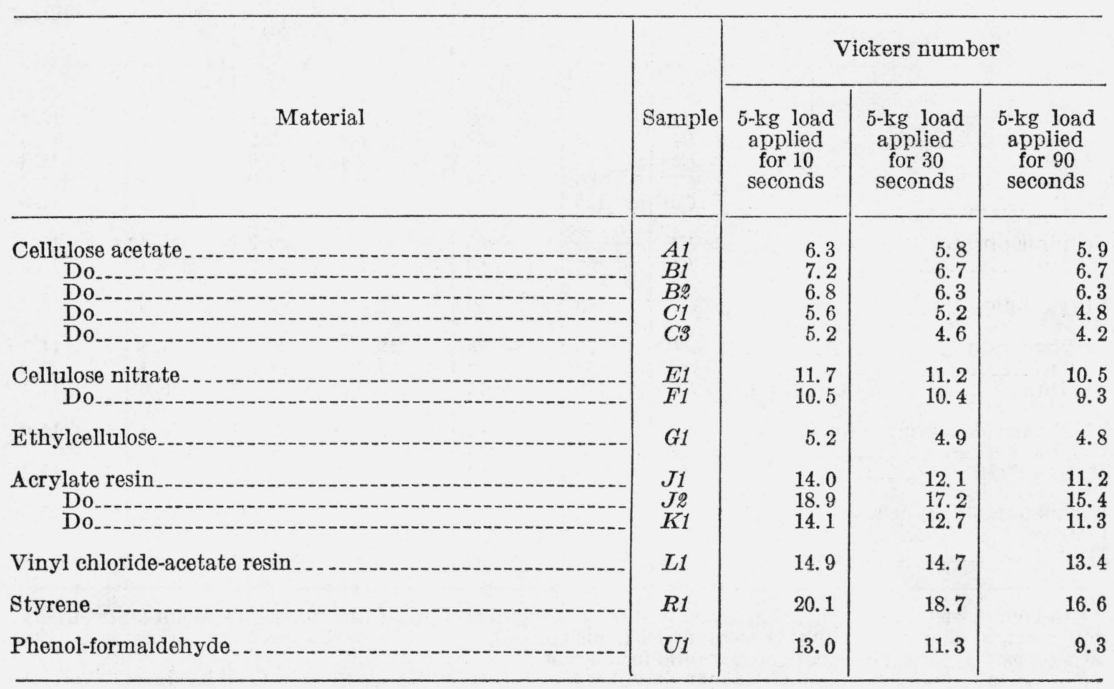


TABLE 15.-Vickers indentation hardness numbers of various transparent plastics

(Samples conditioned at $21^{\circ} \mathrm{C}$ and 65 -percent relative humidity; 5 -kg load applied for 10 seconds.)

\begin{tabular}{|c|c|c|c|}
\hline Material & Sample & $\begin{array}{l}\text { Thick- } \\
\text { ness }\end{array}$ & $\begin{array}{l}\text { Vickers } \\
\text { number }\end{array}$ \\
\hline 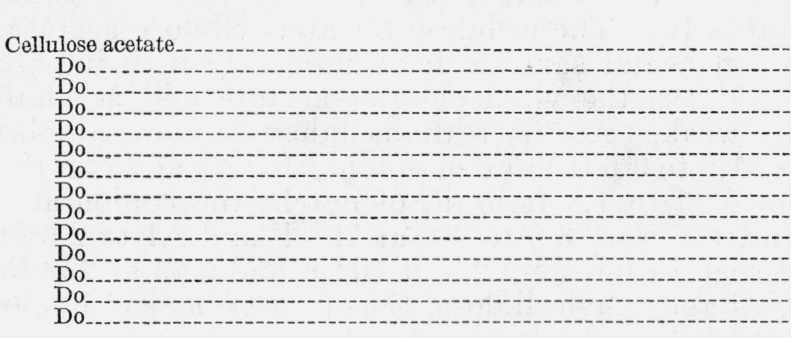 & $\begin{array}{l}A 1 \\
A 2 \\
A 3 \\
B 1 \\
B 2 \\
B 3 \\
B 4 \\
B 5 \\
B 6 \\
B 9 \\
C 1 \\
C 2 \\
C 3 \\
D 1\end{array}$ & $\begin{array}{r}\text { Mils } \\
62 \\
90 \\
125 \\
60 \\
90 \\
60 \\
60 \\
60 \\
60 \\
60 \\
60 \\
90 \\
125 \\
150\end{array}$ & $\begin{array}{l}6.9 \\
7.7 \\
7.1 \\
7.9 \\
6.6 \\
6.8 \\
7.0 \\
4.3 \\
6.2 \\
6.6 \\
5.6 \\
5.5 \\
5.2 \\
7.0\end{array}$ \\
\hline Cellulose acetobutyrate_........- & S1 & 40 & 4.8 \\
\hline $\begin{array}{l}\text { Cellulose nitrate. } \\
\text { Do }\end{array}$ & $\begin{array}{l}E 1 \\
F 1\end{array}$ & $\begin{array}{l}60 \\
62\end{array}$ & $\begin{array}{l}11.6 \\
10.5\end{array}$ \\
\hline $\begin{array}{l}\text { Ethylcellulose } \\
\text { Do } \\
\text { Do }\end{array}$ & $\begin{array}{l}\text { G1 } \\
H 1 \\
I 1\end{array}$ & $\begin{array}{l}60 \\
30 \\
40\end{array}$ & $\begin{array}{l}5.6 \\
8.0 \\
4.6\end{array}$ \\
\hline $\begin{array}{l}\text { Acrylate resin } \\
\text { Do } \\
\text { Do } \\
\text { Do }\end{array}$ & $\begin{array}{l}J 1 \\
J 2 \\
K 1 \\
K 6\end{array}$ & $\begin{array}{r}70 \\
65 \\
120 \\
120\end{array}$ & $\begin{array}{l}15.4 \\
19.2 \\
13.6 \\
16.7\end{array}$ \\
\hline $\begin{array}{l}\text { Vinyl chloride-acetate resin } \\
\text { Do Do } \\
\text { Do }\end{array}$ & $\begin{array}{l}L 1 \\
L 2 \\
L S\end{array}$ & $\begin{array}{r}50 \\
100 \\
100\end{array}$ & $\begin{array}{l}15.3 \\
15.0 \\
15.0\end{array}$ \\
\hline $\begin{array}{l}\text { Vinyl acetal resin } \\
\text { Do }\end{array}$ & $\begin{array}{l}M 1 \\
N 1\end{array}$ & $\begin{array}{r}63 \\
100\end{array}$ & $\begin{array}{r}\text { ca. } 0.5 \\
11.0\end{array}$ \\
\hline $\begin{array}{l}\text { Glyceryl-phthalate resin } \\
\text { Styrene resin } \\
\text { Phenol-formaldehyde resin }\end{array}$ & $\begin{array}{l}O 1 \\
R 1 \\
U 1\end{array}$ & $\begin{array}{r}125 \\
80 \\
125\end{array}$ & $\begin{array}{l}27.1 \\
19.8 \\
13.0\end{array}$ \\
\hline
\end{tabular}

The glyceryl-phthalate resin was the most resistant to indentation of the materials tested; the cellulose derivatives were indented more readily than the resins with the exception of the vinyl acetal sheets, one of which was very soft. Some evidence was also obtained in measurements of the indentation diagonals that a few of the cellulose acetate sheets were anisotropic, but the variations in the two directions were not large enough to warrant reporting in detail.

It is interesting to compare the Vickers hardness numbers in table 15 with the scratch-resistance data in table 12. Good correlation is evident for the cellulose nitrate, ethylcellulose, and acrylate resin plastics. However, the scratch resistance values for the vinyl and styrene resins are much lower than the indentation values, and for the cellulose acetate samples, the two coefficients are not similar. It is, therefore, believed to be impractical to substitute the better-known and more-rapid indentation-hardness measurement for scratchresistance data obtained with a sclerometer.

\section{IMPACT STRENGTH}

\section{CHARPY TEST}

The resistance of the transparent plastics to impact was determined with a Charpy impact machine and by a falling-ball method. For the Charpy tests, two sets of notched specimens 0.5 by 2.5 inches were 
prepared. The notch, located at the center of the specimen, was 0.1 inch deep and was produced with an ordinary $60^{\circ}$ triangular file. One set was tested for impact strength at $70^{\circ} \mathrm{F}$ and the other at about $25^{\circ} \mathrm{F}$. The samples were broken individually and not as a composite specimen. The capacity of the Charpy machine (fig. 17) was $2.9 \mathrm{ft} \mathrm{lb}$, while its striking velocity was about $8 \mathrm{ft} / \mathrm{sec}$. The results of these tests are shown in table 16. The cellulose nitrate, cellulose acetate, ethylcellulose and vinyl acetal samples have relatively high impact strength at $70^{\circ} \mathrm{F}$, whereas the vinyl chloride-acetate and acrylate resins were relatively weak. At $70^{\circ} \mathrm{F}$ the cellulose acetate samples gave impact values of 1.9 to $3.6 \mathrm{ft} \mathrm{lb} / \mathrm{in}$. of notch, whereas at $25^{\circ} \mathrm{F}$ the strength varied from 0.25 to $1.5 \mathrm{ft} \mathrm{lb} /$ in. of notch; the comparable figures for cellulose nitrate were 3.8 to 4.4 at $70^{\circ} \mathrm{F}$ and 2.1 to 2.6 at $25^{\circ} \mathrm{F}$, and for vinyl acetal resin were 2.9 at $70^{\circ} \mathrm{F}$ and 0.65 at $25^{\circ} \mathrm{F}$. For the acrylate resins and ethylcellulose, the strength at $25^{\circ} \mathrm{F}$ was about 80 percent of the values observed at $70^{\circ} \mathrm{F}$.

\section{FALLING-BALL TEST}

In tests made by the falling ball method to determine the impact resistance of the plastics, it was found to be impractical to use the 12- by 12-inch frame employed for testing laminated safety glass, in which the specimen is not clamped at the edge. In such a frame a cellulose acetate sample, 94 mils thick, failed only on the 24th impact of a $1 / 2$ pound steel ball falling 65 feet. A nitrate specimen 65 mils thick pulled through the frame on the first impact. The following test procedure was, therefore, adopted. A steel ball weighing $1 / 2$ pound was dropped from various heights on a disk $6 \frac{1}{2}$ inches in diameter held firmly between rubber gaskets in a metal frame (fig. 18) which had a circular opening $5 \frac{1}{2}$ inches in diameter. The test was continued until the sample was penetrated by the ball. The results are given in table 16. The cellulose plastics failed when the ball dropped 50 to 65 feet, some requiring several impacts from the latter height. All of the acrylate resin samples failed when the ball was dropped 10 feet. The vinyl chloride-acetate resin samples failed at 8 feet, whereas a vinyl acetal resin now being developed particularly for safety-glass construction broke only after an average of $11 \frac{1}{2}$ impacts with the steel ball from 65 feet. 


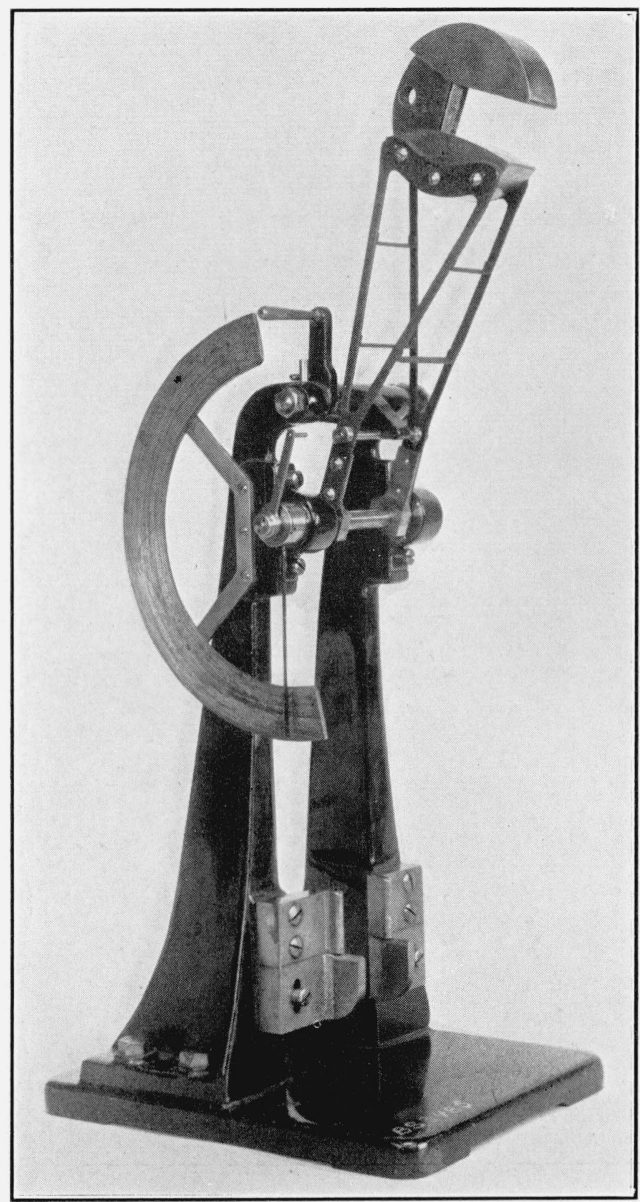

FigURE 17.-Apparatus for determining Charpy impact strength. 


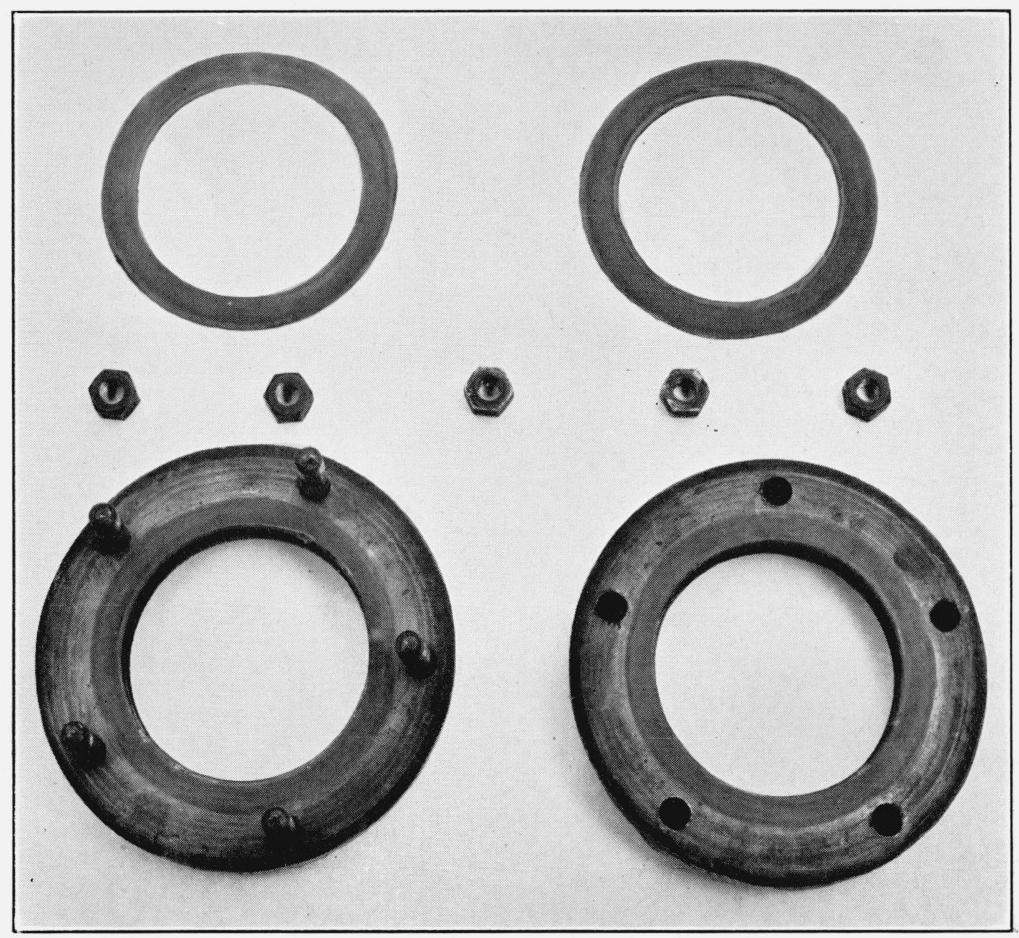

Figure 18.-Frame used to hold plastics in the falling-ball impact test. 
TABLE 16.-Charpy and dropped-ball impact tests on transparent plastics

\begin{tabular}{|c|c|c|c|c|c|c|}
\hline \multirow[b]{2}{*}{ Material } & \multirow[b]{2}{*}{$\begin{array}{c}\text { Sam- } \\
\text { plo }\end{array}$} & \multirow[b]{2}{*}{$\begin{array}{l}\text { Thick- } \\
\text { ness }\end{array}$} & \multicolumn{2}{|c|}{$\begin{array}{l}\text { Charpy impact } \\
\text { strength (notched) }\end{array}$} & \multicolumn{2}{|c|}{ Ball impact strength } \\
\hline & & & $70^{\circ} \mathrm{F}$ & $25^{\circ} \mathrm{F}$ & $\begin{array}{c}\text { Ball } \\
\text { height }\end{array}$ & $\begin{array}{c}\text { Average } \\
\text { number of } \\
\text { balls re- } \\
\text { quired for } \\
\text { failure }\end{array}$ \\
\hline 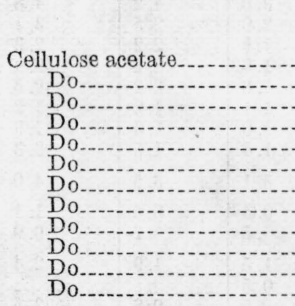 & $\begin{array}{l}A 1 \\
A 2 \\
A 3 \\
B 2 \\
B 4 \\
B 5 \\
B 6 \\
B 7 \\
B 9 \\
C 1 \\
C 3 \\
D 1\end{array}$ & $\begin{array}{r}\text { Mils } \\
65 \\
96 \\
135 \\
94 \\
98 \\
100 \\
67 \\
95 \\
92 \\
57 \\
125 \\
165\end{array}$ & $\begin{array}{r}\text { ft lb/in. } \\
\text { of notch } \\
2.8 \\
3.2 \\
2.1 \\
1.9 \\
3.0 \\
3.6 \\
2.7 \\
2.4 \\
2.3 \\
2.8 \\
2.4 \\
2.3\end{array}$ & $\begin{array}{r}\mathrm{ft} \mathrm{lb} / \mathrm{in} . \\
\text { of notch } \\
0.51 \\
.37 \\
.25 \\
.33 \\
1.51 \\
1.33 \\
0.89 \\
1.16 \\
0.29 \\
1.02 \\
0.84 \\
.30\end{array}$ & $\begin{array}{l}\mathrm{ft}^{6} \\
65 \\
50 \\
50 \\
65 \\
65 \\
65 \\
65 \\
65 \\
65 \\
65 \\
65 \\
50\end{array}$ & $\begin{array}{l}2.5 \\
7 \\
9 \\
6 \\
2.5 \\
10 \\
1 \\
6 \\
5 \\
3 \\
9 \\
6\end{array}$ \\
\hline $\begin{array}{l}\text { Cellulose nitrate } \\
\text { Do }\end{array}$ & $\begin{array}{l}E 1 \\
F 1\end{array}$ & $\begin{array}{l}66 \\
63\end{array}$ & $\begin{array}{l}3.8 \\
4.4\end{array}$ & $\begin{array}{l}2.13 \\
2.60\end{array}$ & $\begin{array}{l}65 \\
65\end{array}$ & $\begin{array}{l}4 \\
4.5\end{array}$ \\
\hline Ethylcellulose....... & G1 & 59 & 3.1 & 2. 49 & & \\
\hline $\begin{array}{l}\text { Acrylate resin } \\
\text { Do res. }\end{array}$ & $\begin{array}{l}K 1 \\
K 4 \\
K\end{array}$ & $\begin{array}{r}117 \\
88\end{array}$ & $\begin{array}{r}0.46 \\
.45\end{array}$ & $\begin{array}{r}0.33 \\
.26\end{array}$ & 3 & 2 \\
\hline Do.-- & $\begin{array}{l}K 7 \\
K 8\end{array}$ & $\begin{array}{l}222 \\
218\end{array}$ & $\begin{array}{l}.44 \\
.40\end{array}$ & $\begin{array}{l}.37 \\
.36\end{array}$ & $\begin{array}{l}10 \\
10\end{array}$ & $\begin{array}{l}2 \\
3\end{array}$ \\
\hline Vinyl chloride-acetate resin. & LS & 102 & .4 & .15 & 8 & 2 \\
\hline Vinyl acetal resin........ & $N i$ & 122 & 2.9 & .65 & 65 & 11.5 \\
\hline
\end{tabular}

In order to determine the effect of impacts of a comparatively inelastic body on the plastic, a tennis ball partially filled with 1 pound of shot was used in a series of tests. Results of tests on a few cellulose acetate samples indicate that a given sample will withstand three times as many impacts from this type of falling body as from a $1 / 2$-pound steel ball.

\section{SHRINKAGE}

The shrinkage which transparent plastics undergo in service is an important factor in their durability. Excessive shrinkage causes buckling and in some cases cracking of the plastic sheet.

The shrinkage of transparent plastics occurring during exposure on the roof and also as a result of accelerated aging was studied. Specimens approximately 11 by 1 inch were conditioned at $21^{\circ} \mathrm{C}$ and 65-percent relative humidity and gage lengths of 10 inches were marked off. One set of samples was placed on an exposure rack on the roof, while a second set was subjected to accelerated aging at $70^{\circ} \mathrm{C}$ in an oven in which the air was circulated. After various periods the samples were removed to the conditioning room for 24 hours and the change in length was measured. The results are presented in tables 17 and 18 . 
TABLE 17.-Accelerated shrinkage tests at $70^{\circ} \mathrm{C}$ of transparent plastics

\begin{tabular}{|c|c|c|c|c|c|c|}
\hline \multirow{2}{*}{ Material } & \multirow{2}{*}{ Sample } & \multirow{2}{*}{$\begin{array}{l}\text { Thick- } \\
\text { ness }\end{array}$} & \multicolumn{4}{|c|}{ Decrease in length } \\
\hline & & & 4 days & 2 weeks & 1 month & 2 months \\
\hline 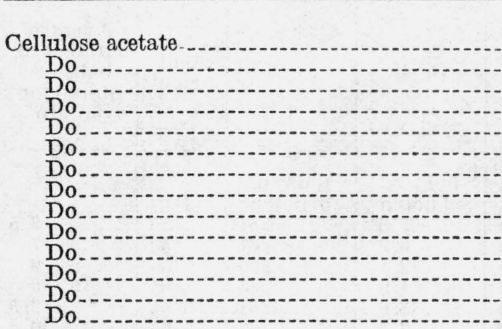 & $\begin{array}{l}A 3 \\
A 1 \\
A 2 \\
B 2 \\
B 3 \\
B 4 \\
B 5 \\
B 6 \\
B 9 \\
B 10 \\
B 11 \\
B 12 \\
C 3 \\
D 1\end{array}$ & \begin{tabular}{r|} 
Mils \\
133 \\
64 \\
95 \\
93 \\
64 \\
96 \\
100 \\
66 \\
89 \\
63 \\
64 \\
61 \\
125 \\
169
\end{tabular} & \begin{tabular}{|r|} 
Percent \\
0.9 \\
1.2 \\
1.0 \\
1.0 \\
$\mathrm{~s} 1.3$ \\
1.1 \\
2.0 \\
1.7 \\
1.4 \\
1.1 \\
1.0 \\
0.8 \\
.9 \\
1.1
\end{tabular} & $\begin{array}{r}\text { Percent } \\
1.0 \\
1.5 \\
1.1 \\
1.1 \\
2.1 \\
1.5 \\
3.5 \\
2.0 \\
1.8 \\
1.6 \\
1.6 \\
1.1 \\
1.0 \\
1.4\end{array}$ & $\begin{array}{r}\text { Percent } \\
1.3 \\
1.6 \\
1.5 \\
1.3 \\
1.8 \\
4.2 \\
2.5 \\
2.2 \\
2.2 \\
2.2 \\
1.2 \\
1.3 \\
1.5\end{array}$ & $\begin{array}{r}\text { Percent } \\
2.2 \\
3.4 \\
\text { (b) } \\
2.0 \\
1.7 \\
4.8 \\
3.1 \\
2.3 \\
2.4 \\
2.5 \\
1.2 \\
1.9 \\
2.3\end{array}$ \\
\hline Celluiose acetobutyrate & $S 1$ & 41 & 2.5 & 3.1 & 3.5 & 4. 0 \\
\hline $\begin{array}{l}\text { Cellulose nitrate- } \\
\text { Do }\end{array}$ & $\begin{array}{l}E 1 \\
F 1\end{array}$ & $\begin{array}{l}67 \\
64\end{array}$ & $\begin{array}{r}0.4 \\
.5\end{array}$ & $\begin{array}{r}0.4 \\
.5\end{array}$ & $\begin{array}{r}0.6 \\
.7\end{array}$ & $\begin{array}{l}1.1 \\
0.9\end{array}$ \\
\hline $\begin{array}{l}\text { Ethylcellulose } \\
\text { Do } \\
\text { Do }\end{array}$ & $\begin{array}{l}\text { G1 } \\
\stackrel{H}{H 1} \\
I 1\end{array}$ & $\begin{array}{l}53 \\
29 \\
38\end{array}$ & $\begin{array}{r}1.2 \\
0.4 \\
.5\end{array}$ & $\begin{array}{r}1.5 \\
0.5 \\
.6\end{array}$ & 1.9 & 2.4 \\
\hline 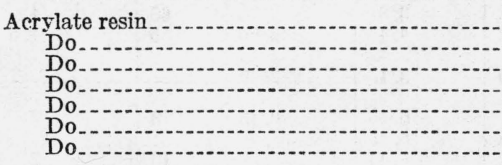 & $\begin{array}{l}J 1 \\
J 2 \\
K 1 \\
K 2 \\
K 3 \\
K 5 \\
K 9\end{array}$ & $\begin{array}{r}66 \\
76 \\
124 \\
88 \\
71 \\
118 \\
60\end{array}$ & $\begin{array}{r}2.2 \\
0.2 \\
2.0 \\
1.8 \\
1.5 \\
0.2 \\
\mathrm{a} 1.9\end{array}$ & $\begin{array}{l}\text { (b) } \\
0.2 \\
2.0 \\
1.8 \\
1.6 \\
0.3 \\
1.9\end{array}$ & $\begin{array}{l}\text { (b) } \\
0.2 \\
2.0 \\
1.8 \\
1.7 \\
0.3\end{array}$ & $\begin{array}{r}\text { (b) } \\
0.7 \\
2.0 \\
1.7 \\
-1 .\end{array}$ \\
\hline Vinyl chloride-acetate resin & $L 1$ & 64 & 4.2 & 4.3 & 4. 6 & 8. 2 \\
\hline $\begin{array}{l}\text { Vinyl acetal resin. } \\
\text { Doct }\end{array}$ & $\begin{array}{l}M 1 \\
N 1\end{array}$ & $\begin{array}{r}63 \\
127\end{array}$ & $\begin{array}{l}0.2 \\
0.4\end{array}$ & $\begin{array}{l}0.8 \\
0.6\end{array}$ & $\begin{array}{r}1.0 \\
.0 .6\end{array}$ & $\begin{array}{r}1.5 \\
00.9\end{array}$ \\
\hline $\begin{array}{l}\text { Glyceryl-phthalate resin } \\
\text { Do }\end{array}$ & $\begin{array}{l}O 1 \\
T 1\end{array}$ & $\begin{array}{l}162 \\
290\end{array}$ & .1 & .1 & .1 & $: 1$ \\
\hline Phenol-formaldehyde resin & $U 1$ & 170 & 1.0 & 1.4 & 1. 6 & 1.9 \\
\hline
\end{tabular}

A 3 days.

- Warped.

- Increase in length.

TABLE 18.-Outdoor shrinkage tests of transparent plastics

\begin{tabular}{|c|c|c|c|c|c|c|c|}
\hline \multirow[b]{2}{*}{ Material } & \multirow{2}{*}{$\begin{array}{l}\text { Sam- } \\
\text { ple }\end{array}$} & \multicolumn{6}{|c|}{ Decrease in length } \\
\hline & & $\begin{array}{c}1 \\
\text { month }\end{array}$ & $\stackrel{2}{\text { months }}$ & $\stackrel{3}{\text { months }}$ & $\stackrel{6}{\text { months }}$ & $\stackrel{9}{\text { months }}$ & $\begin{array}{c}1 \\
\text { year }\end{array}$ \\
\hline $\begin{array}{l}\text { Cellulose acetate } \\
\text { Do } \\
\text { Do } \\
\text { Do } \\
\text { Do } \\
\text { Do } \\
\text { Do }\end{array}$ & $\begin{array}{l}A 1 \\
A 2 \\
A 3 \\
B 2 \\
B 6 \\
C B \\
D 1\end{array}$ & $\begin{array}{c}\text { Percent } \\
1.3 \\
0.5 \\
.4 \\
.4 \\
.8 \\
.5 \\
.6\end{array}$ & $\begin{array}{r}\text { Percent } \\
1.8 \\
0.6 \\
.6 \\
.4 \\
1.2 \\
0.7 \\
.9\end{array}$ & $\begin{array}{r}\text { Percent } \\
2.5 \\
1.1 \\
0.9 \\
.6 \\
1.6 \\
1.1 \\
1.4\end{array}$ & $\begin{array}{l}\text { Percent } \\
2.7 \\
1.1 \\
1.0 \\
0.6 \\
1.8 \\
1.2 \\
1.4\end{array}$ & $\begin{array}{c}\text { Percent } \\
3.1 \\
1.4 \\
1.1 \\
0.7 \\
2.1 \\
1.3 \\
1.6\end{array}$ & $\begin{aligned} \text { Percent } \\
3.4 \\
1.3 \\
1.1 \\
0.8 \\
2.3 \\
1.3 \\
1.5\end{aligned}$ \\
\hline Cellulose acetobutyrate...... & $S 1$ & .5 & .7 & 0.9 & 1.0 & 1.0 & 1.1 \\
\hline $\begin{array}{l}\text { Cellulose nitrate } \\
\text { Do }\end{array}$ & $\begin{array}{l}E 1 \\
F 1\end{array}$ & $\begin{array}{l}.2 \\
.2\end{array}$ & $\begin{array}{l}.3 \\
.3\end{array}$ & $\begin{array}{l}.4 \\
.4\end{array}$ & $\begin{array}{r}0.4 \\
.4\end{array}$ & $\begin{array}{r}0.4 \\
.5\end{array}$ & $\begin{array}{r}0.5 \\
.6\end{array}$ \\
\hline $\begin{array}{l}\text { Ethylcellulose_- } \\
\text { Do } \\
\text { Do }\end{array}$ & $\begin{array}{l}G 1 \\
H 1 \\
I 1\end{array}$ & $\begin{array}{l}0.6 \\
1.0 \\
0.8\end{array}$ & $\begin{array}{l}1.1 \\
1.5 \\
1.1\end{array}$ & $\begin{array}{l}1.5 \\
2.0 \\
1.4\end{array}$ & $\begin{array}{l}\text { (a) } \\
\text { (a) } \\
1.8\end{array}$ & $\begin{array}{l}\text { (a) } \\
\text { (a) } \\
\text { (a) }\end{array}$ & $\begin{array}{l}(\mathrm{a}) \\
(\mathrm{a}) \\
(\mathrm{a})\end{array}$ \\
\hline $\begin{array}{l}\text { Acrylate resin } \\
\text { Do } \\
\text { Do } \\
\text { Do } \\
\text { Do } \\
\text { Do }\end{array}$ & $\begin{array}{l}J 1 \\
J 2 \\
K 1 \\
K 2 \\
K 6 \\
K 9\end{array}$ & $\begin{array}{l}.05 \\
.0 \\
.0 \\
.06 \\
.0 \\
.04\end{array}$ & $\begin{array}{r}0.1 \\
.0 \\
.2 \\
.1\end{array}$ & $\begin{array}{r}0.1 \\
.0 \\
.2 \\
.0 \\
.2\end{array}$ & $\begin{array}{l}0.1 \\
.0 \\
.2 \\
.1 \\
.05 \\
.2\end{array}$ & $\begin{array}{l}.1 \\
.0 \\
.2 \\
.1 \\
.06 \\
.2\end{array}$ & $\begin{array}{r}.1 \\
.0 \\
.2 \\
.1 \\
.2\end{array}$ \\
\hline Vinyl chloride-acetate resin & $L 1$ & .0 & .0 & .0 & .0 & .03 & .03 \\
\hline Vinyl acetal resin & N1 & .4 & (a) & (a) & (s) & (a) & (s) \\
\hline $\begin{array}{l}\text { Glyceryl-phthalate resin } \\
\text { Do }\end{array}$ & $\begin{array}{l}01 \\
T 1\end{array}$ & .0 & 0 & .0 & $\begin{array}{r}\text { b. } 1 \\
.1\end{array}$ & $\begin{array}{r}\text { b. } 1 \\
.1\end{array}$ & $\begin{array}{r}\text { b. } 1 \\
.1\end{array}$ \\
\hline Phenol-formaldehyde resin & U1 & .8 & 1.0 & 1. 2 & 1.4 & 1.5 & 1.5 \\
\hline
\end{tabular}


When the shrinkage is accelerated by heating at $70^{\circ} \mathrm{C}$, the decrease in length after 4 days is very nearly the same for many of the materials as that observed after 2 weeks in the oven. For cellulose acetate plastics, the shrinkage after 2 weeks was about 1 percent for 120-mil stock and 2 percent for the 60-mil material; after 2 months these values had increased to approximately 2 and 3 percent, respectively. The lowest shrinkage of all the cellulose acetate samples was undergone by sample B12, a 60-mil sheet, the change in length being 1.2 percent in 2 months. The two cellulose nitrate samples had decreased 0.5 percent in length in 2 weeks and 1 percent in 2 months. The acrylate resin plastics, which were first submitted, shrunk almost 2 percent in 2 weeks at $70^{\circ} \mathrm{C}$ and did not change appreciably thereafter. A later sample of this type of resin, identified as $K 5$, which was given a final heat treatment by the manufacturer, shrunk approximately 0.3 percent in 2 weeks, after which no further change in the length was observed. A sample of unplasticized acrylate resin, J2, decreased in length only 0.2 percent in 2 weeks, but showed 0.7 percent shrinkage after 2 months. The greatest shrinkage during the 2 months of heating at $70^{\circ} \mathrm{C}$ occurred with a vinyl chloride-acetate resin; the decrease in length being 8.2 percent. A glyceryl-phthalate resin, 01 , underwent the least shrinkage, namely, 0.1 percent; another sample of this resin, made by a different company, decreased 0.7 percent in length.

The degree of shrinkage of materials during outdoor exposure was somewhat different than under accelerated aging. In general, the outdoor shrinkage of the synthetic resins was small compared to that of the cellulose plastics. Reasonably good correlation was observed between the shrinkages for the various cellulose derivatives exposed on the roof and heated at $70^{\circ} \mathrm{C}$ in the oven. The cellulose acetate samples decreased in length from 0.8 to 3.4 percent in 1 year on the roof, whereas the same samples decreased 2.0 to 3.4 percent when heated for 2 months at $70^{\circ} \mathrm{C}$. The cellulose nitrate samples averaged 0.55 -percent shrinkage for 1 year on the roof and 1 percent for 2 months' heating at $70^{\circ} \mathrm{C}$. 'The ethylcellulose plastics deteriorated rapidly on the roof, making measurements impossible after approximately 6 months. They had shrunk 2.0 percent at the end of 3 months on the roof compared with an average value of about 3 percent for the accelerated test. The acrylate resins had decreased in length only about 0.2 percent in 1 year on the roof; the heat-treated resin shrunk approximately 0.05 percent in 6 months. The greatest disparity between the natural and accelerated aging was noted in the case of the vinyl chloride-acetate resin, which, although it shrunk 8.2 percent in 2 months at $70^{\circ} \mathrm{C}$, had decreased in length less than 0.05 percent after 1 year on the roof.

Presumably it would be possible to reduce the shrinkage of the cellulose plastics by heat treatment during the process of manufacture as was done for the acrylate resin sample $K 5$. The impact strength of sample $K 5$ as measured on the Charpy apparatus was the same as that of the ordinary acrylate stock. As indicated in tables 12 and 15, the values of scratch resistance and indentation hardness are higher for the preshrunk than for the ordinary acrylate. Samples of ordinary cellulose acetate and cellulose nitrate were preshrunk by heating at $100^{\circ} \mathrm{C}$ for 4 - and 24 -hour periods. Impact measurements were made 
at $21^{\circ} \mathrm{C}$ with the Charpy apparatus on both the untreated and heated materials. The decrease in length was also determined; the specimens used to measure shrinkage were placed on the roof to detect further shrinkage. The results are given in table 19. The impact strength of the cellulose acetate sample was decreased only 5 percent by heating for 4 hours; the same treatment halved the impact strength of the nitrate and caused it to discolor. It would seem, therefore that a method of heat treatment which would remove residual volatile solvent, the gradual loss of which may be in large part responsible for the shrinkage of the cellulose acetate plastics, would yield a much improved material for windshields.

TABLE 19.-Effect of heating cellulosic plastics at $100^{\circ} \mathrm{C}$ on impact sirength and shrinkage

\begin{tabular}{|c|c|c|c|c|c|c|c|}
\hline \multirow{2}{*}{ Material } & \multirow{2}{*}{ Sample } & \multirow{2}{*}{$\begin{array}{l}\text { Thick- } \\
\text { ness }\end{array}$} & \multicolumn{3}{|c|}{$\begin{array}{l}\text { Charpy impact strength on } \\
\text { notched specimen }\end{array}$} & \multicolumn{2}{|c|}{ Shrinkage } \\
\hline & & & Original & $\begin{array}{c}\text { After } 4 \\
\text { hours at } \\
100^{\circ} \mathrm{C}\end{array}$ & $\begin{array}{c}\text { After } 24 \\
\text { hours at } \\
100^{\circ} \mathrm{C}\end{array}$ & $\begin{array}{c}\text { After } 4 \\
\text { hours at } \\
100^{\circ} \mathrm{C}\end{array}$ & $\begin{array}{c}\text { After } 24 \\
\text { hours at } \\
100^{\circ} \mathrm{C}\end{array}$ \\
\hline $\begin{array}{l}\text { Cellulose acetate } \\
\text { Cellulose nitrate }\end{array}$ & $\begin{array}{r}C 5 \\
W 1\end{array}$ & $\begin{array}{r}\text { Mils } \\
92 \\
93\end{array}$ & $\begin{array}{r}\mathrm{ft} \mathrm{lb} / \mathrm{in} . \\
\text { of notch } \\
1.9 \\
3.6\end{array}$ & $\begin{array}{r}\mathrm{ft} \mathrm{lb/in.} \\
\text { of notch } \\
1.8 \\
1.8\end{array}$ & $\begin{array}{r}\mathrm{ft} \mathrm{lb/in.} \\
\text { of noteh } \\
1.4 \\
1.8\end{array}$ & $\begin{array}{r}\text { Percent } \\
2.0 \\
1.6\end{array}$ & $\begin{array}{r}\text { Percent } \\
3.3 \\
2.0\end{array}$ \\
\hline
\end{tabular}

\section{RESISTANCE TO WATER, ALCOHOL, AND KEROSENE}

Resistance to water and to various organic solvents with which it is likely to come in contact is an important property of a transparent plastic which is to be used as an airplane windshield. Data were, therefore, obtained as to the amount of water, alcohol, and kerosene absorbed by the various plastics when immersed in these liquids and also as to their effect on the condition of the surface and appearance of the samples. The results of these tests are presented in tables 20 to 22 . It will be noted in table 20 that the absorption of water is particularly pronounced in the case of the cellulosic plastics, with the exception of cellulose acetobutyrate. Two of the three ethylcellulose samples became cloudy when exposed to water for 48 hours. This behavior would be very objectionable in a material for windshields. The resinous materials absorb very little moisture, with the exception of the vinyl acetal sample, $M 1$, a vinyl acetate polymer which has been hydrolyzed and condensed with formaldehyde. This resin also becomes cloudy when wet and warps badly. The acrylate and vinyl resins are not affected by water.

As shown by the data in table 21, alcohol has a decidedly detrimental effect on all the transparent plastics studied, with the exception of the vinyl chloride-acetate resin and, therefore, should not be used for cleaning windshields. 
TABLE 20.-Water absorption by transparent plastics at $70^{\circ} \mathrm{F}$

\begin{tabular}{|c|c|c|c|c|c|c|}
\hline \multirow{2}{*}{ Material } & \multirow{2}{*}{ Sample } & \multirow{2}{*}{$\begin{array}{l}\text { Thick- } \\
\text { ness }\end{array}$} & \multicolumn{3}{|c|}{ Gain in weight } & \multirow{2}{*}{ Remarks } \\
\hline & & & $\begin{array}{l}\text { After } 2 \\
\text { hr }\end{array}$ & $\begin{array}{l}\text { After } 24 \\
\text { hr }\end{array}$ & $\begin{array}{l}\text { After } 7 \\
\text { days }\end{array}$ & \\
\hline $\begin{array}{l}\text { Cellulose acetate } \\
\text { Do } \\
\text { Do } \\
\text { Do } \\
\text { Do } \\
\text { Do }\end{array}$ & $\begin{array}{l}A 1 \\
B 1 \\
B 3 \\
C 1 \\
C 3 \\
D 1\end{array}$ & $\begin{array}{r}\text { Mils } \\
66 \\
64 \\
62 \\
58 \\
126 \\
165\end{array}$ & $\begin{array}{r}\text { Percent } \\
0.63 \\
.59 \\
.52 \\
.68 \\
.38\end{array}$ & $\begin{array}{r}\text { Percent } \\
2.39 \\
2.02 \\
1.82 \\
2.10 \\
1.32 \\
\end{array}$ & $\begin{array}{r}\text { Percent } \\
3.25 \\
2.40 \\
2.19 \\
2.08 \\
3.34\end{array}$ & \\
\hline $\begin{array}{l}\text { Cellulose nitrate. } \\
\text { Do }\end{array}$ & $\begin{array}{l}E 1 \\
F 1\end{array}$ & $\begin{array}{l}66 \\
63\end{array}$ & $\begin{array}{l}.19 \\
.25\end{array}$ & $\begin{array}{r}0.73 \\
.88\end{array}$ & $\begin{array}{l}\text { 1. } 23 \\
1.33\end{array}$ & \\
\hline Cellulose acetobutyrate. & S1 & 36 & .43 & .85 & 0.76 & \\
\hline $\begin{array}{l}\text { Ethylcellulose } \\
\text { Do } \\
\text { Do }\end{array}$ & $\begin{array}{l}\text { G1 } \\
H 1 \\
I 1\end{array}$ & $\begin{array}{l}58 \\
29 \\
35\end{array}$ & $\begin{array}{l}.56 \\
3.25 \\
2.50\end{array}$ & $\begin{array}{l}\text { 1. } 91 \\
8.71 \\
3.21\end{array}$ & $\begin{array}{l}2.91 \\
9.32 \\
3.61\end{array}$ & $\begin{array}{l}\text { Cloudy at } 48 \mathrm{hr} \text {. } \\
\text { Slightly cloudy at } 48 \mathrm{hr} \text {. }\end{array}$ \\
\hline $\begin{array}{l}\text { Acrylate resin } \\
\text { Do } \\
\text { Do } \\
\text { Do........ }\end{array}$ & $\begin{array}{l}J 1 \\
J 2 \\
K 1 \\
K 2\end{array}$ & $\begin{array}{r}79 \\
70 \\
116 \\
88\end{array}$ & $\begin{array}{l}0.05 \\
.06 \\
.04 \\
.07\end{array}$ & $\begin{array}{l}0.21 \\
.29 \\
.14 \\
.27\end{array}$ & $\begin{array}{r}0.51 \\
.79 \\
.43 \\
.40\end{array}$ & \\
\hline $\begin{array}{l}\text { Vinyl chloride-acetate } \\
\text { resin. } \\
\text { Do }\end{array}$ & $\begin{array}{l}L 1 \\
L 2\end{array}$ & 100 & $\begin{array}{l}.02 \\
.01\end{array}$ & $\begin{array}{l}.05 \\
.03\end{array}$ & $\begin{array}{l}.07 \\
.04\end{array}$ & \\
\hline Vinyl acetal resin & M1 & 61 & .59 & 2.45 & 5. 70 & Cloudy after $2 \mathrm{hr}$. \\
\hline
\end{tabular}

TABLE 21.-Absorption of ethyl alcohol $(95 \%)$ by transparent plastics at $70^{\circ} \mathrm{F}$

\begin{tabular}{|c|c|c|c|c|c|}
\hline \multirow{2}{*}{ Material } & \multirow{2}{*}{ Sample } & \multicolumn{3}{|c|}{ Gain in weight } & \multirow{2}{*}{ Remarks } \\
\hline & & $\begin{array}{l}\text { After } 2 \\
\mathrm{hr}\end{array}$ & $\begin{array}{l}\text { After } 24 \\
\text { hr }\end{array}$ & $\begin{array}{l}\text { Afte } 7 \\
\text { days }\end{array}$ & \\
\hline 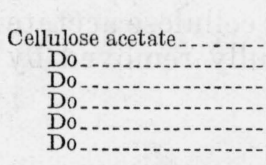 & $\begin{array}{l}A 1 \\
B 1 \\
B 3 \\
C 1 \\
C B \\
D 1\end{array}$ & $\begin{array}{r}\text { Percent } \\
4.08 \\
2.41 \\
2.95 \\
3.13 \\
1.49 \\
1.52\end{array}$ & $\begin{array}{r}\text { Percent } \\
15.72 \\
10.72 \\
12.57 \\
11.14 \\
6.58 \\
6.84\end{array}$ & $\begin{array}{r}\text { Percent } \\
10.68 \\
6.64 \\
7.34 \\
4.85 \\
7.91 \\
14.99\end{array}$ & $\begin{array}{l}\text { Surface rippled; slightly cloudy. } \\
\text { Do. } \\
\text { Do. } \\
\text { Do. } \\
\text { Do. } \\
\text { Quite cloudy. }\end{array}$ \\
\hline Cellulose nitrate & E1 & 3. 21 & 36.5 & & $\begin{array}{l}\text { Surface roughened in } 2 \mathrm{hr} \text {; swollen } \\
\text { after } 1 \text { week. }\end{array}$ \\
\hline Do & $F 1$ & 4. 98 & & & $\begin{array}{l}\text { Surface roughened in } 2 \mathrm{hr} \text {; swollen } \\
\text { after } 24 \mathrm{hr} \text {. }\end{array}$ \\
\hline Celluiose acetobutyrate_- & $S 1$ & 6. 43 & 6. 02 & 3. 79 & No effect on appearance. \\
\hline $\begin{array}{l}\text { Ethylcellulose............... } \\
\text { Do }\end{array}$ & $\begin{array}{l}G 1 \\
H 1 \\
I 1\end{array}$ & & , & (n) & $\begin{array}{l}\text { Dissolves. } \\
\text { Do. } \\
\text { Do. }\end{array}$ \\
\hline $\begin{array}{l}\text { Acrylate resin } \\
\text { Do } \\
\text { Do } \\
\text { Do }\end{array}$ & $\begin{array}{l}J 1 \\
J 2 \\
K 1 \\
K 2\end{array}$ & $\begin{array}{r}0.22 \\
-.02 \\
.00 \\
10.15\end{array}$ & $\begin{array}{r}8.51 \\
9.67 \\
3.23 \\
86.90\end{array}$ & $\begin{array}{r}16.49 \\
9.65 \\
20.92\end{array}$ & $\begin{array}{l}\text { Surface pitted. } \\
\text { Surface roughened. } \\
\text { Surface roughened after } 2 \mathrm{hr} \text {; smooth at } \\
1 \text { week. } \\
\text { Softened in } 2 \mathrm{hr} \text {; swollen after } 1 \text { week. }\end{array}$ \\
\hline $\begin{array}{l}\text { Vinyl chloride-acetate } \\
\text { resin. } \\
\text { Do }\end{array}$ & $\begin{array}{l}L 1 \\
L \mathscr{2}\end{array}$ & $\begin{array}{r}-0.01 \\
-.01\end{array}$ & $\begin{array}{r}-0.03 \\
-.01\end{array}$ & $\begin{array}{r}0.00 \\
.04\end{array}$ & $\begin{array}{l}\text { No attack. } \\
\text { Do. }\end{array}$ \\
\hline Vinyl acetal resin ......... & M1 & 5. 70 & 18.16 & 11. 79 & Milk-white and opaque at 1 week. \\
\hline
\end{tabular}


TABLE 22.-Kerosene absorption by transparent plastics at $70^{\circ} \mathrm{F}$

\begin{tabular}{|c|c|c|c|c|}
\hline \multirow[b]{2}{*}{ Material } & \multirow[b]{2}{*}{ Sample } & \multicolumn{3}{|c|}{ Gain in weight } \\
\hline & & After $2 \mathrm{hr}$ & After $24 \mathrm{hr}$ & $\begin{array}{l}\text { After } 7 \\
\text { days }\end{array}$ \\
\hline 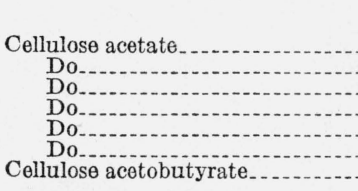 & $\begin{array}{l}A 1 \\
B 1 \\
B 3 \\
C 1 \\
C B \\
D 1 \\
S 1\end{array}$ & $\begin{array}{r}\text { Percent } \\
-0.12 \\
.01 \\
-.06 \\
-.14 \\
-.08 \\
=.04 \\
-.14\end{array}$ & $\begin{array}{r}\text { Percent } \\
-0.22 \\
-.03 \\
=.10 \\
=.31 \\
=.17 \\
=.11 \\
-.22\end{array}$ & $\begin{array}{r}\text { Percent } \\
-0.38 \\
-.14 \\
=.22 \\
=.59 \\
=.36 \\
=.23 \\
-.44\end{array}$ \\
\hline $\begin{array}{l}\text { Cellulose nitrate } \\
\text { Do }\end{array}$ & $\begin{array}{l}E 1 \\
F 1\end{array}$ & $\begin{array}{r}.00 \\
-.01\end{array}$ & $\begin{array}{r}-.03 \\
.00\end{array}$ & $\begin{array}{l}-.06 \\
-.04\end{array}$ \\
\hline $\begin{array}{l}\text { Acrylate resin } \\
\text { Do-o- } \\
\text { Do-a. } \\
\text { Do }\end{array}$ & $\begin{array}{l}J 1 \\
J 2 \\
K 1 \\
K 2\end{array}$ & $\begin{array}{r}.00 \\
-.01 \\
-.02\end{array}$ & $\begin{array}{r}-.01 \\
-.01 \\
-.04 \\
.01\end{array}$ & $\begin{array}{l}-.05 \\
-.09 \\
-.09 \\
.01\end{array}$ \\
\hline $\begin{array}{l}\text { Vinyl chloride-acetate resin } \\
\text { Do }\end{array}$ & $\begin{array}{l}L 1 \\
L 2\end{array}$ & $\begin{array}{r}.00 \\
-.03\end{array}$ & $\begin{array}{r}.02 \\
-.04\end{array}$ & $=.02$ \\
\hline 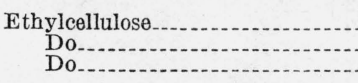 & $\begin{array}{l}G 1 \\
H 1 \\
I 1\end{array}$ & $\begin{array}{r}.09 \\
.42 \\
3.82\end{array}$ & $\begin{array}{r}.67 \\
1.82 \\
15.24\end{array}$ & $\begin{array}{r}2.00 \\
5.04 \\
20.12\end{array}$ \\
\hline Vinyl acetal resin ...... & M1 & 0.00 & -0.03 & -0.08 \\
\hline
\end{tabular}

The absorption of kerosene by all the plastics except ethylcellulose was negligible according to the results shown in table 22. The three samples of ethylcellulose differed markedly in their affinity for kerosene. However, no impairment of transparency or roughening of the surface on any of these samples was noted. Kerosene is, therefore, a very suitable reagent for cleaning the surfaces of plastic windshields. It was found to be very effective in removing, before proceeding with measurements of light transmission and haziness, a frosty-appearing layer which accumulated on the surface of some of the cellulose acetate samples used in exposure tests and which was not fully removed by washing with water.

\section{BURSTING STRENGTH}

Tests of bursting strength were made on a few specimens of cellulose acetate, cellulose nitrate, and acrylate resin. Circular disks 7 inches in diameter of the various materials were cut out and conditioned at $21^{\circ} \mathrm{C}$ and 65 -percent relative humidity. In the testing apparatus the specimen was held between steel clamping rings having an opening 5 inches in diameter. Hydraulic pressure from a hand pump was applied to one side of the disk and was increased until the disk was ruptured. The pressure to produce rupture was taken as a measure of the bursting strength. These tests were repeated with the specimen protected from the steel rings by rubber gaskets $1 / 16$ inch thick.

All specimens except the acrylate resins were greatly deformed by the test, and assumed a dome-like appearance. The results are presented in table 23 . 


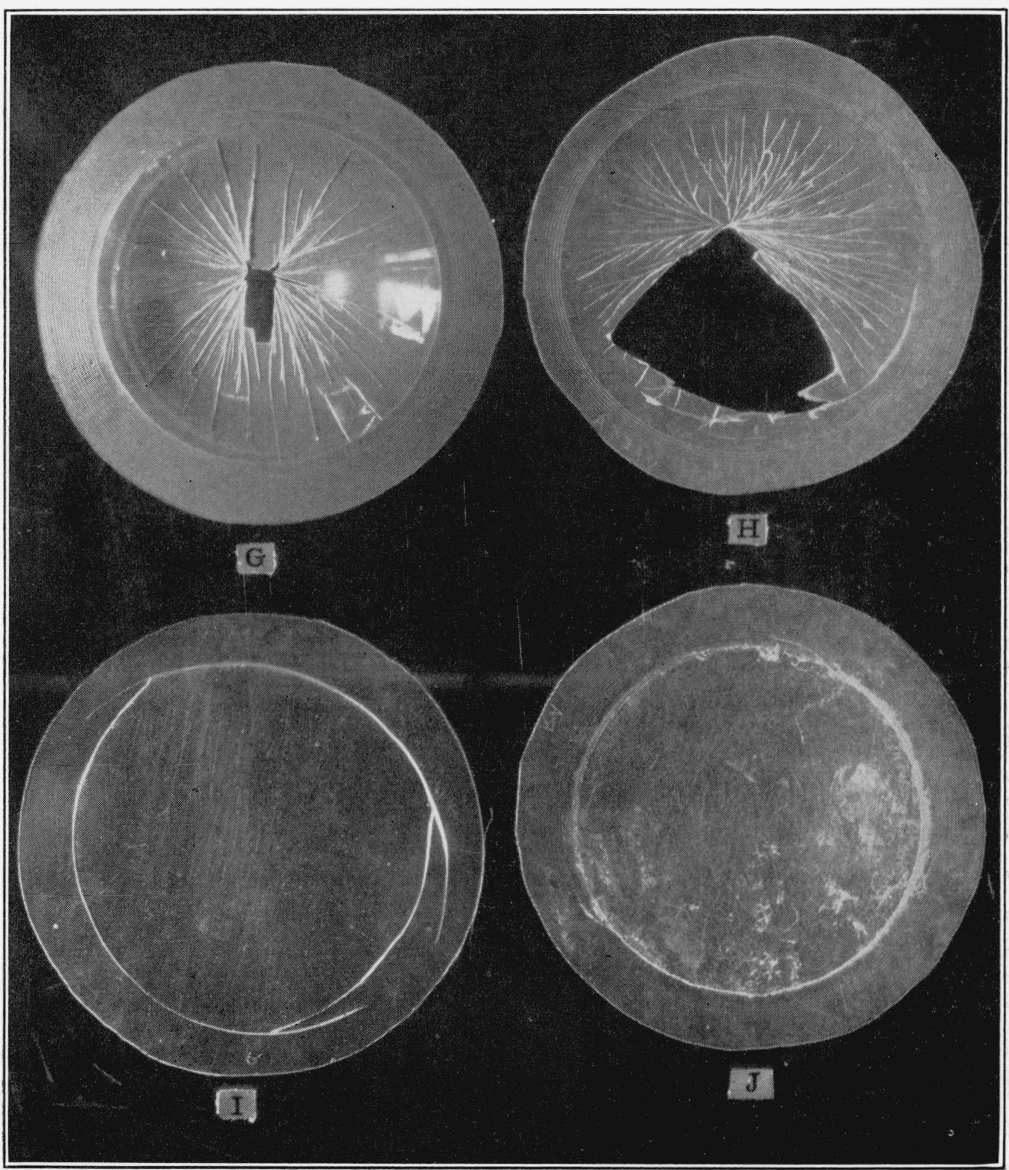

FIGURE 19.-Samples of transparent plastics after bursting strength tests.

$G$. Cellulose acetate burst at about $25^{\circ} \mathrm{C}$.

II. Cellulose acetate burst when one surface was cooled with ethylene dichloride at $-35^{\circ} \mathrm{C}$.

I. Acrylate resin burst at about $25^{\circ} \mathrm{C}$.

$\dot{J}$. Acrylate resin burst when one surface was cooled with ethylene dichloride at $-35^{\circ} \mathrm{C}$. 


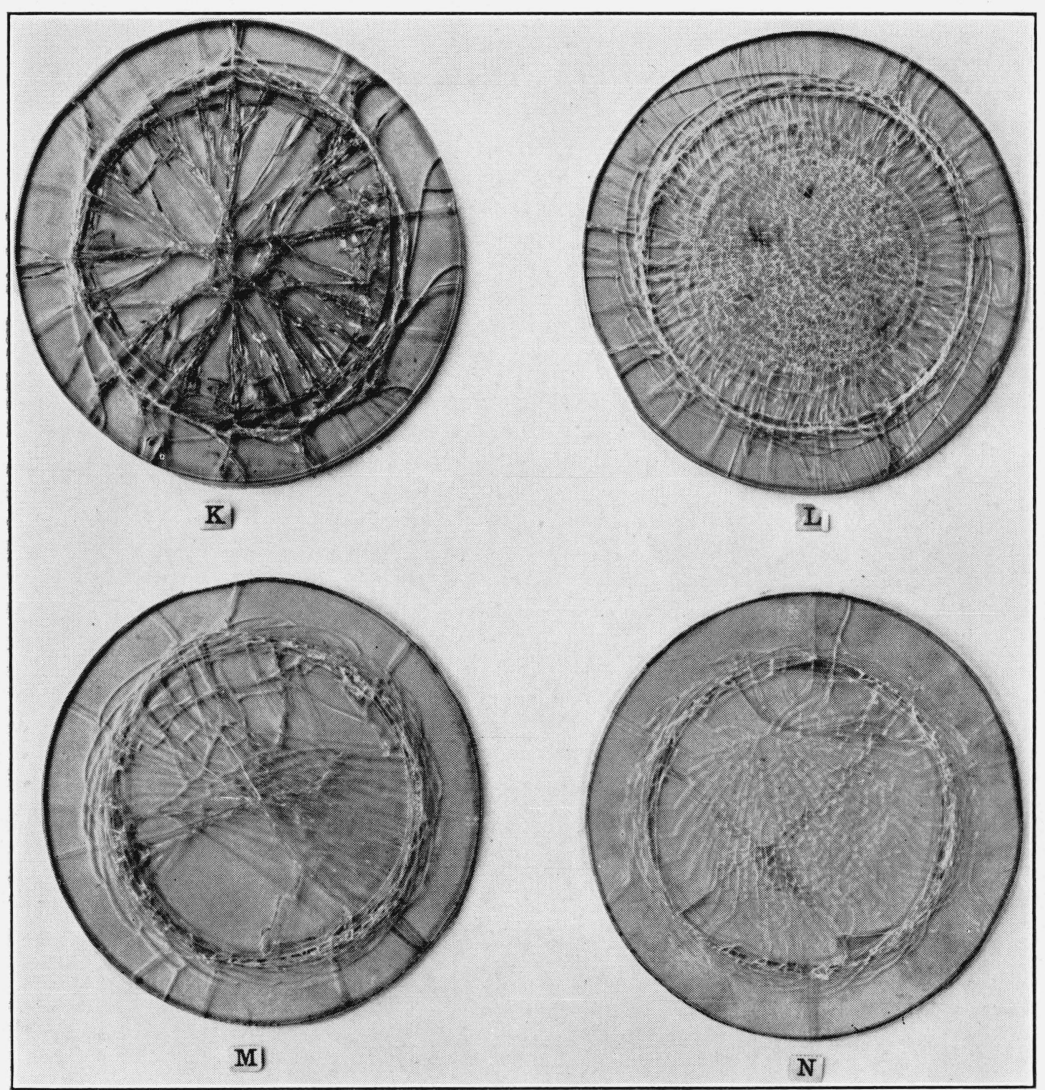

Figure 20.-Samples of laminated glass after bursting strength tests.

$K$. Glass bonded with cellulose nitrate plastic.

$L$. Glass bonded with cellulose acetate plastic.

$M$. Glass bonded with vinyl resin plastic.

$N$. Glass bonded with acrylate resin plastic. 
TABLE 23.-Bursting tests on 5-inch disles of transparent plastics at approximately $25^{\circ} \mathrm{C}$

A. WITHOUT RUBBER GASKETS

\begin{tabular}{|c|c|c|c|c|}
\hline Material & Sample & $\begin{array}{l}\text { Thick- } \\
\text { ness }\end{array}$ & $\begin{array}{l}\text { Bursting } \\
\text { strength }\end{array}$ & Location of failure \\
\hline $\begin{array}{r}\text { Cellulose acetate. } \\
\text { Do } \\
\text { Do } \\
\text { Do }\end{array}$ & $\begin{array}{l}B 2 \\
B 3 \\
C 1 \\
C S\end{array}$ & $\begin{array}{r}\text { Mils } \\
93 \\
65 \\
57 \\
125\end{array}$ & $\begin{array}{r}\text { lb/in. }{ }^{2} \\
295 \\
200 \\
165 \\
400\end{array}$ & $\begin{array}{l}\text { At clamping rings. } \\
\text { In center. } \\
\text { At clamping rings. } \\
\text { In center. }\end{array}$ \\
\hline Cellulose nitrate...... & $W 1$ & 93 & 375 & At clamping rings. \\
\hline Acrylate resin & $\begin{array}{l}K 5 \\
K 10\end{array}$ & $\begin{array}{l}70 \\
98\end{array}$ & $\begin{array}{l}26 \\
46\end{array}$ & $\begin{array}{l}\text { Do. } \\
\text { Do. }\end{array}$ \\
\hline Vinyl acetal resin... & N1 & 49 & 100 & Pinhole developed between \\
\hline Do..... & N1 & 49 & 115 & At clamping rings. \\
\hline
\end{tabular}

B. WITH RUBBER GASKETS

\begin{tabular}{|c|c|c|c|c|c|}
\hline Cellulose acetate. & $B 2$ & 93 & & 340 & At clamping rings (slipped \\
\hline Do & $C 1$ & $\begin{array}{r}56 \\
125\end{array}$ & & 190 & In center. \\
\hline Cellulose nitrate........... & $W 1$ & 93 & - & 380 & Do. \\
\hline $\begin{array}{l}\text { Acrylate resin } \\
\text { Do.. } \\
\text { Do. } \\
\text { Do } \\
\text { Do } \\
\text { Do } \\
\text { Do }\end{array}$ & $\begin{array}{l}K 10 \\
K 11 \\
K 11 \\
K 12 \\
K 12 \\
K 13 \\
K 13\end{array}$ & $\begin{array}{r}97 \\
65 \\
73 \\
97 \\
98 \\
202 \\
185\end{array}$ & & $\begin{array}{r}44 \\
33 \\
32 \\
45 \\
45 \\
117 \\
100\end{array}$ & $\begin{array}{l}\text { Between clamping rings. } \\
\text { At clamping rings. } \\
\text { Do. } \\
\text { Do. } \\
\text { Do. } \\
\text { Do. } \\
\text { Do. }\end{array}$ \\
\hline
\end{tabular}

Figure 19 shows samples of cellulose acetate, $G$, and acrylate resin, $I$, after the bursting-strength determination. Without rubber gaskets most of the samples failed at the clamping rings. However, when protected by the rubber gaskets, only the acrylate resin and one cellulose acetate sample failed in this location. The other specimens failed in the center along radial lines. The gaskets had very little effect on the numercial value obtained for bursting strength.

The effect on the bursting strength of cooling one surface of the plastic to approximately $-35^{\circ} \mathrm{C}$ was also determined. The cooling was accomplished by application of a mixture of solid carbon dioxide and an organic liquid to the outer surface and allowing the mixture to remain in contact with the plastic for 5 minutes before forcing water at room temperature against the opposite surface. The results of these tests are presented in table 24.

When kerosene or ethylene glycol was used as the cooling medium, the bursting strengths of the cellulose acetate and acrylate plastics were about the same as the values obtained at room temperature. Ethylene dichloride at $-35^{\circ} \mathrm{C}$ had a deleterious effect on both cellulose acetate and acrylate resin and caused the bursting strengths to be much lower than were observed with kerosene and ethylene glycol. 
Thus, one sample of an acrylate type of resin 0.2 inch thick failed at 100 to $117 \mathrm{lb} /$ in. $^{2}$ at room temperature, at 108 to $126 \mathrm{lb} / \mathrm{in}^{2}{ }^{2}$ at $-35^{\circ} \mathrm{C}$ when cooled with the kerosene-carbon dioxide mixture, and at 64 $\mathrm{lb} / \mathrm{in}^{2}{ }^{2}$ when ethylene dichloride was used as the cooling medium. Examination of the latter specimen revealed minute crazing of the cooled surface. Likewise, cellulose acetate approximately 0.1 inch thick, which failed at $350 \mathrm{lb} / \mathrm{in}^{2}{ }^{2}$ with the kerosene-carbon dioxide mixture, burst at $167 \mathrm{lb} / \mathrm{in}^{2}{ }^{2}$ when tested under similar conditions, except that ethylene dichloride was used in cooling the specimen. It is concluded that the spontaneous cracking of cellulose acetate windshields reported to occur on planes which have ascended to high altitudes, is due to loss in strength of the particular product because of poor aging characteristics rather than because of inherent weakness of the original cellulose acetate sheet.

TABLE 24.-Bursting tests on 5-inch disks of transparent plastics cooled to approximately $-35^{\circ} \mathrm{C}$ on outer surface

\section{A. WITHOUT RUBBER GASKETS}

\begin{tabular}{|c|c|c|c|c|c|}
\hline Material & Sample & $\begin{array}{l}\text { Thick- } \\
\text { ness }\end{array}$ & $\begin{array}{l}\text { Cooling liquid applied on } \\
\text { top surface }\end{array}$ & $\begin{array}{l}\text { Burst- } \\
\text { ing } \\
\text { strength }\end{array}$ & Location of failure \\
\hline $\begin{array}{l}\text { Cellulose acetate } \\
\text { Do } \\
\text { Do } \\
\text { Do... }\end{array}$ & $\begin{array}{l}B 14 \\
B 14 \\
C 6 \\
C 6\end{array}$ & $\begin{array}{r}\text { Mils } \\
107 \\
107 \\
127 \\
127\end{array}$ & $\begin{array}{l}\text { Ethylene dichloride. } \\
\text { Kerosene }\end{array}$ & $\begin{array}{r}\text { lb/in. }{ }^{2} \\
167 \\
350 \\
370 \\
420\end{array}$ & $\begin{array}{l}\text { In center. } \\
\text { In center and at rings. } \\
\text { In center. } \\
\text { In center and at rings. }\end{array}$ \\
\hline $\begin{array}{l}\text { Acrylate resin } \\
\text { Do }\end{array}$ & $\begin{array}{l}K 5 \\
K 11\end{array}$ & $\begin{array}{l}73 \\
65\end{array}$ & $\begin{array}{l}\text { Ethylene dichloride..... } \\
\text { Kerosene....... }\end{array}$ & $\begin{array}{l}\text { (a) } \\
33\end{array}$ & $\begin{array}{l}\text { At clamping rings; sur- } \\
\text { face crazed. } \\
\text { At clamping rings. }\end{array}$ \\
\hline
\end{tabular}

B. WITH RUBBER GASKETS

\begin{tabular}{|c|c|c|c|c|c|}
\hline Cellulose acetate & $B 14$ & 107 & Ethylene dichloride....... & 180 & At clamping rings. \\
\hline $\begin{array}{l}\text { Acrylate resin } \\
\text { Do } \\
\text { Do } \\
\text { Do } \\
\text { Do } \\
\text { Do } \\
\text { Do }\end{array}$ & $\begin{array}{l}K \gamma \\
K \gamma \\
K 12 \\
K 12 \\
K 13 \\
K 13 \\
K 13\end{array}$ & $\begin{array}{r}231 \\
232 \\
97 \\
97 \\
199 \\
201 \\
192\end{array}$ & $\begin{array}{l}\text { Kerosene } \\
\text { Ethylene glycol } \\
\text { Kerosene }\end{array}$ & $\begin{array}{r}168 \\
142 \\
51 \\
58 \\
126 \\
108 \\
64\end{array}$ & $\begin{array}{l}\text { Do. } \\
\text { Do. } \\
\text { Do. } \\
\text { Do. } \\
\text { Do. } \\
\text { Do. } \\
\text { In center and at clamp- } \\
\text { ing rings; surface } \\
\text { crazed. }\end{array}$ \\
\hline
\end{tabular}

- Failed before appreciable load could be applied.

A few samples of laminated glass and plate glass were tested at $25^{\circ} \mathrm{C}$ in the same bursting-strength apparatus used for the plastic sheets. The results of these tests are presented in table 25, and the condition of the laminated-glass products after test is shown in figure 20 . It will be noted that the bursting strengths of these materials are considerably less than those observed for the cellulose acetate plastic sheets. 
TABLE 25.-Bursting tests on 5-inch disks of laminated and plate glass

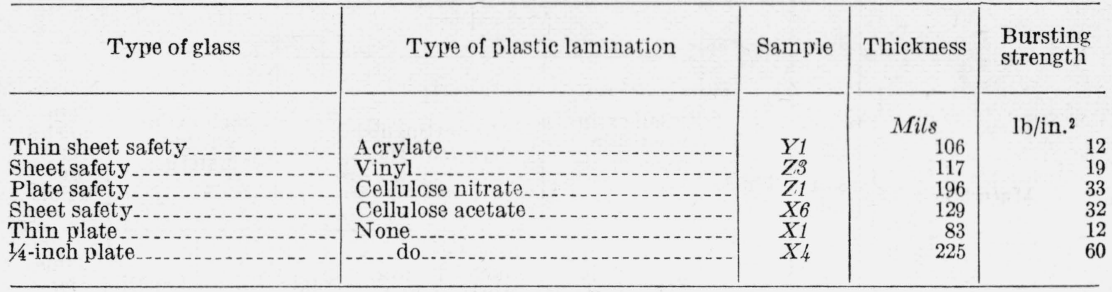

\section{FLAMMABILITY}

Two types of flammability tests for transparent plastic sheet were made on specimens 6 inches long and 0.5 inch wide. In one test, the specimen is suspended from a hook by a hole drilled $1 / 8$ inch from one end and an alcohol flame is kept in contact with the bottom edge for 10 seconds. The time required for the sample to fall from the hook or for the flame to be extinguished is noted. A proposed specification required that the sample shall not fall from the hook or become completely enveloped in flames in less than 40 seconds from the time the flame is applied. In the second test, the sample is clamped at one end in a horizontal position longitudinally and at an angle of $45^{\circ}$ to the horizontal laterally, ignited at the free end with an alcohol flame in contact with it for 10 seconds, and the time required to burn 3 inches or for the flame to be extinguished is determined. Army specification 9412014-A for transparent sheet requires that the time for the flame front to travel 3 inches shall be not less than $1 \frac{1}{2}$ minutes.

The results of these tests are shown in table 26 . It will be noted that for most of the materials two values are given. The first set of data was obtained after the specimens had been conditioned 24 to 48 hours at $21^{\circ} \mathrm{C}$ and 65 -percent relative humidity, whereas the second set of specimens had been in the conditioning room for approximately 30 days when tested.

The second set of samples in general tended to be extinguished more quickly or burn at a slightly slower rate than those conditioned for the shorter time. The cellulose acetate, cellulose acetobutyrate, vinyl chloride-acetate resin, glyceryl-phthalate resin, and phenol-formaldehyde resin samples passed the above requirements for both the horizontal and vertical tests. Some of the acrylate resin strips were enveloped in flames in less than the 40 seconds specified for the vertical test, but this is a very difficult value to estimate. Only one acrylate specimen burned faster than the rate of 2 inches per minute allowed for the horizontal test. One vinyl acetal resin and the ethylcellulose samples, all of which were relatively thin materials, burned in the horizontal test at a somewhat greater rate than the 2 inches per minute. However, none of these plastics was found to approach the degree of flammability of cellulose nitrate, which burned at a rate of about 17 inches per minute when held in a horizontal position. 
TABLE 26.-Flammability tests on transparent plastics ${ }^{a}$

\begin{tabular}{|c|c|c|c|c|c|c|c|c|c|c|}
\hline \multirow{3}{*}{ Material } & \multirow{3}{*}{$\begin{array}{l}\text { Sam- } \\
\text { ple }\end{array}$} & \multirow{3}{*}{$\begin{array}{l}\text { Thick- } \\
\text { ness }\end{array}$} & \multicolumn{5}{|c|}{ Vertical test } & \multicolumn{3}{|c|}{ Horizontal test } \\
\hline & & & \multicolumn{2}{|c|}{$\begin{array}{l}\text { Self-extin- } \\
\text { guishing } \\
\text { materials }\end{array}$} & \multicolumn{3}{|c|}{$\begin{array}{l}\text { Nonextinguishing: } \\
\text { materials }\end{array}$} & \multicolumn{2}{|c|}{$\begin{array}{l}\text { Self-extin- } \\
\text { guishing } \\
\text { materials }\end{array}$} & \multirow{2}{*}{$\begin{array}{c}\text { Nonex- } \\
\text { tin- } \\
\text { guish- } \\
\text { ing } \\
\text { ma- } \\
\text { terials } \\
\\
\begin{array}{c}\text { Time } \\
\text { for } \\
\text { burning } \\
3 \text { inches } \\
\text { of } \\
\text { sample }\end{array}\end{array}$} \\
\hline & & & $\begin{array}{l}\text { Burn- } \\
\text { ing } \\
\text { time of } \\
\text { sample }\end{array}$ & \begin{tabular}{|c|} 
Burn- \\
ing \\
time of \\
sample \\
and \\
drip- \\
pings
\end{tabular} & $\begin{array}{l}\text { Time at } \\
\text { which } \\
\text { sample } \\
\text { was en- } \\
\text { veloped } \\
\text { in } \\
\text { flames }\end{array}$ & $\begin{array}{c}\text { Time at } \\
\text { which } \\
\text { sample } \\
\text { fell off } \\
\text { hook }\end{array}$ & $\begin{array}{c}\text { Total } \\
\text { burning } \\
\text { time of } \\
\text { sample }\end{array}$ & $\begin{array}{l}\text { Burn- } \\
\text { ing } \\
\text { time of } \\
\text { sample }\end{array}$ & \begin{tabular}{|l|} 
Length \\
of \\
sample \\
burned
\end{tabular} & \\
\hline Cellulose acetate.- & $A 1$ & $\begin{array}{r}\text { Mils } \\
\quad 64\end{array}$ & $\left\{\begin{array}{r}\text { sec } \\
13 \\
11\end{array}\right.$ & $\begin{array}{c}\text { sec } \\
\end{array}$ & $\begin{array}{c}\text { sec } \\
\end{array}$ & $\begin{array}{c}\text { sec } \\
\end{array}$ & $\begin{array}{c}\text { sec } \\
\end{array}$ & $\begin{array}{c}\text { sec } \\
18 \\
11\end{array}$ & in. 0.6 & sec \\
\hline Do... & $A 2$ & 94 & & (n) & 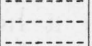 & & & 12 & 4 & (n) \\
\hline Do... & $A S$ & 131 & $\begin{array}{l}12 \\
11\end{array}$ & & & - n & & $\begin{array}{l}23 \\
14\end{array}$ & .4 & $\cdots$ \\
\hline Do..... & $B 1$ & 63 & $\begin{array}{l}16 \\
16\end{array}$ & 足 & & (n) & (n) & $\begin{array}{l}14 \\
24 \\
13\end{array}$ & $\begin{array}{r}.5 \\
.5\end{array}$ & - \\
\hline Do..... & $B 2$ & 94 & $\begin{array}{l}23 \\
24\end{array}$ & (n) & (n) & (n) & (n) & $\begin{array}{l}10 \\
38 \\
11\end{array}$ & & - \\
\hline Do & BS & 65 & $\begin{array}{l}19 \\
16\end{array}$ & 49 & (n) & (n) & (n) & 24 & .6 & (n) \\
\hline Do & B5 & 100 & & & 45 & 65 & 120 & & - & 237 \\
\hline Do.... & $B 13$ & 123 & $\left\{\begin{array}{l}40 \\
33\end{array}\right.$ & & +1 & - & -16 & 41 & 1. 0 & 190 \\
\hline Do... & $C 1$ & 54 & $\begin{array}{l}18 \\
26\end{array}$ & 41 & & & & $\begin{array}{l}23 \\
75\end{array}$ & $\begin{array}{l}0.7 \\
1.8\end{array}$ & - \\
\hline Do... & $C^{2}$ & 94 & $\begin{array}{l}30 \\
28\end{array}$ & 48 & 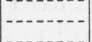 & (n) & $-\cdots$ & 89 & 1.2 & \\
\hline Do.... & $C 3$ & 124 & $\begin{array}{l}51 \\
40\end{array}$ & $\begin{array}{r}111 \\
84\end{array}$ & - & (n) & -...- & $\begin{array}{r}49 \\
147\end{array}$ & $\begin{array}{l}1.0 \\
2.1\end{array}$ & -..- \\
\hline Do..... & $D 1$ & 150 & -.... & & 80 & $\begin{array}{l}79 \\
82\end{array}$ & $\begin{array}{l}229 \\
169\end{array}$ & -n...... & 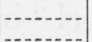 & $\begin{array}{l}171 \\
199\end{array}$ \\
\hline Cellulose acetobutyrate. & S1 & 40 & $\left\{\begin{array}{l}11 \\
14\end{array}\right.$ & 41 & & - n & & $\begin{array}{l}17 \\
18\end{array}$ & 0.8 & -... \\
\hline Cellulose nitrate & $E 1$ & 66 & & & 5 & 7 & & & & 8 \\
\hline Do... & $F 1$ & 63 & & & & $\begin{array}{l}7 \\
8\end{array}$ & & & & $\begin{array}{l}10 \\
12\end{array}$ \\
\hline Do.... & $W 1$ & 94 & & & 4 & $\begin{array}{l}10 \\
11\end{array}$ & - & $\cdots$ & & $\begin{array}{l}13 \\
11\end{array}$ \\
\hline Ethylcellulose_-. & G1 & 58 & & & 36 & $\begin{array}{l}39 \\
45\end{array}$ & $\begin{array}{l}49 \\
50\end{array}$ & & & $\begin{array}{l}60 \\
75\end{array}$ \\
\hline Do... & $H 1$ & 31 & & & 45 & $\begin{array}{l}40 \\
51\end{array}$ & (n) & 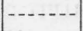 & $-\ldots$ & 49 \\
\hline Acrylate resin. & J2 & 80 & & & 36 & $\begin{array}{l}49 \\
54\end{array}$ & $\begin{array}{l}349 \\
319\end{array}$ & & & $\begin{array}{r}86 \\
118\end{array}$ \\
\hline Do & J3 & 135 & & & 42 & $\begin{array}{l}63 \\
68\end{array}$ & $\begin{array}{l}303 \\
373\end{array}$ & - n lo & -- & $\begin{array}{l}104 \\
109\end{array}$ \\
\hline Do & $K 1$ & 99 & & & & $\begin{array}{l}95 \\
63\end{array}$ & $\begin{array}{l}305 \\
250\end{array}$ & (n....... & & $\begin{array}{l}117 \\
117\end{array}$ \\
\hline Do $\ldots$ & $K_{2}$ & 88 & & & 35 & $\begin{array}{l}63 \\
59\end{array}$ & $\begin{array}{l}223 \\
276\end{array}$ & - & - & $\begin{array}{r}120 \\
93\end{array}$ \\
\hline Do & $K s$ & 61 & & & 28 & $\begin{array}{l}81 \\
51\end{array}$ & $\begin{array}{l}151 \\
142\end{array}$ & & & $\begin{array}{l}92 \\
96\end{array}$ \\
\hline Do & $K 6$ & 113 & & & & $\begin{array}{r}112 \\
81\end{array}$ & $\begin{array}{l}292 \\
237\end{array}$ & 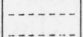 & & $\begin{array}{l}174 \\
140\end{array}$ \\
\hline $\begin{array}{l}\text { Vinyl chloride-acetate } \\
\text { resin }\end{array}$ & $L 2$ & 98 & (b) & $\left(b^{b}\right)$ & & & & $\left(b^{b}\right)$ & (b) & \\
\hline Vinyl acetal resin... & $N 1$ & 119 & & & 78 & $\begin{array}{l}64 \\
90\end{array}$ & $\begin{array}{l}136 \\
157\end{array}$ & & & $\begin{array}{l}118 \\
108\end{array}$ \\
\hline Do & N2 & 52 & & & & $\begin{array}{l}44 \\
68\end{array}$ & $\begin{array}{l}51 \\
78\end{array}$ & & & $\begin{array}{l}80 \\
77\end{array}$ \\
\hline Glyceryl-phthalate resin_. & 01 & 161 & & & $\left\{\begin{array}{l}-160 \\
-16\end{array}\right.$ & $\begin{array}{l}270 \\
230\end{array}$ & $\begin{array}{l}430 \\
423\end{array}$ & & & $\begin{array}{l}441 \\
282\end{array}$ \\
\hline $\begin{array}{l}\text { Phenol-formaldehyde } \\
\text { resin }\end{array}$ & $V 1$ & 260 & $\left({ }^{b}\right)$ & $\left({ }^{b}\right)$ & & & & $\left({ }^{b}\right)$ & $\left(b^{b}\right)$ & \\
\hline
\end{tabular}

a The first value for each material was obtained on a specimen conditioned 24 to 48 hours at $21^{\circ} \mathrm{C}$ and 65 percent relative humidity; the second value is for a specimen left for 30 days in the conditioning atmosphere before testing.

$\checkmark$ Would not ignite. 


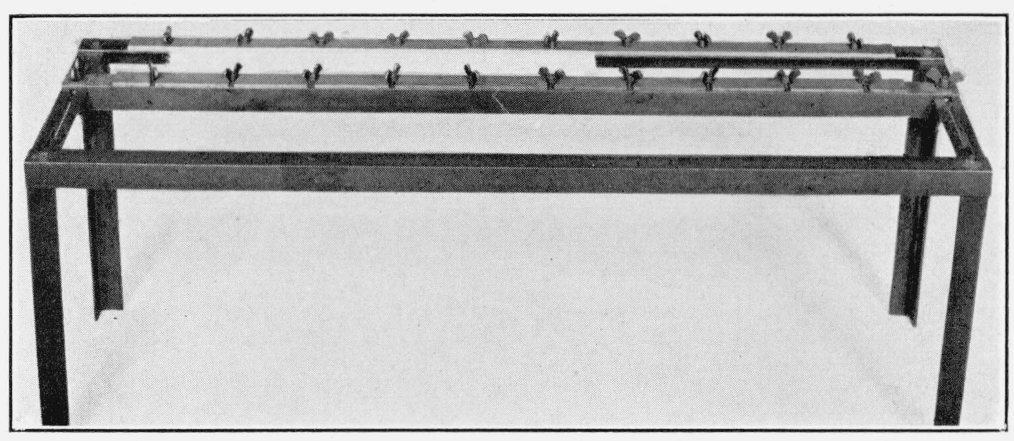

FiguRE 21.-Apparatus for determining rate of burning. 


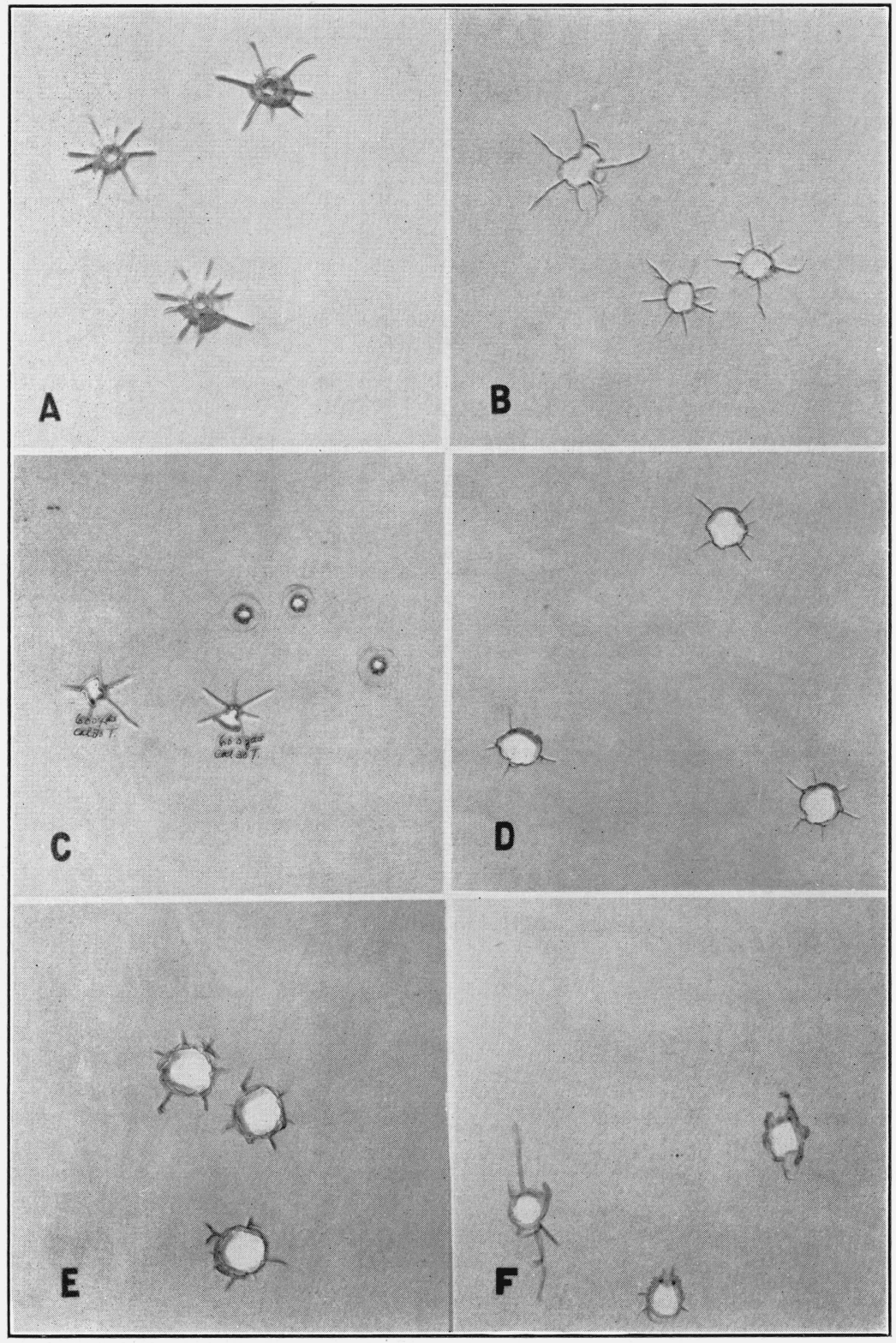

FIGURE 22.-Effect of tracer bullets on transparent plastics.

A. Acrylate resin, $K 1,0.113$ in. thick; three tracer bullets caliber .30 , M1, at 100 yards. $B$. Acrylate resin, $K 9,0.067$ in. thick; three tracer bullets caliber .50, M1, at 100 yards.

$C$. Cellulose nitrate, $F 1,0.062$ in. thick; three tracer bullets caliber .30, M1, at 100 yards; two tracer bullets caliber .30, M1, at 600 yards.

$D$. Cellut

E. Cellulose acetate, $C 2,0.095$ in. thick; three tracer bullets caliber .50, M1, at 100 yards.

$F$. Cellulose acetate, $B 3,0.066$ in. thick; three tracer bullets caliber .50, M1, at 100 yards. 


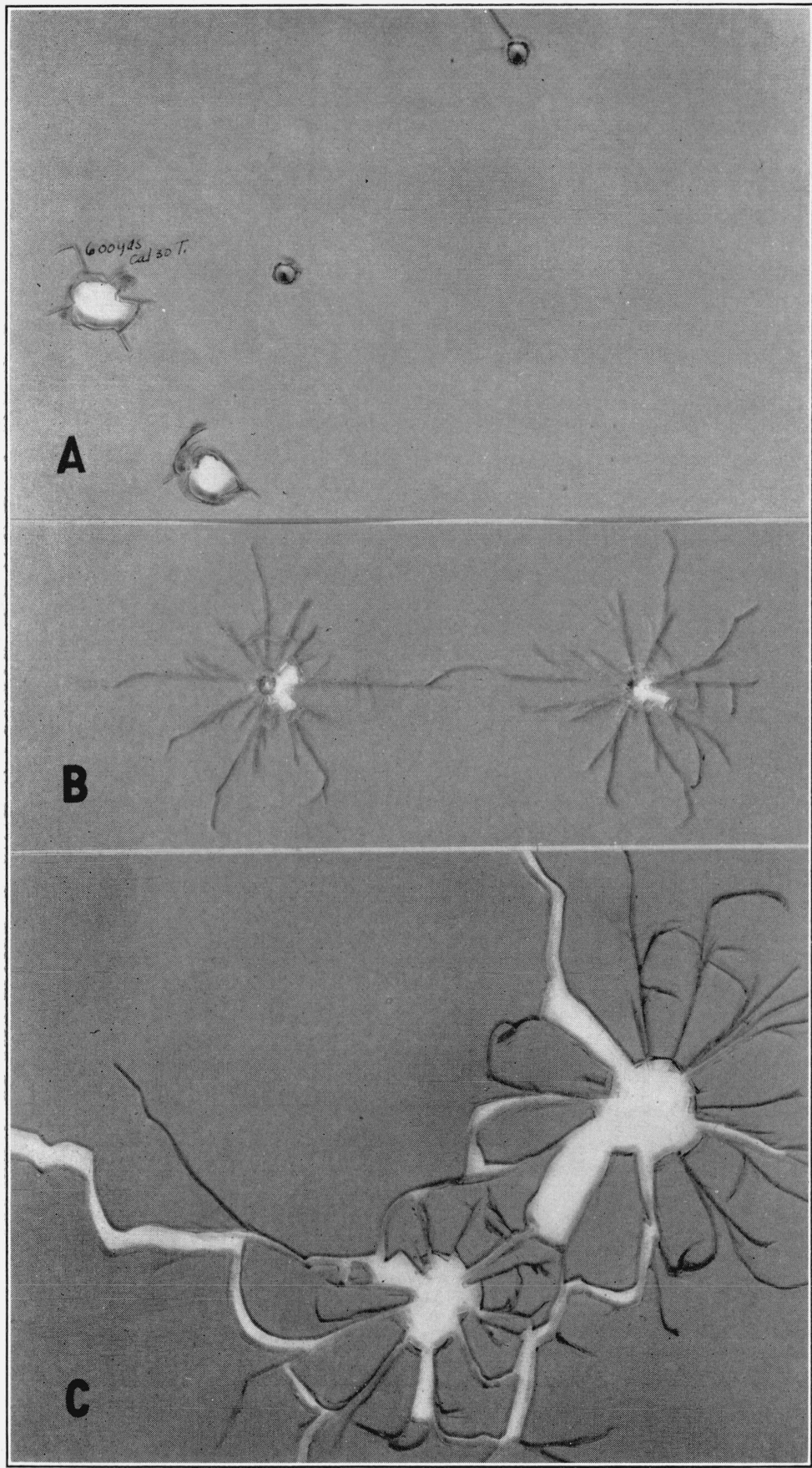

FigURE 23.-Effect of tracer bullets on transparent plastics.

A. Cellulose acetate, $A 2,0.095 \mathrm{in}$. thick; three tracer bullets caliber .30, M1, at 100 yards; one tracer bullet caliber.30, M1, at 600 yards.

$B$. Vinyl chloride-acetate resin, $L 3,0.100$ in. thick; two tracer bullets caliber . 30 , M1, at 100 yards

$C$. Vinyl chloride-acetate resin, $L 3,0.100 \mathrm{in}$. thick; two tracer bullets caliber .50, M1, at 100 yards. 


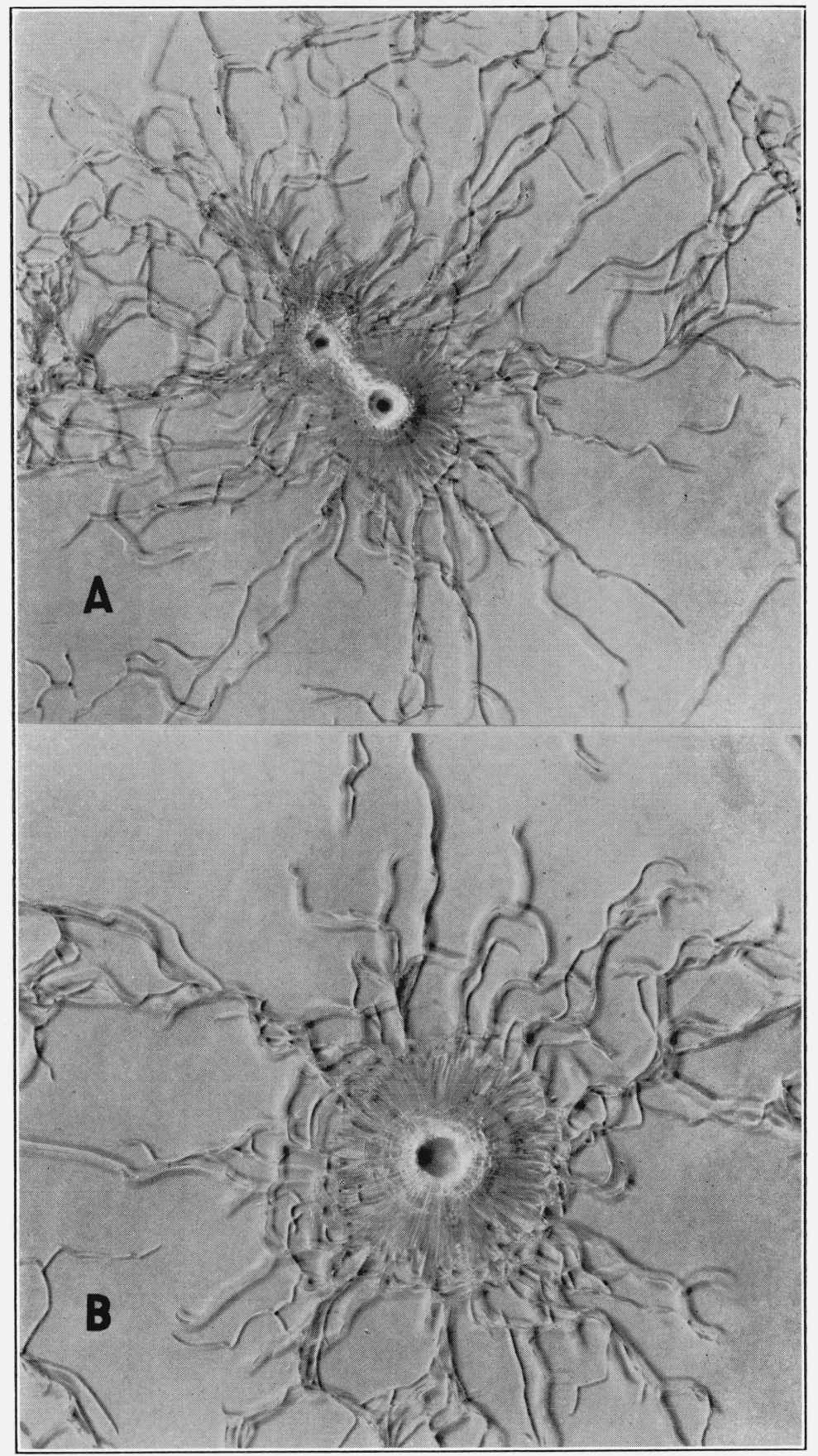

FiguRe 24.-Effect of tracer bullets on laminated glass.

A. Plate glass bonded with cellulose acetate plastic, X5, 0.188 inch thick; two tracer bullets caliber .30, M1, $B$. Plate and sheet glass bonded with acrylate resin plastic, $Y 5,0.238$ inch thick; one tracer bullet caliber .50 $\mathrm{M} 1$, at 100 yards. 
There is considerable question regarding the practical value of flammability tests of this type. The differences in ease of ignition or melting points greatly influence the results. Some samples tend to melt and separate the burning portion from the rest of the sample. The manner in which the strip is mounted for the test also is an important factor in the rate of burning. Data on the rates of burning in horizontal and vertical positions of plastics clamped in a metal frame (fig. 21) are presented in table 27. All the plastics including the cellulose nitrate burnt more slowly under these conditions. The cellulose acetate samples contained flame-retarding plasticizers which caused them to be extinguished in many of the tests shown in tables 26 and 27 . Sample B5, and apparently D1, did not contain this type of plasticizer.

TABLE 27.-Rate of burning of transparent plastics

\begin{tabular}{|c|c|c|c|c|c|c|c|}
\hline \multirow[b]{2}{*}{ Material } & \multirow[b]{2}{*}{ Sample } & \multicolumn{3}{|c|}{$\begin{array}{c}\text { Rate of burning of test strips } \\
3 / 4 \text { by } 3 \text { inch }\end{array}$} & \multicolumn{3}{|c|}{$\begin{array}{l}\text { Rate of burning of test strips } \\
11 / 4 \text { by } 3 \text { inch }\end{array}$} \\
\hline & & $\begin{array}{l}\text { Horizon- } \\
\text { tal strip } \\
\text { ignited at } \\
\text { one end }\end{array}$ & $\begin{array}{l}\text { Vertical } \\
\text { strip ig- } \\
\text { nited at } \\
\text { bottom }\end{array}$ & $\begin{array}{l}\text { Vertical } \\
\text { strip ig- } \\
\text { nited at } \\
\text { top }\end{array}$ & $\begin{array}{l}\text { Horizon- } \\
\text { tal strip } \\
\text { ignited at } \\
\text { one end }\end{array}$ & $\begin{array}{l}\text { Vertical } \\
\text { strip ig- } \\
\text { nited at } \\
\text { bottom }\end{array}$ & $\begin{array}{l}\text { Vertical } \\
\text { strip ig- } \\
\text { nited at } \\
\text { top }\end{array}$ \\
\hline $\begin{array}{l}\text { Cellulose acetate } \\
\text { Do }\end{array}$ & $\begin{array}{l}\text { C1 } \\
\text { Cs }\end{array}$ & $\begin{array}{r}\text { in. } / \min \\
0.93 \\
0.35\end{array}$ & $\begin{array}{l}\text { in./min } \\
\text { (a) } \\
\text { (a) }\end{array}$ & $\begin{array}{l}\text { in./min } \\
\text { (a) } \\
\text { (a) }\end{array}$ & in. $/ \min$ & in./min & in./min \\
\hline Cellulose nitrate & $\begin{array}{l}E 1 \\
F 1\end{array}$ & $\begin{array}{l}3.75 \\
3.96\end{array}$ & $\begin{array}{l}9.75 \\
8.55\end{array}$ & $\begin{array}{l}\text { 2. } 22 \\
2.12\end{array}$ & $\begin{array}{l}4.28 \\
5.00\end{array}$ & $\begin{array}{r}9.90 \\
10.30\end{array}$ & $\begin{array}{l}2.12 \\
2.08\end{array}$ \\
\hline Ethylcellulose.... & G1 & 1. 24 & 2.81 & 0.75 & 2.10 & 3.00 & 1. 25 \\
\hline $\begin{array}{l}\text { Acrylate resin } \\
\text { Do } \\
\text { Do }\end{array}$ & $\begin{array}{l}J 1 \\
J 2 \\
K 1\end{array}$ & $\begin{array}{r}0.41 \\
.28 \\
.21\end{array}$ & $\begin{array}{r}0.94 \\
.61 \\
.30\end{array}$ & $\begin{array}{l}.31 \\
.20 \\
.16\end{array}$ & $\begin{array}{r}0.52 \\
.51 \\
.31\end{array}$ & $\begin{array}{r}0.84 \\
.62 \\
.53\end{array}$ & $\begin{array}{r}0.31 \\
.23 \\
.18\end{array}$ \\
\hline Vinyl acetal resin .. & M1 & .53 & .88 & .29 & .83 & 1.41 & .38 \\
\hline Styrene resin & $R 1$ & .54 & .58 & .41 & & & \\
\hline
\end{tabular}

a Extinguished before burning 3 inches.

Tests made with incendiary bullets are of interest in connection with the establishment of specifications for the fire resistance of these materials. Tracer bullets of .30 and .50 caliber were fired through the samples at ranges of 100 and 600 yards. $^{2}$ None of the plastics, which included cellulose nitrate, cellulose acetate, vinyl chloride-acetate resin, and acrylate resin, was ignited. It is, therefore, apparent that, considered from the viewpoint of military requirements, the safe limits for the flammability of these materials should be based on storage and handling problems, which are serious only for the cellulose nitrate plastic, rather than on the danger of ignition from tracer bullets. The break caused by the impact of the bullet afforded useful information on the relative toughness of these materials. Some samples were merely penetrated by the bullets, which left small holes with no radial cracks, while others were completely shattered by the larger-caliber bullets. These effects of tracer bullets on transparent plastics are clearly shown in figures 22 and 23 . Figure 24 shows the type of break which is obtained when laminated glass made with cellulose acetate and acrylate resin plastics, respectively, are penetrated by tracer bullets. 


\section{CONCLUSION}

Pending the results of further tests on samples of cellulose acetate, acrylate resin, and other plastics, which have been prepared by the manufacturers using modified compositions and methods of processing to overcome the defective behavior noted during the course of this investigation, it is concluded that the problem of choosing between cellulose acetate and acrylate resin plastics for aircraft windows at present appears to be one of the required impact strength. If a relatively high impact strength is necessary, the cellulose acetate sheets are much superior to the acrylate resin in this respect. However, if high impact strength is not essential, then the superior clarity and weathering resistance of the acrylate resin makes it the more desirable material. Both the cellulose acetate and the acrylate resin have the advantages of being lighter in weight than glass and of being readily fitted to curved openings.

WaSHington, July 13, 1937. 